Prepared in cooperation with the College of Biological Sciences of the University of Minnesota and the Legislative-Citizen Commission on Minnesota Resources

\title{
Land-Cover Effects on the Fate and Transport of Surface-Applied Antibiotics and 17-beta-Estradiol on a Sandy Outwash Plain, Anoka County, Minnesota, 2008-09
}

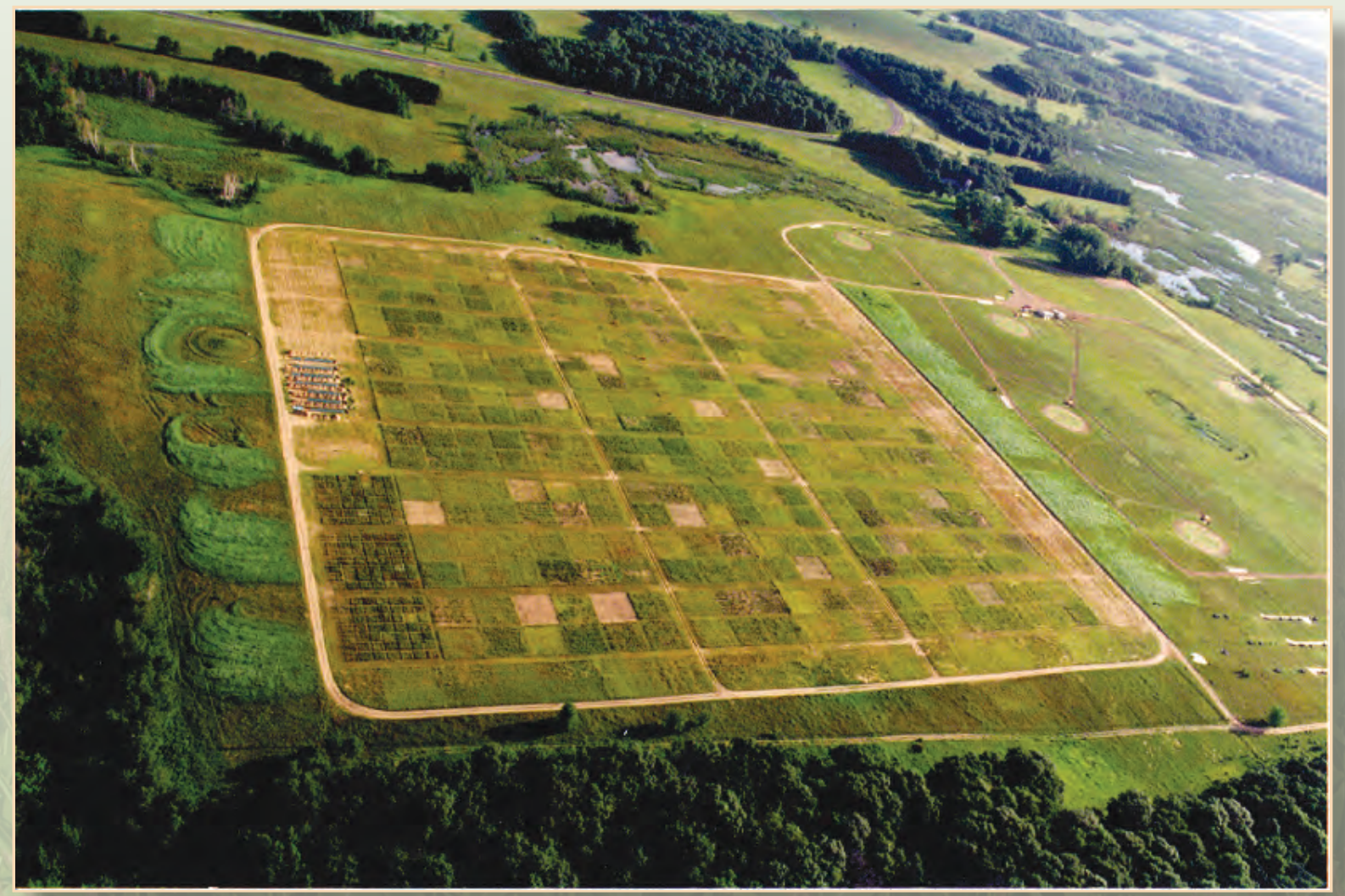

Scientific Investigations Report 2013-5202 
Cover. Experimental field plots at Cedar Creek Ecosystem Science Reserve, June 1997. Photograph by G. David Tilman. 


\section{Land-Cover Effects on the Fate and Transport of Surface-Applied Antibiotics and 17-beta-Estradiol on a Sandy Outwash Plain, Anoka County, Minnesota, 2008-09}

By Jared J. Trost, Richard L. Kiesling, Melinda L. Erickson, Peter J. Rose, and Sarah M. Elliott

Prepared in cooperation with the College of Biological Sciences of the University of Minnesota and the Legislative-Citizen Commission on Minnesota Resources

Scientific Investigations Report 2013-5202 


\title{
U.S. Department of the Interior SALLY JEWELL, Secretary
}

\section{U.S. Geological Survey Suzette M. Kimball, Acting Director}

\author{
U.S. Geological Survey, Reston, Virginia: 2013
}

For more information on the USGS - the Federal source for science about the Earth, its natural and living resources, natural hazards, and the environment, visit http://www.usgs.gov or call 1-888-ASK-USGS.

For an overview of USGS information products, including maps, imagery, and publications, visit http://www.usgs.gov/pubprod

To order this and other USGS information products, visit http://store.usgs.gov

Any use of trade, firm, or product names is for descriptive purposes only and does not imply endorsement by the U.S. Government.

Although this information product, for the most part, is in the public domain, it also may contain copyrighted materials as noted in the text. Permission to reproduce copyrighted items must be secured from the copyright owner.

Suggested citation:

Trost, J.J., Kiesling, R.L., Erickson, M.L., Rose, P.J., and Elliott, S.M., 2013, Land-cover effects on the fate and transport of surface-applied antibiotics and 17-beta-estradiol on a sandy outwash plain, Anoka County, Minnesota, 2008-09: U.S. Geological Survey Scientific Investigations Report 2013-5202, 51 p., http://dx.doi.org/sir20135202. 


\section{Acknowledgments}

This study was completed through the U.S. Geological Survey Cooperative Water Program in cooperation with the College of Biological Sciences of the University of Minnesota and the Legislative-Citizen Commission on Minnesota Resources. Partial financial support for this study was provided by the Minnesota Environment and Natural Resources Trust Fund as recommended by the Legislative-Citizen Commission on Minnesota Resources. The Trust Fund is a permanent fund institutionally established by the citizens of Minnesota to assist in the protection, conservation, preservation, and enhancement of the State's air, water, land, fish, wildlife, and other natural resources. Approximately 40 percent of net Minnesota State Lottery proceeds are dedicated to building the Trust Fund and ensuring future benefits for Minnesota's environment and natural resources.

The authors would like to thank Drs. Clarence Lehman and David Tilman in the Department of Ecology, Evolution, and Behavior at the University of Minnesota for providing insight into the experimental design and for granting access to a well-characterized environmental research facility. The authors would like to further acknowledge Dr. Lehman for all of the wisdom, patience, support, and guidance he provided throughout the entire study.

The authors would like to thank the staff of Cedar Creek Ecosystem Science Reserve, in particular Troy Mielke, Kally Worm, and Dan Bahauddin, for their assistance in coordinating the field aspects of the study and for providing historical data.

The authors would like to thank University of Minnesota technicians Jennifer Keville, Joy Degl'innocenti, Andrew Chua, Kritika Thapa, and Jason Williams for their assistance with field and laboratory data collection and management.

The authors would also like to thank several people from the U.S. Geological Survey who were essential to the study's success. Geoffrey Delin provided detailed guidance in the overall study scope, design, and implementation. Michael Meyer and Keith Loftin provided access to laboratory standards and equipment and trained team members in analytical chemistry methods. 


\section{Contents}

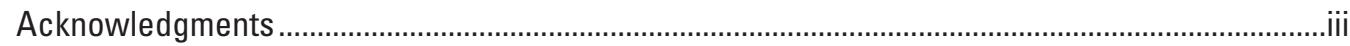

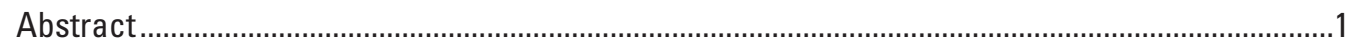

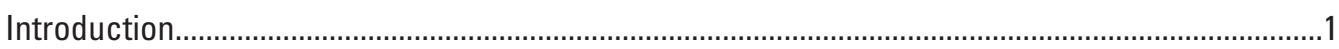

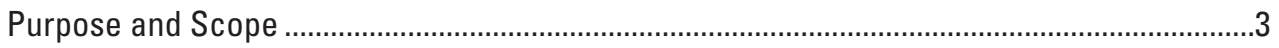

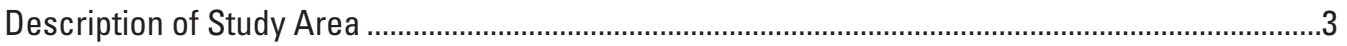

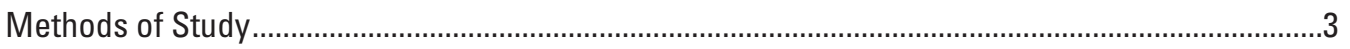

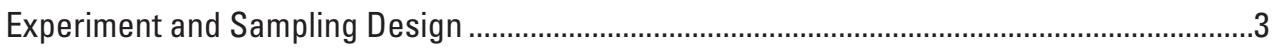

Establishment and Maintenance of Land-Cover Types......................................................

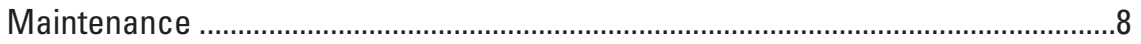

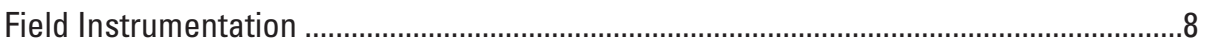

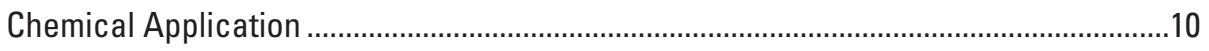

Collection and Storage of Field Samples ........................................................................11

Aboveground Plant Tissues and Root Biomass ..........................................................11

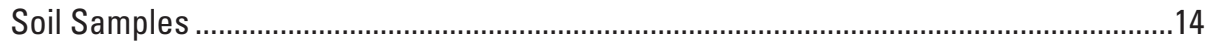

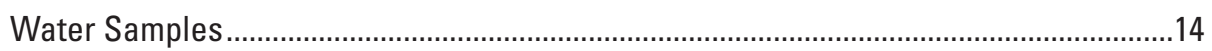

Laboratory Analytical Procedures ................................................................................15

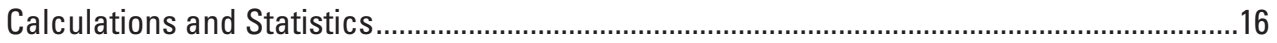

Precision and Accuracy of ELISA-Determined Concentrations .......................................16

Soil and Plant-Tissue Extractions ..............................................................................16

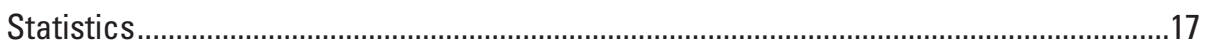

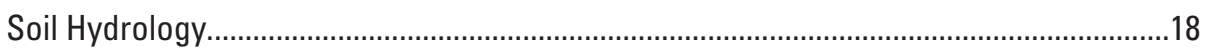

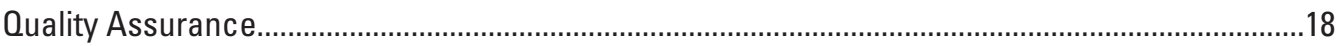

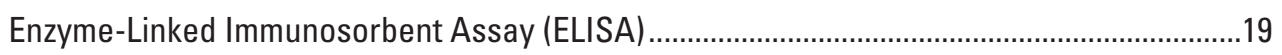

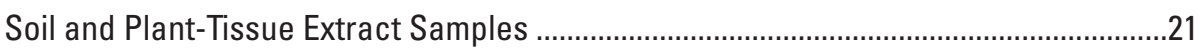

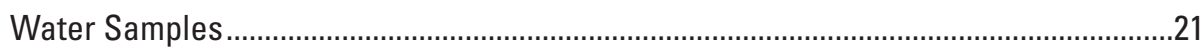

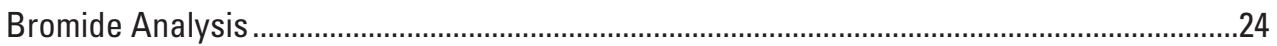

Land-Cover Effects on the Fate and Transport of Sulfamethazine, Sulfamethoxazole, and

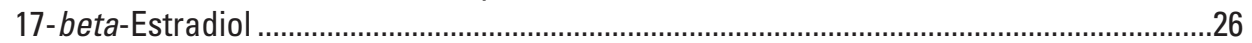

Sulfamethazine and Sulfamethoxazole ...........................................................................2

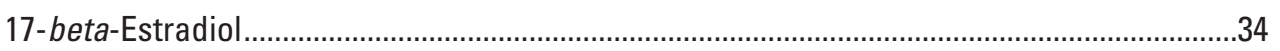

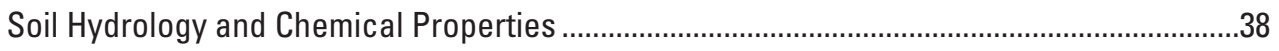

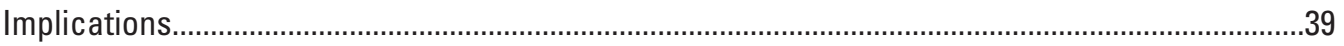

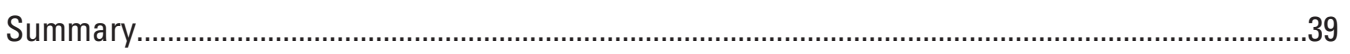

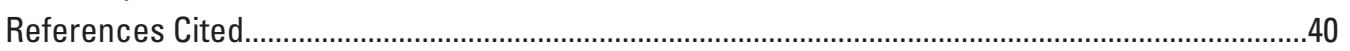

Appendix 1. Soil-Temperature and Soil-Water Content Data..........................................................46

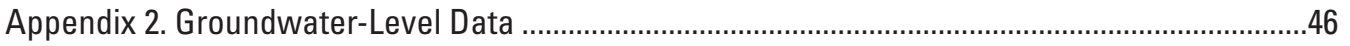

Appendix 3. Detailed Methods and Data for Sulfamethazine, Sulfamethoxazole, and

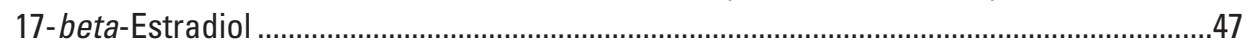

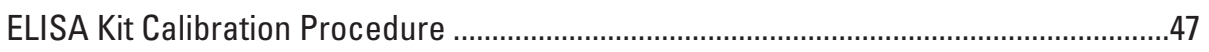

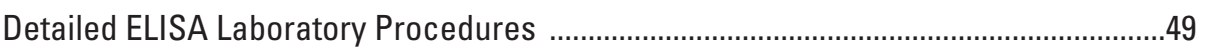

Appendix 4. Concentration Data ................................................................................................... 


\section{Figures}

1. Map showing location of Cedar Creek Ecosystem Science Reserve in east-central Minnesota and the approximate extent of the Anoka Sand Plain

2. Map showing layout of experimental field, land-surface topography, and regional groundwater-flow direction at Cedar Creek Ecosystem Science Reserve in east-central Minnesota ...

3. Cross-section diagram of sampling locations within the soil profile and field instrumentation used for measuring soil-water content, soil temperature, groundwater levels, and soil-water and groundwater quality

4. Boxplots of concentrations, measured with enzyme-linked immunosorbent assays, in blanks, calibration standards, and check standards for sulfamethazine, sulfamethoxazole, and 17-beta-estradiol

5. Graphs showing relation between coefficient of variation and mean concentration, grouped by sample medium, for replicate enzyme-linked immunosorbent assay determinations in all field and laboratory samples of sulfamethazine, sulfamethoxazole, and 17-beta-estradiol.

6. Boxplots of spike percent yield (recovery) in plant-tissue and soil extracts, spiked before extraction

7. Boxplots of the areal concentration in the upper 10 centimeters of soils in control and treatment plots for sulfamethazine in April 2009, SMZ in June 2009, sulfamethoxazole in April 2009, sulfamethoxazole in June 2009, 17-beta-estradiol in April 2009, and 17-beta-estradiol in June 2009.

8. Boxplots of the areal concentration in the upper 10 centimeters of soils between treatment plots grouped by land-cover type and control plots for sulfamethazine in April 2009, sulfamethazine in June 2009, sulfamethoxazole in April 2009, sulfamethoxazole in June 2009, 17-beta-estradiol in April 2009, and 17-beta-estradiol in June 2009

9. Boxplots of the change in areal concentration in the upper 10 centimeters of soils between April 2009 and June 2009 for sulfamethazine, sulfamethoxazole, and 17-beta-estradiol

10. Boxplots of fresh aboveground biomass harvested from research plots in June 2009, August 2009, and dry root biomass harvested from the upper 30 centimeters of soil in July 2009

11. Boxplots of the areal concentration in aboveground plant tissues

12. Boxplots of areal concentrations, as a percentage of the applied chemical, measured in treatment plots in the upper 10 centimeters of soil in April 2009 and June 2009 and in aboveground plant-tissue and soil samples in June 2009 and August 2009 for sulfamethazine, sulfamethoxazole, and 17-beta-estradiol. 


\section{Tables}

1. Research plot numbers, treatments, and installation details for groundwater wells and soil-water suction samplers at the Cedar Creek Ecosystem Science Reserve in east-central Minnesota.

2. Dates of chemical applications and soil-water, groundwater, soil, and plant-tissue sampling events for measurements of sulfamethoxazole, sulfamethazine, 17-beta-estradiol, and bromide

3. Chemical properties and the number of determinations of sulfamethoxazole, sulfamethazine, 17-beta-estradiol, and bromide in field samples and in field and sample processing blanks.

4. Concentrations of calibration standards and check standards used with enzyme-linked immunosorbent assay kits, and minimum reporting levels for plant-tissue, soil, and water samples for sulfamethazine, sulfamethoxazole, and 17-beta-estradiol.

5. Summary statistics of sulfamethazine, sulfamethoxazole, and 17-beta-estradiol concentrations measured in calibration standards, check standards, and blank quality-control samples

6. Summary statistics of percent yields (spike recoveries) of chemicals in known-addition spike samples for deionized water, citric acid extract buffer, plant-tissue extract, soil extract, soil-water, and groundwater samples spiked immediately prior to enzyme-linked immunosorbent assay analysis .....

7. Summary statistics of coefficient of variation determinations for sulfamethazine, sulfamethoxazole, and 17-beta-estradiol for calibration standards, check standards, spiked extract buffer, plant-tissue extract, soil extract, and water samples with mean concentrations greater than the minimum reporting level

8. Summary of Kruskal-Wallis rank sum test results for plant-tissue, soil, and root samples collected in 2009 at Cedar Creek Ecoystem Science Reserve, Minnesota ......28

9. Quality-assurance summary for bromide concentrations and water-quality characteristics in water samples analyzed at the U.S. Geological Survey National Water Quality Laboratory

10. Summary of detections of sulfamethazine, sulfamethoxazole, and 17-beta-estradiol in soil-water and groundwater samples collected from control and treatment plots of bare-soil, corn, hay, and prairie land-cover types. 


\section{Appendix Tables}

1-1. Descriptions of columns in table 1-3, which contains soil-temperature and volumetric soil-water content data for March 2008 through December 2009 . .46

1-2. Descriptions of codes used to describe the source of the soil-temperature and volumetric soil-water content data in table 1-3.

1-3. Continuous soil-temperature and volumetric soil-water content data from March 2008 through December 2009

2-1. Readme file for groundwater data presented in table 2-4 .............................................46

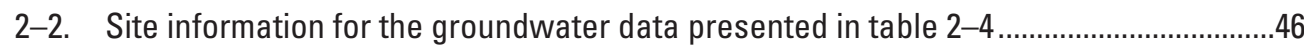

2-3. Descriptions of codes used to identify the source of the groundwater-level unit values in column Plot_254_AdjustedFeetBelowMP in table 2-4.

2-4. Groundwater data for two wells, in plot 254 and BG3, at Cedar Creek Ecosystem Science Reserve, east-central Minnesota.

4-1. Concentrations of sulfamethazine, sulfamethoxazole, and 17-beta-estradiol in plant-tissue, soil, soil-water, and groundwater samples analyzed with enzyme-linked immunosorbent assays

4-2. Concentrations of sulfamethazine, sulfamethoxazole, and 17-beta-estradiol in blank samples analyzed with enzyme-linked immunosorbent assays

4-3. Concentrations of bromide tracer in soil-water and groundwater samples analyzed at U.S. Geological Survey National Water Quality Laboratory using laboratory code 3166 or analyzed with a bromide ion-specific electrode

4-4. Concentrations of bromide tracer in soil-water and groundwater field and replicate samples analyzed at U.S. Geological Survey National Water Quality Laboratory using laboratory code 3166 or analyzed with a bromide ion-specific electrode

4-5. Concentrations of bromide tracer in blank and spike samples analyzed at U.S. Geological Survey National Water Quality Laboratory using laboratory code 3166 or analyzed with a bromide ion-specific electrode........ 


\section{Conversion Factors}

\begin{tabular}{|c|c|c|}
\hline Multiply & By & To obtain \\
\hline \multicolumn{3}{|c|}{ Length } \\
\hline centimeter $(\mathrm{cm})$ & 0.3937 & inch (in.) \\
\hline millimeter (mm) & 0.03937 & inch (in.) \\
\hline micron $(\mu \mathrm{m})$ & 0.00003937 & inch (in.) \\
\hline nanometer (nm) & 0.00000003927 & inch (in.) \\
\hline meter $(\mathrm{m})$ & 3.281 & foot (ft) \\
\hline kilometer (km) & 0.6214 & mile (mi) \\
\hline kilometer (km) & 0.5400 & mile, nautical (nmi) \\
\hline meter $(\mathrm{m})$ & 1.094 & yard (yd) \\
\hline \multicolumn{3}{|c|}{ Area } \\
\hline square meter $\left(\mathrm{m}^{2}\right)$ & 0.0002471 & acre \\
\hline hectare (ha) & 2.471 & acre \\
\hline square meter $\left(\mathrm{m}^{2}\right)$ & 10.76 & square foot $\left(\mathrm{ft}^{2}\right)$ \\
\hline square centimeter $\left(\mathrm{cm}^{2}\right)$ & 0.1550 & square inch $\left(\mathrm{ft}^{2}\right)$ \\
\hline \multicolumn{3}{|c|}{ Volume } \\
\hline liter (L) & 33.82 & ounce, fluid (fl. oz) \\
\hline liter (L) & 2.113 & $\operatorname{pint}(\mathrm{pt})$ \\
\hline liter (L) & 1.057 & quart (qt) \\
\hline liter (L) & 0.2642 & gallon (gal) \\
\hline liter (L) & 61.02 & cubic inch $\left(\right.$ in $\left.^{3}\right)$ \\
\hline milliliter $(\mathrm{mL})$ & 0.03382 & ounce, fluid (fl. oz) \\
\hline microliter $(\mu \mathrm{L})$ & 0.00003382 & ounce, fluid (fl. oz) \\
\hline \multicolumn{3}{|c|}{ Flow rate } \\
\hline liter per minute $(\mathrm{L} / \mathrm{min})$ & 0.2642 & gallon per minute (gal/min) \\
\hline \multicolumn{3}{|c|}{ Mass } \\
\hline nanogram (ng) & 0.00000000003527 & ounce, avoirdupois (oz) \\
\hline milligram (mg) & 0.00003527 & ounce, avoirdupois (oz) \\
\hline $\operatorname{gram}(\mathrm{g})$ & 0.03527 & ounce, avoirdupois (oz) \\
\hline kilogram (kg) & 2.205 & pound avoirdupois (lb) \\
\hline ton $(\mathrm{t})$ & 2,000 & pound avoirdupois (lb) \\
\hline \multicolumn{3}{|c|}{ Pressure } \\
\hline kilopascal (kPa) & 0.009869 & atmosphere, standard (atm) \\
\hline kilopascal (kPa) & 0.01 & bar \\
\hline kilopascal (kPa) & 0.2961 & inch of mercury at $60^{\circ} \mathrm{F}$ (in $\mathrm{Hg}$ ) \\
\hline \multicolumn{3}{|c|}{ Density } \\
\hline gram per cubic centimeter $\left(\mathrm{g} / \mathrm{cm}^{3}\right)$ & 62.4220 & pound per cubic foot $\left(\mathrm{lb} / \mathrm{ft}^{3}\right)$ \\
\hline \multicolumn{3}{|c|}{ Application rate } \\
\hline kilograms per hectare (kg/ha) & 0.8921 & pounds per acre (lb/acre) \\
\hline liters per hectare (L/ha) & 0.1069 & gallons per acre (gal/acre) \\
\hline grams per square meter $\left(\mathrm{g} / \mathrm{m}^{2}\right)$ & 0.02048 & pounds per square foot $\left(\mathrm{lb} / \mathrm{ft}^{2}\right)$ \\
\hline milligrams per square meter $\left(\mathrm{mg} / \mathrm{m}^{2}\right)$ & 0.00002048 & pounds per square foot $\left(\mathrm{lb} / \mathrm{ft}^{2}\right)$ \\
\hline
\end{tabular}


Temperature in degrees Celsius $\left({ }^{\circ} \mathrm{C}\right)$ may be converted to degrees Fahrenheit $\left({ }^{\circ} \mathrm{F}\right)$ as follows:

${ }^{\circ} \mathrm{F}=\left(1.8 \times^{\circ} \mathrm{C}\right)+32$

Vertical coordinate information is referenced to the National Geodetic Vertical Datum of 1929 (NGVD 29).

Horizontal coordinate information is referenced to the North American Datum of 1983 (NAD 83).

Altitude, as used in this report, refers to distance above the vertical datum.

Specific conductance is given in microsiemens per centimeter at 25 degrees Celsius $(\mu \mathrm{S} / \mathrm{cm}$ at $\left.25^{\circ} \mathrm{C}\right)$.

Concentrations of chemical constituents in water are given either in milligrams per liter ( $\mathrm{mg} / \mathrm{L}$ ), micrograms per liter $(\mu \mathrm{g} / \mathrm{L})$, or nanograms per liter $(\mathrm{ng} / \mathrm{L})$, which are equivalent to parts per million (ppm), parts per billion (ppb), and parts per trillion (ppt), respectively. Concentrations of chemicals in plant-tissue and soil extracts are given in nanograms per gram $(\mathrm{ng} / \mathrm{g})$, which is equivalent to parts per billion (ppb). Concentrations of chemical constituents in methanol are given in either grams per liter ( $\mathrm{g} / \mathrm{L}$ ) or milligrams per liter (mg/L). 


\section{Abbreviations}

$\begin{array}{ll}> & \text { greater than } \\ < & \text { less than } \\ \pm & \text { plus or minus } \\ \text { B } & \text { registered trademark } \\ \text { TM } & \text { trademark } \\ \text { 17BE } & \text { 17-beta-estradiol } \\ A_{r} & \text { relative percent absorbance } \\ \mathrm{C}_{4} & \text { carbon fixation pathway in warm season grasses } \\ \text { CCESR } & \text { Cedar Creek Ecosystem Science Reserve } \\ \left.\text { CO(NH }{ }_{2}\right)_{2} & \text { urea } \\ \text { CRP } & \text { Conservation Reserve Program } \\ \text { CV } & \text { coefficient of variation } \\ \text { ELISA } & \text { enzyme-linked immunosorbent assay } \\ \text { ET } & \text { evapotranspiration } \\ \text { HSD } & \text { Tukey Honest Significant Difference } \\ \text { KBr } & \text { potassium bromide } \\ \mathrm{K}_{\text {ow }} & \text { octanol-water partition coefficient } \\ \text { LC/MS } & \text { liquid chromatography/mass spectrometry } \\ \text { LLC } & \text { limited liability company } \\ \text { M } & \text { molar } \\ \text { MRL } & \text { minimum reporting level } \\ \text { NaOH } & \text { sodium hydroxide } \\ \text { NWIS } & \text { National Water Information System } \\ \text { PTFE } & \text { polytetrafluoroethylene } \\ \text { PVC } & \text { polyvinyl chloride } \\ \text { RWT } & \text { rhodamine WT } \\ \text { SMX } & \text { sulfamethoxazole } \\ \text { SMZ } & \text { sulfamethazine } \\ \text { TDR } & \text { time domain reflectometry } \\ \text { USGS } & \text { U.S. Geological Survey } \\ \text { VOA } & \text { volatile organic analysis } \\ & \end{array}$




\title{
Land-Cover Effects on the Fate and Transport of Surface- Applied Antibiotics and 17-beta-Estradiol on a Sandy Outwash Plain, Anoka County, Minnesota, 2008-09
}

\author{
By Jared J. Trost, ${ }^{1}$ Richard L. Kiesling, ${ }^{1}$ Melinda L. Erickson, ${ }^{1}$ Peter J. Rose, ${ }^{2}$ and Sarah M. Elliott ${ }^{1}$
}

\section{Abstract}

A plot-scale field experiment on a sandy outwash plain in Anoka County in east-central Minnesota was used to investigate the fate and transport of two antibiotics, sulfamethazine (SMZ) and sulfamethoxazole (SMX), and a hormone, 17-betaestradiol (17BE), in four land-cover types: bare soil, corn, hay, and prairie. The SMZ, SMX, and 17BE were applied to the surface of five plots of each land-cover type in May 2008 and again in April 2009. The cumulative application rate was 16.8 milligrams per square meter $\left(\mathrm{mg} / \mathrm{m}^{2}\right)$ for each antibiotic and $0.6 \mathrm{mg} / \mathrm{m}^{2}$ for $17 \mathrm{BE}$. Concentrations of each chemical in plant-tissue, soil, soil-water, and groundwater samples were determined by using enzyme-linked immunosorbent assay (ELISA) kits. Soil-water and groundwater sampling events were scheduled to capture the transport of SMZ, SMX, and 17BE during two growing seasons. Soil and plant-tissue sampling events were scheduled to identify the fate of the parent chemicals of SMZ, SMX, and 17BE in these matrices after two chemical applications. Areal concentrations $\left(\mathrm{mg} / \mathrm{m}^{2}\right)$ of SMZ and SMX in soil tended to decrease in prairie plots in the 8 weeks after the second chemical application, from April 2009 to June 2009, but not in other land-cover types. During these same 8 weeks, prairie plots produced more aboveground biomass and had extracted more water from the upper 125 centimeters of the soil profile compared to all other land-cover types. Areal concentrations of SMZ and SMX in prairie plant tissue did not explain the temporal changes in areal concentrations of these chemicals in soil. The areal concentrations of SMZ and SMX in the aboveground plant tissues in June 2009 and August 2009 were much lower, generally two to three orders of magnitude, than the areal concentrations of these chemicals in soil. Pooling all treatment plot data, the median areal concentration of SMZ and SMX in plant tissues was 0.01 and 0.10 percent of the applied chemical mass compared to 22 and 12 percent in soil, respectively. Furthermore, areal concentrations of SMZ and SMX in plant-tissue samples

\footnotetext{
${ }^{1}$ U.S. Geological Survey.
}

${ }^{2}$ Bureau of Ocean Energy Management. were variable, and did not differ significantly between control and treatment plots within each land-cover type.

SMZ was detected in 23 percent of soil-water samples and in 16 percent of groundwater samples collected between October 2008 and October 2009 in treatment plots, indicating that surface-applied SMZ leached below the rooting zone and reached groundwater. SMX was detected in only 1 percent of soil-water and groundwater samples during this same time period. In contrast to the antibiotics, $17 \mathrm{BE}$ was not reliably detected in soil samples. Additionally, ELISA-determined 17BE concentrations in plant-tissue, soil-water, and groundwater samples indicated the presence of chemicals that were not applied as part of this experiment [17BE from an external source or other chemical(s) that interfered with the $17 \mathrm{BE}$ ELISA kits].

\section{Introduction}

Chemicals of emerging concern are a broad class of anthropogenic or naturally occurring organic compounds present in the environment but usually are not routinely monitored and do not have regulatory limits. Examples of these chemicals include antibiotics and other pharmaceuticals, hormones, personal-care products, fire retardants, pesticides, and detergents (Kolpin and Furlong, 2002). A growing body of research documents the presence of these chemicals in surface water (Kolpin, 1997; Campagnolo and others, 2002; Kolpin and others, 2002; Lee and others, 2004) and groundwater (Kolpin, 1997; Kolpin and others, 2001; Worrall and others, 2002; Lee and others, 2004; Hamscher and others, 2005; Erickson, 2012). As these chemicals move through the environment, they have the potential to cause biological disruptions, such as antibiotic resistance (Levy, 1998; Iwane and others, 2001; Kummerer, 2004a) and endocrine disruption (Crisp and others, 1998). These chemicals are introduced to the environment from a variety of sources including agriculture, municipal wastewater-treatment facilities, and individual septic treatment systems (Tolls, 2001; Thiele-Bruhn, 2003; Swartz and others, 2006). Chemicals of emerging concern examined 
in this report are two antibiotics, sulfamethazine (SMZ) and sulfamethoxazole (SMX), and the steroidal hormone 17-beta-estradiol (17BE).

Modern row-crop methods of food and energy production release chemicals of emerging concern, such as SMZ and $17 \mathrm{BE}$, to the environment and may reduce the quality of food for livestock and human consumption (Boxall and others, 2003). Spreading liquid manure from animal feedlots on agricultural fields is a common practice for disposing of animal manure. Runoff water and water leaching from agricultural fields and manure stockpiles have been determined to contain antibiotics (Kay and others, 2005; Dolliver and Gupta, 2008a, 2008b). Veterinary pharmaceutical chemicals have been detected in manure (Tolls, 2001; DeLiguoro and others, 2003), soils (Tolls, 2001; Thiele-Bruhn, 2003; Kay and others, 2004), surface waters (Kolpin and others, 2002), and groundwater (Hamscher and others, 2005).

The antibiotic SMZ commonly is used in animal agriculture for disease management or to improve growth efficiency (Dolliver and others, 2007). Before 2001, an estimated 400 tons of SMZ was used annually in the United States as a feed additive for cattle and swine production (Mellon and others, 2001). SMZ persists in soils receiving manure and leaches through the soil column to groundwater (Hamscher and others, 2005). In a national survey of surface waters susceptible to contamination, SMZ was detected in 5 percent of stream samples (Kolpin and others, 2002).

The antibiotic SMX commonly is prescribed for the treatment of urinary tract infections in humans (Huang and Stafford, 2002). Approximately 15 percent of ingested SMX is excreted from the human body in its original form (Hirsch and others, 1999). Monitoring data on raw and treated sewage from municipal wastewater-treatment plants indicates that sulfonamide antibiotics, such as SMX, persist through the sewage treatment process (Hartig and others, 1999). In a national survey of surface waters susceptible to contamination, SMX was detected in 19 percent of stream samples (Kolpin and others, 2002). Near Helena, Montana, an area with a growing number of septic tank and drainfield systems, SMX was detected in 80 percent of groundwater samples (Miller and Meek, 2006).

The steroidal hormone $17 \mathrm{BE}$ is a mammalian hormone that is associated with high population densities of female mammals, as is common in pork, beef, and dairy production (Hanselman and others, 2003). Kolpin and others (2002), in a national survey of surface waters susceptible to contamination, documented $17 \mathrm{BE}$ in 10 percent of samples. The hormone $17 \mathrm{BE}$ also has been determined to be mobilized in the pore water of soils amended with manure in response to precipitation events (Kjaer and others, 2007; Casey and others, 2008; Thompson and others, 2009; Schuh and others, 2011).

Because these three chemicals (SMZ, SMX, and 17BE) commonly reach the environment and have the potential to cause antibiotic resistance and endocrine disruption, it is important to develop management practices to reduce their prevalence beyond the sources. One strategy is to intersect agricultural or human waste streams with perennial bioenergy crops, such as prairie. Prairies comprising diverse mixtures of grasses, forbs, shrubs, and legumes possess properties that have been determined to provide beneficial water-quality improvements (Dijkstra and others, 2007) and a source of sustainable energy (Tilman, Hill, and Lehman, 2006). Prairies produce perennial aboveground vegetation and deep, dense root systems that improve water quality and restore hydrologic pathways without needing continual application of pesticides and fertilizers (Brye and others, 2000; Tilman, Hill, and Lehman, 2006). Prairies are more effective than row crops at reducing overland flow and downward flux of water through soils to groundwater, allowing for the interception of nutrients, pesticides, and other chemicals (Randall and others, 1997; Brye and others, 2000; Weber and others, 2001; Tilman, Hill, and Lehman, 2006; Dijkstra and others, 2007). Furthermore, when aboveground prairie biomass is annually harvested for bioenergy, the net energy produced is similar to that of corn grain ethanol with the additional benefit of a net reduction in atmospheric carbon dioxide (Tilman, Hill, and Lehman, 2006).

Determining the effects of land-cover types on the fate and transport of surface-applied chemicals requires detailed information on the chemicals as they are sequestered in soil, degraded, taken up by plants, and transported through soil to groundwater. Several studies have examined the fate and transport of many chemicals of emerging concern through soils, as reviewed in Tolls (2001) and Thiele-Bruhn (2003), but little is known about the fate of antibiotics in soils (ThieleBruhn, 2003). Few studies have focused on the ability of plants to take up antibiotics (Boxall and others, 2006). Prairie systems have the potential for substantially greater chemical uptake than annually harvested row crops because most of the biomass of a prairie is below ground (Fornara and Tilman, 2008) and prairie plants actively take up water throughout the entire growing season (Brye and others, 2000; Trost, 2010). Prairies also affect soil properties, including soil carbon content (Tilman, Hill, and Lehman, 2006; Fornara and Tilman, 2008), which is important in controlling the sorption of these chemicals on solids (Lai and others, 2000; Kummerer, 2004b). Process-based studies on the movement and persistence of antibiotics and other chemicals of emerging concern through different land-cover types are necessary to determine the fate of these chemicals in the environment.

The U.S. Geological Survey (USGS), in cooperation with the College of Biological Sciences of the University of Minnesota and the Legislative-Citizen Commission on Minnesota Resources, completed a plot-scale field experiment on a sandy outwash plain in Anoka County in east-central Minnesota (fig. 1) to determine the effects of land-cover type on the fate and transport of surface-applied SMZ, SMX, and 17BE in four land-cover types: bare soil, corn, hay, and prairie. The three chemicals were applied to the surface of five plots of each land-cover type in May 2008 and April 2009. Concentrations of each chemical in plant-tissue, soil, soilwater, and groundwater samples were determined by using enzyme-linked immunosorbent assay (ELISA) kits purchased from Abraxis, LLC (Warminster, Pennsylvania). The ELISA 
methodology is an analytical technology that has been successfully used for assessing the presence of some chemicals of emerging concern in a variety of environmental sample matrices (Aga and others, 2003; Kumar and others, 2004; Dolliver, Gupta, and Noll, 2008; Dolliver, Kumar, and others, 2008; Dolliver and Gupta, 2008a, 2008b).

\section{Purpose and Scope}

The purpose of this report is to describe the land-cover effects on the fate and transport of surface-applied sulfamethazine (SMZ), sulfamethoxazole (SMX), and 17-beta-estradiol (17BE) on a sandy outwash plain in Anoka County, Minnesota (fig. 1). The types of land cover considered were bare soil and three biofuel cropping systems: corn, hay, and prairie. Concentrations of these chemicals were determined in plant-tissue, soil, soil-water, and groundwater samples collected from a plot-scale field experiment between October 2008 and October 2009.

\section{Description of Study Area}

This study was done at the Cedar Creek Ecosystem Science Reserve (CCESR), a University of Minnesota research station in Anoka and Isanti Counties, Minn. (fig. 1). The CCESR is situated on the eastern one-third of the Anoka Sand Plain (fig. 1), a nutrient-poor sandy glacial outwash plain (Typic Udipsamment soil) (Grigal and others, 1974). The surficial sediments at CCESR predominantly are very fine to fine sand with distinct textural variations evident in the subsurface (Grigal and others, 1974). The upper surface of the unconfined surficial aquifer of the Anoka Sand Plain lies near land surface, with many lakes, streams, and wetlands being expressions of the water table (Lindholm, 1980). Mean annual precipitation is 79.6 centimeters $(\mathrm{cm})$, of which $14 \mathrm{~cm}$ fall as snow (Natural Resources Conservation Service, 2010). Mean monthly temperatures range from -11 degrees Celsius $\left({ }^{\circ} \mathrm{C}\right)$ in January to $22^{\circ} \mathrm{C}$ in July (Natural Resources Conservation Service, 2010). Mean annual potential evapotranspiration is estimated to be $60 \mathrm{~cm}$ from empirical calculations (Baker, 1958).

A 35-plot subset of several hundred research plots originally planted in 1994 with varying levels of biodiversity (Cedar Creek Ecosystem Science Reserve, 2012a; Tilman, Reich, and Knops, 2006) was used in this field experiment. Candidate plots for this experiment were selected based on two criteria: (1) the plots originally were planted with eight prairie plant species in 1994 and (2) the plant cover in June 2007 primarily consisted (greater than 50 percent) of native warm-season $\left(\mathrm{C}_{4}\right)$ grasses and leguminous forbs (Raven and others, 1999). After all candidate plots were identified, experimental treatments for this study were randomly assigned to 35 of those plots.

\section{Methods of Study}

This section of the report describes the field experiment and sampling design, the collection and storage of field samples, and laboratory analytical procedures used in this study. The methods used for calculations and statistics also are described.

\section{Experiment and Sampling Design}

The experimental design included 35 plots, each measuring 11 meters $(\mathrm{m})$ by $11 \mathrm{~m}$, with land-cover types of nonvegetative bare soil, corn, hay, or prairie (fig. 2; table 1). Five "treatment" plots of each land-cover type (20 plots total) received surface applications of sulfamethazine (SMZ), sulfamethoxazole (SMX), 17-beta-estradiol (17BE), and hydrologic tracers (bromide and rhodamine WT). Background concentrations of SMZ, SMX, and 17BE in plant tissues, soil, soil water, and groundwater were determined in samples collected from bare soil, hay, and prairie "control" plots (15 plots total) that did not receive any chemical applications. Background concentrations of SMZ, SMX, and 17BE in corn plants were determined in samples collected from a single large stand of corn that did not receive additions of these chemicals (fig. 2). Sampling events were scheduled to (1) capture the transport of SMZ, SMX, 17BE, and bromide in soil water and groundwater and (2) identify the fate of SMZ, SMX, and 17BE (not metabolites) in plant tissues and soils after two applications of these chemicals.

Degradation of the surface-applied SMZ, SMX, and 17BE by soil microbes, sunlight, or other processes also likely affected the fate and transport of these chemicals during the experiment (Boxall and others, 2004); however, measurements of degradation and metabolites were beyond the scope of this experiment. All three chemicals, SMZ, SMX, and 17BE, have been detected in the environment beyond the site of original use (for example, Kolpin and others, 2002). These observations demonstrate the persistence of each parent chemical and the importance of understanding their fate and transport.

\section{Establishment and Maintenance of Land-Cover Types}

This section describes the establishment and maintenance of the land-cover types used in this experimental study. The 35 research plots for the four land-cover types used in this study are shown in figure 2 .

To establish the bare soil plots, the existing prairie vegetation was sprayed with glyphosate, mowed, and removed by raking from August through September in 2007. The bare soil treatment was maintained by spraying any emergent vegetation with glyphosate every 2 to 4 weeks from May through October in 2008 and 2009. 


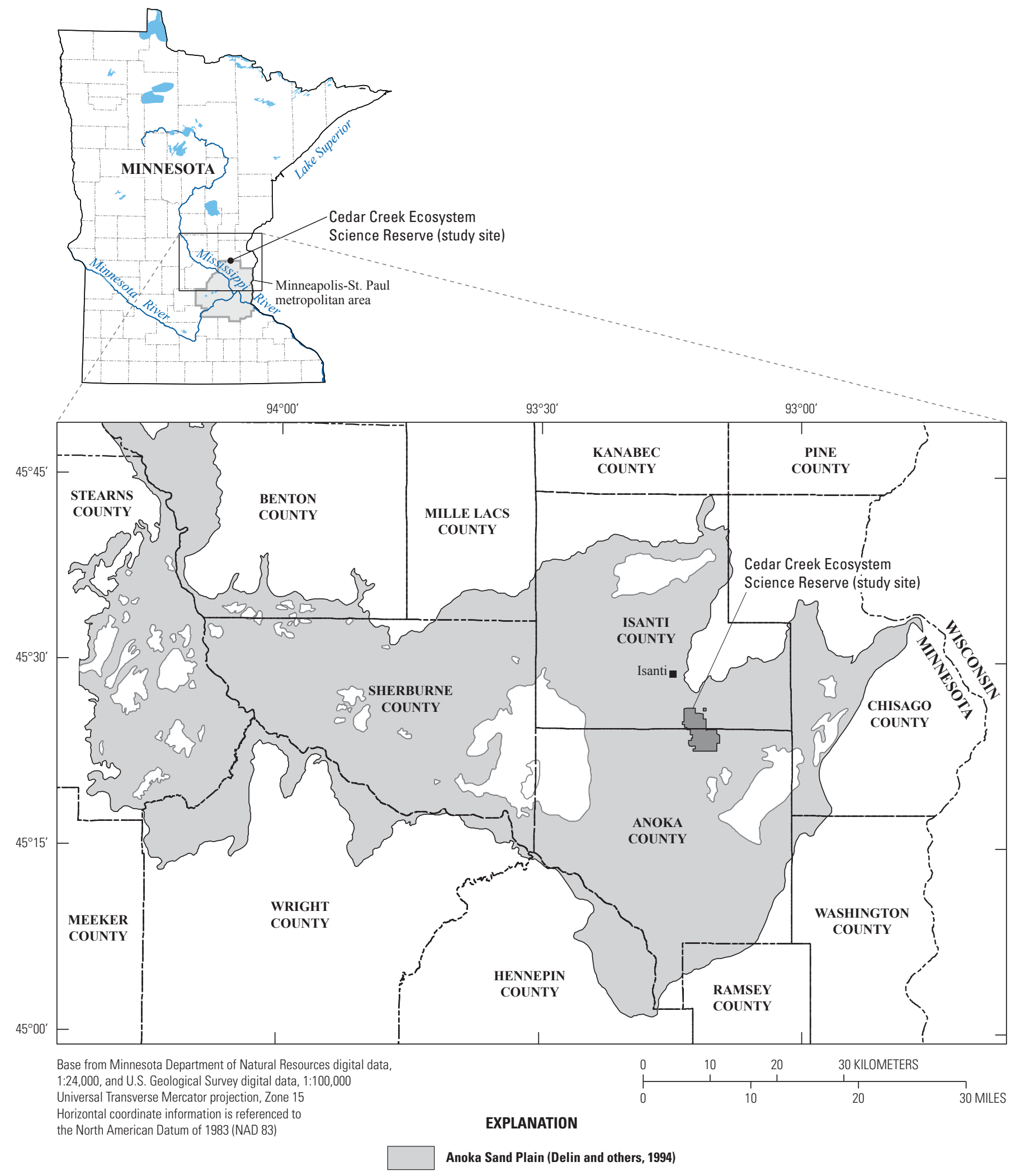

Figure 1. Location of Cedar Creek Ecosystem Science Reserve (CCESR) in east-central Minnesota and the approximate extent of the Anoka Sand Plain. 


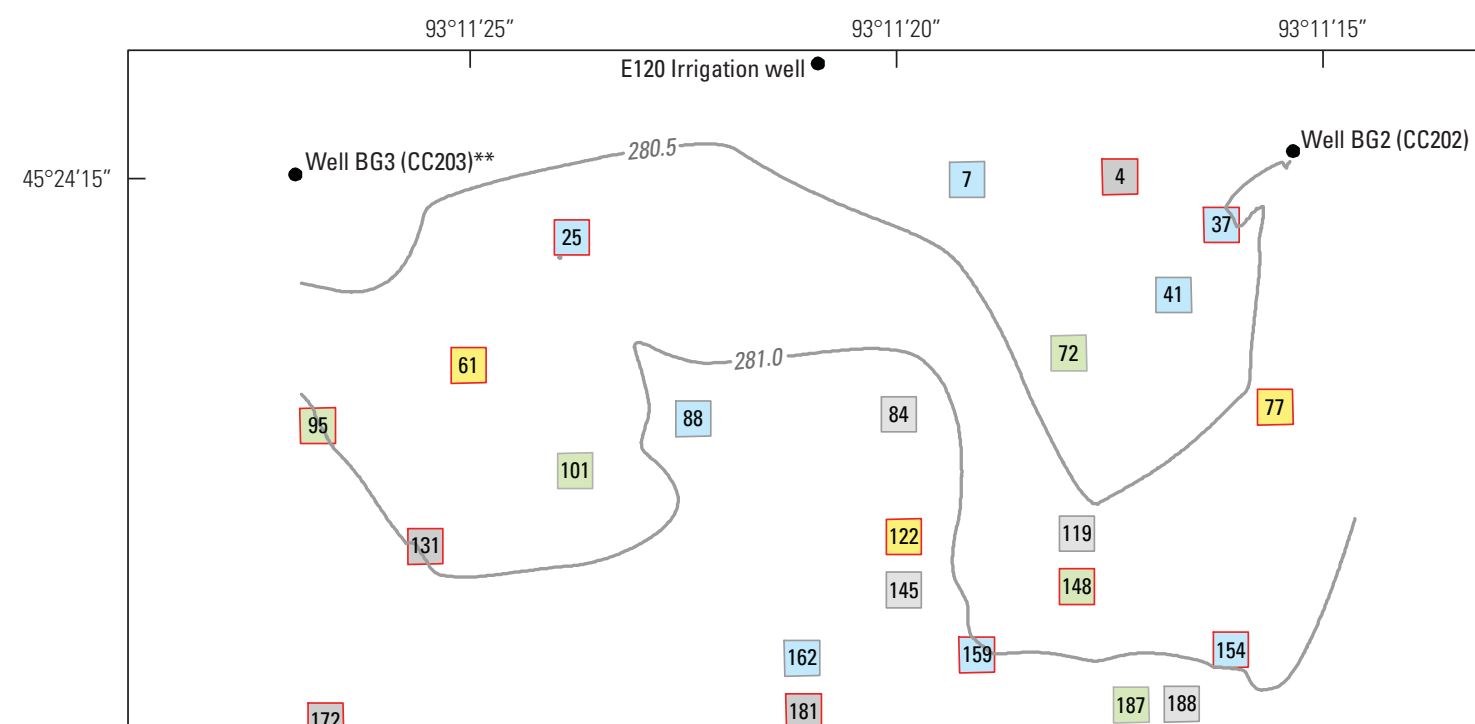

$45^{\circ} 24^{\prime} 10^{\prime \prime}$

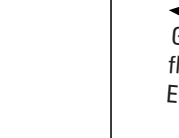

Generalized regional groundwater

flow direction (from Cedar Creek

Ecosystem Science Reserve, 2012c

$204 * *$

$217^{* *}$

$254^{* *}$

258

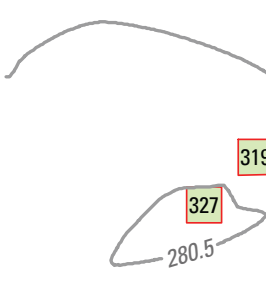

-Well BGO (CC200)

$45^{\circ} 24^{\prime} 05^{\prime \prime}$

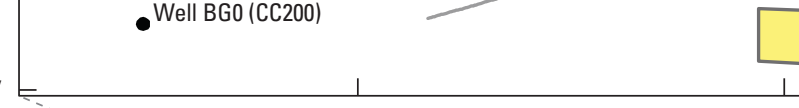

Base from Minnesota Department of Natural Resources digital data,

1:24,000, and U.S. Geological Survey digital data, 1:100,000

Universal Transverse Mercator projection, Zone 15

Horizontal coordinate information is referenced to the North

American Datum of 1983 (NAD 83)

\section{manum}

-280.5 - Land-surface contour, in meters above
National Geodetic Vertical Datum

of 1929. Contour interval 0.5 meter

\section{Plot with number}

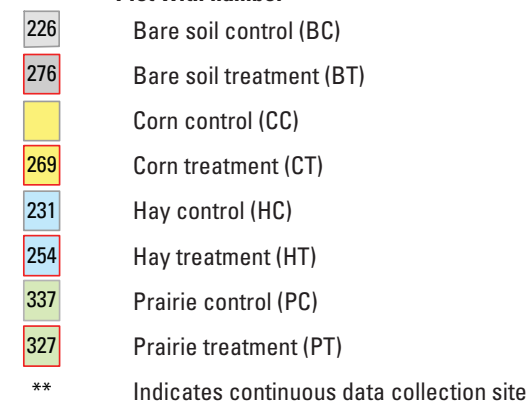

Figure 2. Layout of experimental field, land-surface topography, and regional groundwater-flow direction at Cedar Creek Ecosystem Science Reserve in east-central Minnesota.
226

231

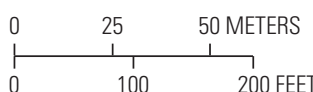

200 FEET

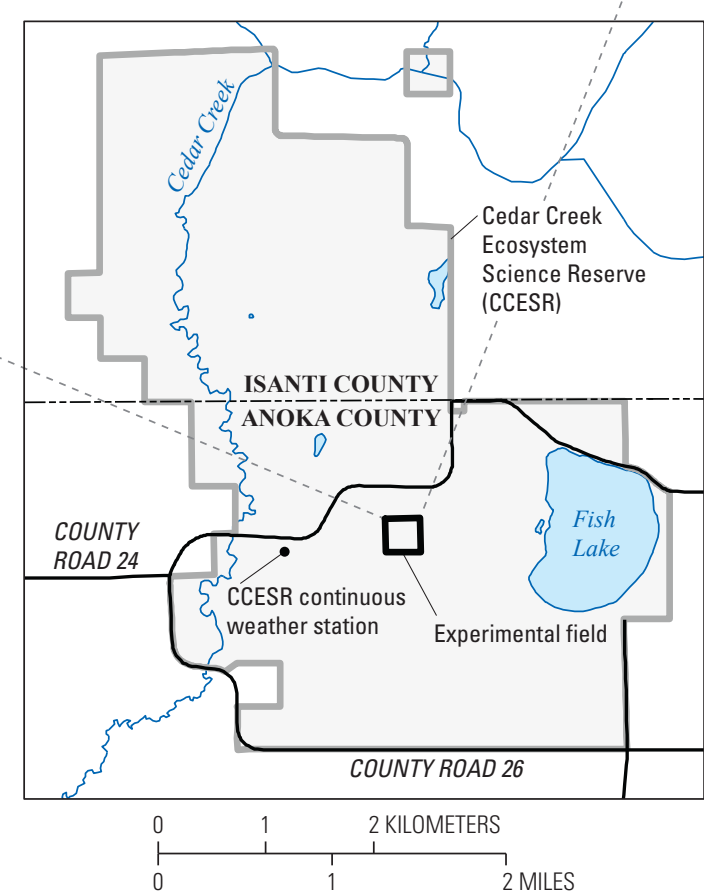




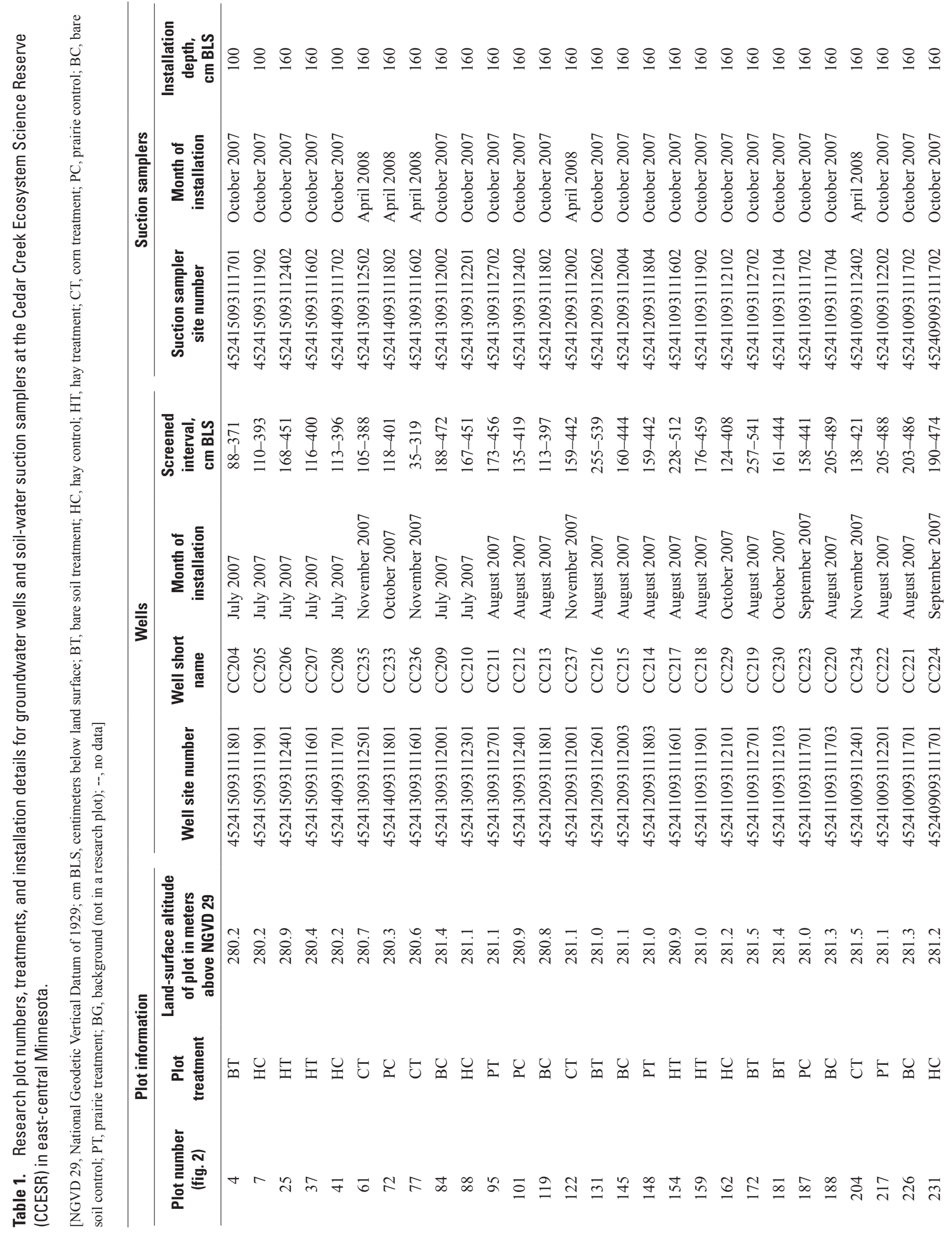




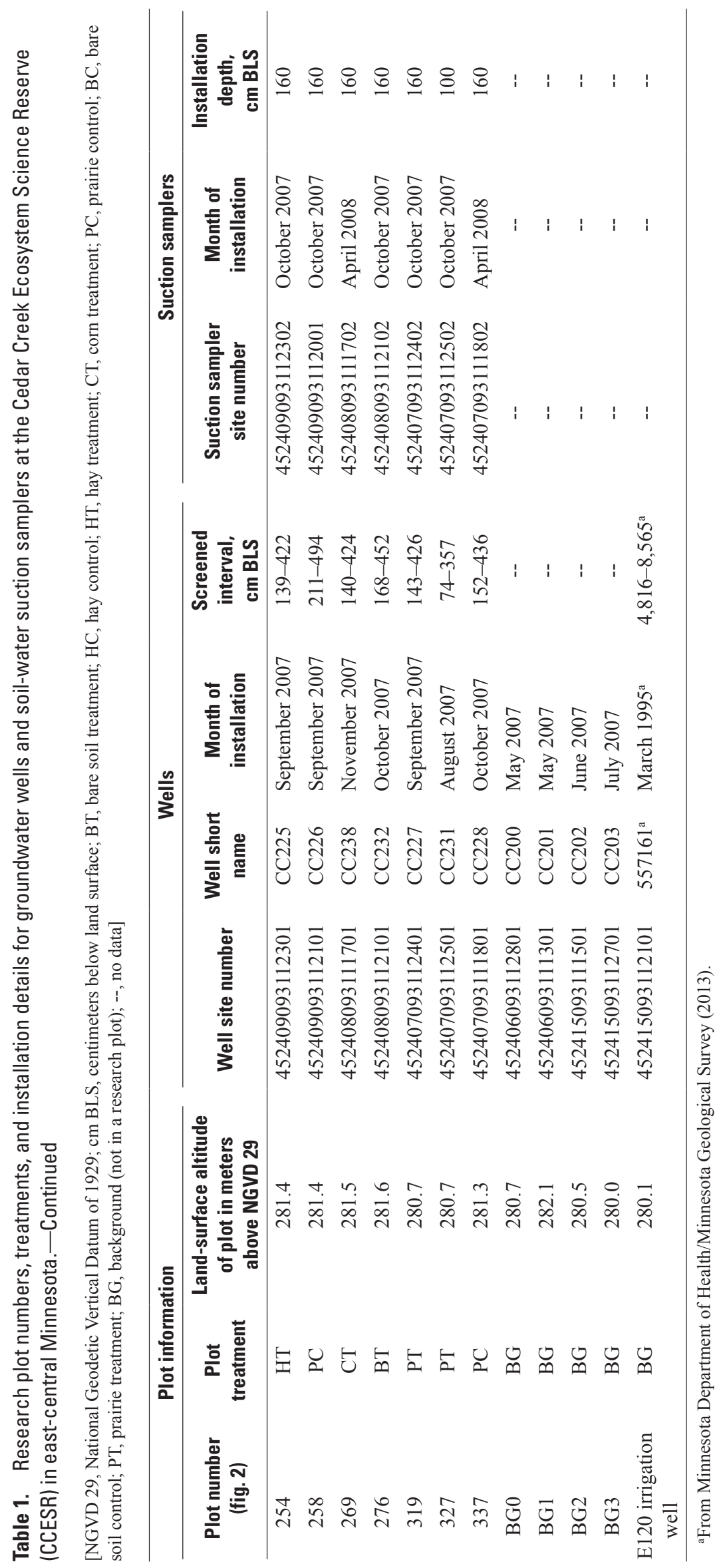


To establish the corn plots, the existing prairie vegetation was sprayed with glyphosate, mowed, and removed by raking in April 2008. Each plot was disked several times to break up the sod and prepare the seed bed. Corn was planted on May 1, 2008 , with row spacing of $91 \mathrm{~cm}$ at a seeding rate between 74,130 and 93,800 seeds per hectare (seeds/ha). The range in seeding rate resulted from variability in the decades-old planting equipment. Then in 2009, the plots were rototilled twice before planting. Corn was planted by hand on May 8, 2009, with row spacing of $76 \mathrm{~cm}$ at a rate of 76,850 seeds/ha. Starter fertilizer comprising 8 percent nitrogen, 10 percent diphosphorus pentoxide, 34 percent potassium oxide, and 5 percent potassium sulfate by mass was side-dress applied at a rate of 224 kilograms per hectare $(\mathrm{kg} / \mathrm{ha})$ at the time of planting in 2008 and 2009. Weeds were managed from May through October with biweekly to monthly glyphosate applications. In 2009 , some re-planting of corn was necessary in June because of damage by sandhill cranes. Urea $\left[\mathrm{CO}\left(\mathrm{NH}_{2}\right)_{2}\right]$ containing 46 percent nitrogen by weight was broadcast applied in late June of each season at a rate of $103 \mathrm{~kg} / \mathrm{ha}$. All corn fertilization and planting rates were recommended by an agronomist in Isanti, Minn., who was familiar with farming practices in the surrounding region (staff, Federated Coop, Isanti, Minn., oral commun., April 2008).

To establish the hay plots, the existing prairie vegetation was sprayed with glyphosate, mowed, and removed by raking in August through September of 2007. The seed bed was prepared by scraping the upper $5 \mathrm{~cm}$ of the soil profile with a blade pulled behind a lawn tractor. Hay plots were seeded in September 2007 with a CP-1 Conservation Reserve Program (CRP) mix consisting of the following species: smooth brome (Bromus inermis), alsike clover (Trifolium hybridum), and red clover (Trifolium pratense). Seeds for each species were applied at rates of 3.35 grams per square meter $\left(\mathrm{g} / \mathrm{m}^{2}\right)$, $0.76 \mathrm{~g} / \mathrm{m}^{2}$, and $0.07 \mathrm{~g} / \mathrm{m}^{2}$, respectively (Natural Resources Conservation Service, 2007). The plots were overseeded a month later at the same application rate. The seeds were spread by hand on the soil surface and then lightly raked into the soil. After the second seeding, a cover of $B$. inermis clippings was spread over the plots to minimize wind-driven seed losses. Ongoing management of hay plots required hand weeding to remove perennial prairie plants that were not killed in the original glyphosate application.

To establish the prairie plots, the existing prairie vegetation in these plots was left intact and overseeded according to the seed supplier's recommendations for establishing a native perennial CRP landscape (staff, Prairie Restorations Incorporated, oral commun., July 2007). Seeds were applied in September 2007 at the following rates: big bluestem (Andropogon gerardii), $0.42 \mathrm{~g} / \mathrm{m}^{2}$; yellow indian-grass (Sorghastrum nutans), $0.32 \mathrm{~g} / \mathrm{m}^{2}$; little bluestem (Schizachyrium scoparium), $0.16 \mathrm{~g} / \mathrm{m}^{2}$; switchgrass (Panicum virgatum), $0.11 \mathrm{~g} / \mathrm{m}^{2}$; blue grama (Bouteloua gracilis), $0.05 \mathrm{~g} / \mathrm{m}^{2}$; roundhead lespedeza (Lespedeza capitata), $0.42 \mathrm{~g} / \mathrm{m}^{2}$; mintleaf beebalm (Monarda fistulosa), $0.01 \mathrm{~g} / \mathrm{m}^{2}$; leadplant (Amorpha canescens), $0.02 \mathrm{~g} / \mathrm{m}^{2}$; purple prairie clover (Dalea purpurea), $0.03 \mathrm{~g} / \mathrm{m}^{2}$; silky prairie clover (Dalea villosa), $0.21 \mathrm{~g} / \mathrm{m}^{2}$; stiff-leaved goldenrod (Solidago rigida), $0.11 \mathrm{~g} / \mathrm{m}^{2}$; stiff tickseed (Coreopsis palmata), $0.02 \mathrm{~g} / \mathrm{m}^{2}$; and gray goldenrod (Solidago nemoralis), $0.01 \mathrm{~g} / \mathrm{m}^{2}$.

\section{Maintenance}

All 35 research plots were completely harvested (mowed at $7.6 \mathrm{~cm}$ above land surface) in November 2008 and November 2009 to quantify the annual biomass production. Additionally, most of the remaining senesced plant material on the soil surface was burned in April of each year, according to the annual CCESR management practice of the experimental field (Cedar Creek Ecosystem Science Reserve, 2012a). The prescribed burns were of low intensity because of the small amounts of litter remaining on the plots in the spring.

\section{Field Instrumentation}

Plots were instrumented for observing one or more of the following: volumetric soil-water content, soil temperature, groundwater levels, and soil-water and groundwater quality (fig. 3). Meteorological data including relative humidity, air temperature, solar radiation, wind speed, wind direction, and precipitation were measured at a weather station managed by CCESR approximately 1 kilometer $(\mathrm{km})$ west of the experimental field (fig. 2; Cedar Creek Ecosystem Science Reserve, 2010). Precipitation in the experimental field also was measured at plot 254 (fig. 2) with a Texas Electronics 525M heated tipping bucket rain gage. Additional details on field instrumentation installation procedures are provided in Trost (2010).

Soil hydrology was characterized with continuous and discrete monitoring approaches. The design of the continuous monitoring system is similar to other published works that link unsaturated soil processes to shallow groundwater (Delin and others, 2000; Delin and Herkelrath, 2005). Continuous measurements of soil temperature and volumetric soil-water content were made in four plots, one of each land-cover type: plot 204 (corn), plot 217 (prairie), plot 254 (hay), and plot 276 (bare soil) (figs. 2 and 3). The continuous soil-temperature and volumetric soil-water content datasets for March 2008 through December 2009 are available in appendix 1 (tables 1-1, 1-2, and 1-3). Soil-temperature and volumetric soil-water content measurements were made with Campbell Scientific ${ }^{\circledR} 107-\mathrm{L}$ and CS616 time domain reflectometry (TDR) sensors, respectively, at 25, 50,100,150, and $200 \mathrm{~cm}$ below land surface. Discrete measurements of volumetric soil-water content profiles were made weekly to biweekly in all of the plots from May through October of 2008 and 2009 using a TRIME ${ }^{\circledR}$-FM tube-access TDR probe system (Mesa Systems Co., Stonington, Connecticut). Details of installation of soil-water content monitoring equipment and data processing are described in Trost (2010).

Suction samplers (suction lysimeters) constructed by the USGS were used for collecting soil-water samples (Richard Healy, U.S. Geological Survey, oral commun., July 2007). 


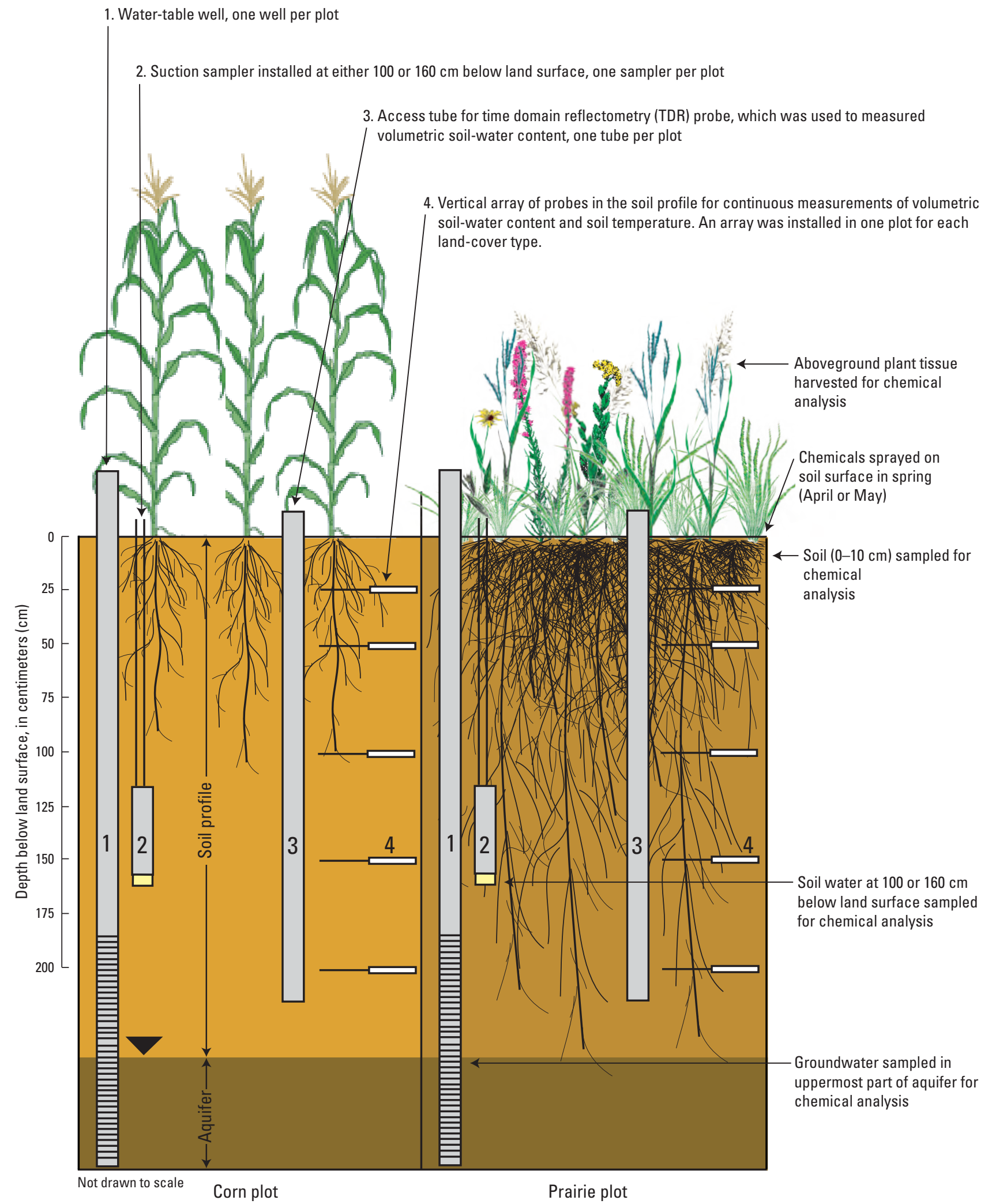

Figure 3. Cross-section diagram of sampling locations within the soil profile and field instrumentation used for measuring soilwater content, soil temperature, groundwater levels, and soil-water and groundwater quality. 
The samplers comprised three components: a sample collection body, a polytetrafluoroethylene (PTFE) sample line, and a PTFE vacuum line. The sample body consisted of a polyvinyl chloride (PVC) tube with a 3.8-cm diameter, a 100-kilopascal $(\mathrm{kPa})$ high-flow porous ceramic cup, and a PVC cap affixed with epoxy. All suction sampler parts were washed thoroughly and rinsed with deionized water before construction. After construction, the suction samplers were flushed with deionized water until the specific conductance of the water leaving the sampler was equal to that of the water flowing into the sampler. Before installation at the field site, all of the suction samplers were again vacuum-tested and rinsed with deionized water.

One suction sampler was installed in each of the 35 research plots to collect soil water below the rooting zone that had not yet reached the water table. Previous research of the Anoka Sand Plain estimated, on the basis of root distribution data, that the maximum depth of water withdrawal by corn crops was $75 \mathrm{~cm}$ below land surface (Delin and others, 2000). In a different experiment at the CCESR research site, soil-water withdrawals by perennial prairies were observed down to $100 \mathrm{~cm}$ below land surface through periodic measurements of volumetric soil-water content (Cedar Creek Ecosystem Science Reserve, 2012b), indicating that suction samplers should be installed deeper than $100 \mathrm{~cm}$; the samplers also needed to be at least $50 \mathrm{~cm}$ above the water table to minimize the possibility of sampling the capillary fringe of the water table. All but four of the suction samplers were installed to a depth of $160 \mathrm{~cm}$ below land surface (table 1). Four of the research plots were located in topographically lower areas where the distance between land surface and the water table was insufficient for a $160-\mathrm{cm}$ installation depth. The suction samplers in these four plots were installed at a depth of $100 \mathrm{~cm}$ below land surface (table 1). Suction samplers were installed in October 2007. Several were damaged during the winter and subsequently replaced in April 2008. The suction samplers were installed in the center of each research plot. A 5 -cm diameter hole was bored to the appropriate depth with a hand auger. The suction sampler body was placed in the hole, and a silica powder/deionized water slurry was poured around the ceramic cup to provide good contact with the surrounding soil. Once the ceramic cup was embedded securely within the silica slurry, the borehole was backfilled. Immediately above the top of the sampler body and extending upward by $30 \mathrm{~cm}$, bentonite clay was packed in the borehole. Above this point, and extending to land surface, native material was packed in the borehole.

Water-table wells were installed in each plot and in four background locations (BG0-BG3 wells in table 1) for measuring water levels and collecting groundwater-quality samples from the uppermost part of the surficial aquifer (figs. 2 and 3). The wells were installed on the downgradient (west) side of each plot to maximize the probability of sampling water that had traveled through the soils of the overlying plot. Regional groundwater-flow direction was determined from historical groundwater levels measured at the research site (Cedar Creek
Ecosystem Science Reserve, 2012c). Each well was constructed of flush-couple 5-cm diameter PVC casing, a 3.05-m PVC screen with slot size 10 [0.25-millimeter (mm) gap], and a 5-cm wash-down valve (part number WDV2, Bigfoot Manufacturing Company, Cadillac, Mississippi) that sealed the bottom of the well casing.

Wells were installed from May through November 2007 using a $7.5-\mathrm{cm}$ diameter rotary auger. Boreholes were drilled from land surface to between 150 and $200 \mathrm{~cm}$ below the water table. After the desired depth was reached, the augers were pulled from the borehole resulting in collapse of the hole below the water table. The entire well assembly (casing, screen, and wash-down valve) was assembled aboveground and then inserted into the borehole to the depth of collapsed aquifer materials. A stream of water from the irrigation well in the experimental field was forced through the wash-down valve at the bottom of the well screen so that the well assembly could be pushed by hand through the collapsed aquifer material. The well screen was centered approximately at the water-table surface (table 1). Generally, each well installation required less than 8 liters (L) of water. After the well screen was in place, native material was packed in the annular space from the water table to approximately $120 \mathrm{~cm}$ below land surface. The remainder of the annular space was sealed with bentonite. Steel protector pipes, $15 \mathrm{~cm}$ in diameter and $110 \mathrm{~cm}$ long, were placed over the stickup of each well. Each well was developed with a submersible pump for at least 20 minutes.

Groundwater levels were measured continuously at two of these water-table wells in the experimental field: the plot 254 well and the BG3 well (table 1; fig. 2). A Druck PDCR 800 series transducer was used at the plot 254 well site and a Design Analysis Model H310 transducer was used at the BG3 well site. Water levels measured by using pressure transducers were checked by discrete steel tape or electronic tape measurements approximately monthly to bimonthly throughout the study. A detailed description of the processing of the groundwater-level record is included in Trost (2010). The entire groundwater-level record for March 2008 through December 2009 for the plot 254 well is available in appendix 2.

\section{Chemical Application}

A solution containing sulfamethazine (SMZ), sulfamethoxazole (SMX), 17-beta-estradiol (17BE), and two conservative tracers, bromide and rhodamine WT (RWT), was applied to the 20 treatment plots in May 2008 (table 2). A solution containing only SMZ, SMX, and 17BE was applied to the same 20 treatment plots in April 2009. The general preparation procedure for each of these chemicals was to make a concentrate, combine and dilute the concentrates with groundwater from an irrigation well in the experimental field (fig. 2) in a 133-L polyethylene tank, and then spray the diluted solution on the soil surface of the plot. The dates of application are listed in table 2, and details of solution preparation are described in the following text. 
In 2008, SMZ and SMX were applied at a rate of 5.6 milligrams per square meter $\left(\mathrm{mg} / \mathrm{m}^{2}\right)$ and 17BE was applied at a rate of $0.2 \mathrm{mg} / \mathrm{m}^{2}$. In 2009, SMZ and SMX were applied at a rate of $11.2 \mathrm{mg} / \mathrm{m}^{2}$ and $17 \mathrm{BE}$ was applied at a rate of $0.4 \mathrm{mg} / \mathrm{m}^{2}$. The 2008 application rates correspond to antibiotic and $17 \mathrm{BE}$ concentrations in manure of 1.0 milligram per liter $(\mathrm{mg} / \mathrm{L})$ and $0.026 \mathrm{mg} / \mathrm{L}$, respectively, at a manure application rate of 56,100 liters per hectare $(\mathrm{L} / \mathrm{ha})$. This is a moderate application rate for liquid swine manure and a low application rate for liquid dairy manure as recommended by the Minnesota Pollution Control Agency (Minnesota Pollution Control Agency, 2012) for soil nitrogen management. A concentrated solution containing SMZ, SMX, and 17BE was prepared in the laboratory 1 to 3 weeks before application. Granular SMZ, SMX, and 17BE (Sigma Aldrich ${ }^{\mathrm{TM}}$ part numbers S6256, S7507, and E8875) were each weighed to the nearest 0.0005 gram $(\mathrm{g})$ and added slowly to 800 milliliters $(\mathrm{mL})$ of methanol. An additional $200 \mathrm{~mL}$ of methanol and $1 \mathrm{~L}$ of deionized water were then added to the solution, which was stirred for at least 15 minutes until all solids had dissolved. This 2-L solution was transferred to a 4-L glass amber bottle. Another identical 2-L solution was made and poured into the 4-L glass amber bottle. The solution was stored in a refrigerator at approximately $4{ }^{\circ} \mathrm{C}$ until the time of application. No precipitate was observed in the solution after refrigerated storage.

The two tracers, bromide and RWT, were applied in 2008 with SMZ, SMX, and 17BE to track the transport of conservative solutes through the soil profile and groundwater. These two tracers had been used successfully in previous soil profile tracing studies (Kung, 1990; Delin and others, 2000). A concentrated potassium bromide $(\mathrm{KBr})$ solution was prepared in the field by dissolving $907.4 \mathrm{~g} \mathrm{KBr}$, (minimum 99-percent purity) in $11 \mathrm{~L}$ of water. The solution was then applied at a rate of $10 \mathrm{~g}$ of bromide per square meter, a rate similar to that used in other studies (Kung, 1990). The RWT tracer (20-percent active ingredient) was applied at a rate of $6 \mathrm{~g}$ active ingredient per square meter, a rate similar to a study done on sandy soils near Bemidji, Minn., to examine recharge through the soil profile (Geoffrey Delin, U.S. Geological Survey, oral commun., August 2007).

The concentrated bromide solution and the concentrated SMZ, SMX, and 17BE solution were added to the 133-L application tank as it was being filled with groundwater supplied by the irrigation well (E120 irrigation well in fig. 2). The concentrated 20 -percent RWT solution $(1,815 \mathrm{~mL})$ was added to the tank after it was nearly full to minimize foam formation. After adding the RWT solution, the entire tank was sealed, agitated for 5 minutes, and then hitched to an all-terrain vehicle and towed to the plot. In 2008, the concentrated solutions were prepared such that each plot received two 133-L volumes from the application tank to achieve the chemical mass per area application rate. In 2009, the tracers were not added, and the concentrated SMZ, SMX, and 17BE solution was prepared such that each plot received one 133-L volume from the application tank to achieve the chemical mass per area application rate.
The thoroughly mixed diluted solution was applied to a plot through two independent sprayer systems, each consisting of a submersible pump connected to a spray nozzle with $15.5 \mathrm{~m}$ of PVC tubing. The two submersible pumps were placed in the 133-L tank. Technicians sprayed the solution on the plot surface through the spray nozzle ends. Each plot surface was prepared for application by removing as much senesced plant material as possible through burning and raking. Several measures were implemented to distribute the solution as evenly as possible within each plot. Each plot was divided into four equal-area quadrants. The spray nozzles were adjusted to minimize surface ponding and fine mist production. The spraying of each application tank was done in three passes. The first two passes were done slowly for complete coverage. The technicians switched quadrants after the first pass to equalize differences between sprayer systems and technicians. The third pass was a rapid application to evenly distribute any remaining solution and $16 \mathrm{~L}$ of rinse water added to the tank.

\section{Collection and Storage of Field Samples}

Sampling event types and dates are summarized in table 2. Plant-tissue, soil, soil-water, and groundwater samples were analyzed for one or more of the following: SMZ, SMX, $17 \mathrm{BE}$, and bromide (summarized in table 3). Collection of water samples for bromide analysis began in April 2008 (before any chemical application) and continued through October 2009. These tracer samples were collected to identify any differences in conservative solute movement through the soil profile underlying the different land-cover types. Previous research on the Anoka Sand Plain indicated a tracer traveltime of 95 to 110 days through 260 to $440 \mathrm{~cm}$ of sandy soil (Delin and others, 2000). Collection of water samples for SMZ, SMX, and 17BE began in October 2008, when several soilwater samples from treatment plots contained bromide (Trost, 2010). Plant-tissue and soil sampling events were concentrated in year two of the study (April 2009 through August 2009) to understand the fate of the chemicals in these matrices after two seasons of application.

\section{Aboveground Plant Tissues and Root Biomass}

Vegetation samples (plant tissues and root biomass) were collected for the extraction and analysis of SMZ, SMX, and 17BE in June 2009 and August 2009 (table 2). Vegetation taller than $1 \mathrm{~cm}$ was clipped from a 0.6 -square meter $\left(\mathrm{m}^{2}\right.$; $0.1 \mathrm{~m}$ by $6 \mathrm{~m}$ ) area within each plot. All clipped plant material was gathered into a plastic bag and stored on ice in the field. In the laboratory, the fresh weight of the entire sample was measured. A 100-g grab sample was collected from the vegetation for extraction and determination of SMZ, SMX, and 17BE concentrations. The 100-g grab sample was weighed, wrapped in aluminum foil, placed in a plastic bag, sealed, and stored at $-17^{\circ} \mathrm{C}$ until further processing could be completed. 
Table 2. Dates of chemical applications and soil-water, groundwater, soil, and plant-tissue sampling events for measurements of sulfamethoxazole, sulfamethazine, 17-beta-estradiol, and bromide.

[Unless otherwise indicated, a sampling event included treatment and control plots. SMZ, sulfamethazine; SMX, sulfamethoxazole; 17BE, 17-beta-estradiol; --, no data; cm, centimeter]

\begin{tabular}{|c|c|c|}
\hline Event & Chemical analyses completed & Date \\
\hline Groundwater sampling & Bromide & April 16-28, 2008 \\
\hline $\begin{array}{l}\text { Application of SMZ, SMX, and } 17 \mathrm{BE} \text { and bromide tracer } \\
\text { to } 20 \text { treatment plots }\end{array}$ & -- & May 6-22, 2008 \\
\hline Soil-water sampling & Bromide & May 6-7, 2008 \\
\hline Soil-water sampling & Bromide & June $11-13,2008$ \\
\hline Soil-water sampling & Bromide & June $17-19,2008$ \\
\hline Groundwater sampling of background wells & Bromide & June $25-26,2008$ \\
\hline Soil-water sampling & Bromide & July 1,2008 \\
\hline Soil-water sampling & Bromide & July $7-8,2008$ \\
\hline Groundwater sampling & Bromide & July $14-$ August 12,2008 \\
\hline Soil-water sampling & Bromide & July $16-17,2008$ \\
\hline Soil-water sampling & Bromide & July 25, 2008 \\
\hline Soil-water sampling & Bromide & July $30-$ August 1, 2008 \\
\hline Soil-water sampling & Bromide & August 14, 2008 \\
\hline Soil-water sampling & Bromide & September 3, 2008 \\
\hline Soil-water sampling & Bromide & September 17, 2008 \\
\hline Groundwater sampling & Bromide & September 18, 2008 \\
\hline Soil-water sampling & Bromide & September 30, 2008 \\
\hline Groundwater sampling & Bromide & October $1-3,2008$ \\
\hline Groundwater sampling & Bromide & October 8, 2008 \\
\hline Soil-water sampling & Bromide & October 10, 2008 \\
\hline Groundwater sampling & Bromide & October 30-November 24, 2008 \\
\hline Soil-water sampling & Bromide & October 31-November 3, 2008 \\
\hline Groundwater sampling & Bromide & December 8-9, 2008 \\
\hline Soil-water sampling & SMZ, SMX, 17BE, Bromide & October 31,2008 \\
\hline $\begin{array}{l}\text { Groundwater sampling in one treatment plot of each bare soil, } \\
\text { corn, and prairie }\end{array}$ & SMZ, SMX, 17BE, Bromide & March 23, 24, and 26, 2009 \\
\hline Soil-water sampling & SMZ, SMX, 17BE, Bromide & April 9, 2009 \\
\hline Application of SMZ, SMX, and 17BE to 20 treatment plots & -- & April 27-29, 2009 \\
\hline Soil sampling $(0-10 \mathrm{~cm})$ & SMZ, SMX, 17BE & April 27-30, 2009 \\
\hline Soil-water sampling & SMZ, SMX, 17BE, Bromide & June 10, 2009 \\
\hline Groundwater sampling & SMZ, SMX, 17BE, Bromide & June 9-11, 2009 \\
\hline Soil sampling $(0-10 \mathrm{~cm})$ & SMZ, SMX, 17BE & June 17-18, 2009 \\
\hline Aboveground plant-tissue sampling & SMZ, SMX,17BE, Biomass & June 23-24, 2009 \\
\hline Soil-water sampling & SMZ, SMX, 17BE, Bromide & July 2, 2009 \\
\hline Belowground (root) sampling $(0-30 \mathrm{~cm})$ & Biomass & July 20-27, 2009 \\
\hline Aboveground plant-tissue sampling & SMZ, SMX,17BE, Biomass & August 26-27, 2009 \\
\hline Soil-water sampling & SMZ, SMX, 17BE, Bromide & September 3-4, 2009 \\
\hline Soil-water sampling & SMZ, SMX, 17BE, Bromide & October 7, 2009 \\
\hline Groundwater sampling & SMZ, SMX, 17BE, Bromide & October 10-13, 2009 \\
\hline
\end{tabular}




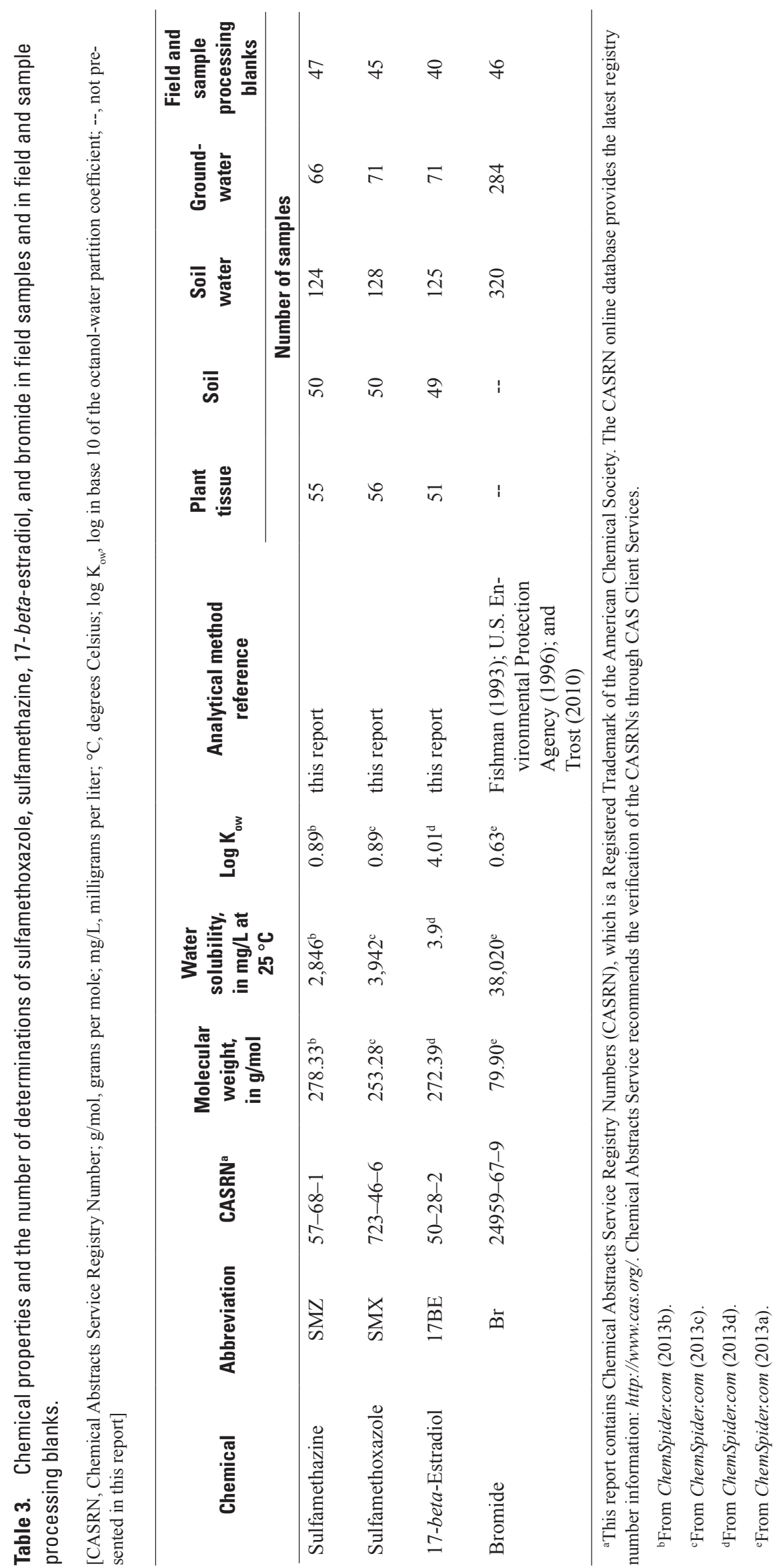


Plant-tissue samples were then dried at $40{ }^{\circ} \mathrm{C}$ for 24 hours, ground to a coarse powder, and transferred into $40-\mathrm{mL}$ glass amber volatile organic analysis (VOA) vials. Between the grinding of each sample, the grinding equipment was vacuumed off, blown with compressed air, washed with methanol, and dried with compressed air. The vials containing the ground plant-tissue samples were stored at $-17^{\circ} \mathrm{C}$ until sample extraction and analysis.

Root biomass in the upper $30 \mathrm{~cm}$ of the soil profile of each plot was sampled in July 2009 (table 2). Each plot's root sample was a composite of six individual cores collected with a 5-cm diameter corer. The six individual cores in bare soil, hay, and prairie plots were taken at equally spaced intervals along a 6-m transect. The six individual cores in corn plots were taken along a 6-m transect that was perpendicular to the direction of the planted rows. Three of the cores in each corn plot were taken in rows and three cores were taken midway between the rows. The field sample comprised soil and roots. Roots were separated from the soil by gently spraying the sample with water on a screen with $1-\mathrm{mm}$ mesh openings. The screen retained the roots as the soil was washed away. After the roots were cleaned of soil, they were dried at $40{ }^{\circ} \mathrm{C}$ for at least 1 week and then weighed.

\section{Soil Samples}

Soil samples were collected for the extraction and analysis of SMZ, SMX, and 17BE in 10-cm vertical increments from land surface to a maximum depth of $30 \mathrm{~cm}$ from a subset of plots, although only data from the upper $10 \mathrm{~cm}$ of soil are presented in this report. Each soil sample was a composite of five individual cores collected in a plot with disposable $5-\mathrm{cm}$ diameter PVC corers. Upon removal from the plot, the open ends of each PVC corer immediately were covered with aluminum foil and plastic. The samples were then placed on ice and transferred to a freezer where they remained frozen until further processing could be completed.

Immediately after taking the cores out of the freezer, each PVC corer body was cut longitudinally on two sides to gain access to the full vertical extent of the soil sample. A stainless steel knife was used to cut cores longer than $10 \mathrm{~cm}$ into $10-\mathrm{cm}$ vertical increments. The soil that was in direct contact with the PVC corer body was scraped off with a stainless steel spatula. This scraped soil was weighed moist, dried at $105^{\circ} \mathrm{C}$ for at least 48 hours, and then reweighed to determine the gravimetric moisture content of the composite soil sample. A separate part of the scraped soil was used to measure soil $\mathrm{pH}$. The soil $\mathrm{pH}$ was determined in a 1:1 soil:deionized water suspension ( $5 \mathrm{~g}$ soil to $5 \mathrm{~mL}$ deionized water) ratio with a glass and reference electrode attached to an Orion 250A pH meter (Thermo Fisher Scientific, Waltham, Massachusetts). A clean spatula was then used to extract soil from the inner part of the soil core to be used for extraction and analysis of SMZ, SMX, and 17BE. The inner soil from all five sub-cores for each $10-\mathrm{cm}$ increment was combined into a clean stainless steel bowl. This soil was homogenized and seived through a $2-\mathrm{mm}$ stainless steel sieve to remove roots and large stones. The seived soil was dried at $40{ }^{\circ} \mathrm{C}$ for 24 hours and then stored in clean 120 -mL glass amber jars at $-17^{\circ} \mathrm{C}$ until chemical extraction and analysis.

\section{Water Samples}

Soil-water samples were collected periodically from May 2008 through October 2009 and groundwater samples were collected periodically from April 2008 through October 2009 (table 2). All water samples were pumped through PTFE and $\mathrm{C}-\mathrm{flex}^{\mathrm{TM}}$ or silicon tubing during collection. Equipment that contacted sample water was cleaned three times with a 2-percent phosphate-free detergent solution (Liquinox ${ }^{\mathrm{TM}}$ ), rinsed three times with tap water, rinsed three times with deionized water, rinsed three times with methanol, and stored in a clean plastic bag between uses. Soil-water and groundwater samples were analyzed for one or more of the following: SMZ, SMX, 17BE, and bromide. Additionally, onsite waterquality characteristics of specific conductance, $\mathrm{pH}$, dissolved oxygen, and temperature were measured in groundwater at the time of sample collection.

Soil water was sampled by applying a vacuum of between 40 and $45 \mathrm{~cm}$ of mercury to each PVC suction sampler for a period of approximately 24 hours. The accumulated soil water in the suction sampler body was then extracted with either a peristaltic or hand pump. Groundwater wells were sampled at low-flow rates [0.4 to 1.5 liters per minute $(\mathrm{L} / \mathrm{min})]$ with a peristaltic pump. A packer was placed in the well $5 \mathrm{~cm}$ to $10 \mathrm{~cm}$ below the water-table surface to isolate the uppermost part of the aquifer. This was done to maximize the probability of sampling water that had traveled through the soil profile of the overlying plot. The packer depth depended on the productivity of the well. It was moved deeper than $5 \mathrm{~cm}$ below the water-table surface (to a maximum of $10 \mathrm{~cm}$ ) if the well productivity was too low for the pumping rate. Onsite water-quality characteristics of specific conductance, $\mathrm{pH}$, dissolved oxygen, and temperature were measured during groundwater sampling with a YSI 6820 water-quality multiprobe meter before the collection of water samples for laboratory analyses. The specific conductance, $\mathrm{pH}$, and dissolved oxygen probes on the multiprobe meter were calibrated on each of the sampling dates before sampling according to standard USGS procedures (U.S. Geological Survey, variously dated). The wells were purged with the packer in place until the characteristics stabilized or for 8 minutes, whichever came first. Onsite water-quality characteristics were not measured in soil-water samples because sample volumes were insufficient for accurate determinations with the YSI 6820.

Soil-water and groundwater samples collected for determination of SMZ, SMX, and 17BE were processed as follows (tables 2 and 3). Samples were filtered through an in-line stainless steel barrel filter apparatus containing a baked $47-\mathrm{mm}$ diameter 0.7-micron $(\mu \mathrm{m})$ glass-fiber filter. Each filtered sample comprised duplicate or triplicate baked amber glass vials 
filled approximately one-third full. The filtered samples were stored at $-17^{\circ} \mathrm{C}$ until chemical analyses could be completed.

Soil-water and groundwater samples collected for bromide analysis were processed in one of two ways, depending on the analytical method that was to be used on that sample. Samples collected for analysis by ion chromatography at the USGS National Water Quality Laboratory in Denver, Colorado, using methods summarized by Fishman (1993) were filtered in the field through a Whatman $0.45-\mu \mathrm{m}$ in-line capsule filter as described in the USGS National Field Manual (U.S. Geological Survey, variously dated). Samples collected for analysis with an Orion 96-35 ionplus ${ }^{\circledR}$ Series Bromide Electrode were not filtered (U.S. Environmental Protection Agency, 1996).

\section{Laboratory Analytical Procedures}

Concentrations of SMZ, SMX, and 17BE in aboveground plant tissue, soil, soil water, and groundwater were determined with ELISA kits purchased from Abraxis, LLC. The analytical procedure is described briefly in this section, and in more detail in appendix 3. ELISA kits have been used to determine concentrations of antibiotics in plants, soils, water, and manure in a number of studies (Aga and others, 2003; Kumar and others, 2004; Dolliver, Gupta, and Noll, 2008; Dolliver, Kumar, and others, 2008; Dolliver and Gupta, 2008a, 2008b). The basic principle of operation of ELISA kits is as follows. When combined in an analysis vial, the chemical of interest in an environmental sample (not color labeled) competes with a color-labeled variant of the same chemical (provided with each ELISA kit) for antibody binding sites. The more antibody binding sites that are filled with the color-labeled variant in the analysis vial, the more intense the color development. Color development is measured as the light absorbance at the 450-nanometer (nm) wavelength; more intense color development leads to greater absorbance. In an environmental sample with no chemical of interest, all of the antibody binding sites in the analysis vial get filled with the color-labeled variant, leading to maximum color development. Any increase in the concentration of the chemical of interest in the environmental sample decreases the amount of the color-labeled variant bound to the antibodies in the analysis vial, leading to less color development. Chemical concentrations in environmental samples are therefore inversely proportional to the color development (absorbance) measured during sample analysis. The absorbance of samples analyzed with SMZ or 17BE magnetic particle kits was measured with an Ohmicron RPA-1 Analyser (Newtown, Pa.). The absorbance of samples analyzed with SMX microtiter kits was measured on a Dynatech Laboratories MRX microplate reader. According to the kit manufacturer (Abraxis, 2010a, 2010b, 2010c), there was little cross-reactivity of the kits for SMZ, SMX, and 17BE. "Little cross-reactivity" means, for example, that an environmental sample with a high concentration of SMZ would not have caused false high positive readings for 17BE or SMX on those respective kits. The kits were specific to their respective chemicals.

A citric acid buffer solution, 50-percent methanol and 50-percent 0.3 -molar (M) citric acid at $\mathrm{pH} 6$ by volume (described in more detail in appendix 3), was added to the dried, homogenized plant-tissue and soil samples to extract SMZ, SMX, and 17BE from the solid matrices. The extract samples (vials containing solid samples and citric acid buffer) were then centrifuged and filtered to remove the solids from the extract sample. The filtered supernatant was then evaporated under ultra-high purity nitrogen gas to remove the methanol. This acidic extraction and evaporation method has been used successfully for the extraction of antibiotic chemicals from soil matrices (Michael Meyer, U.S. Geological Survey, oral commun., December 2008). Every soil and plant-tissue sample was extracted and analyzed as an unspiked/spiked pair so that the recovery of each chemical in every sample could be determined. In contrast to the plant-tissue and soil samples, soil-water and groundwater samples were analyzed raw, meaning they were not extracted or concentrated before ELISA analysis.

Serial dilutions were done on a subset of the plant and soil-extract solutions to identify a dilution level for each chemical and matrix combination that minimized matrix interference with kit performance and permitted spike detections within each kit's range (described in more detail in appendix 3). Diluent provided with each ELISA kit was used to dilute the samples.

Water samples sent to the USGS National Water Quality Laboratory in Denver, Colorado, were analyzed by ion chromatography for dissolved ions, including bromide and chloride, as described by Fishman (1993). The calibration and measurement procedures for water samples analyzed by the Orion 96-35 ionplus ${ }^{\circledR}$ Series Bromide Electrode ${ }^{\mathrm{TM}}$ attached to an Orion $250 \mathrm{~A}^{\mathrm{TM}}$ portable $\mathrm{pH}$ meter are summarized in Trost (2010), the probe manufacturer's manual (Thermo Fisher Scientific Incorporated, 2008), and by the U.S. Environmental Protection Agency (1996). This bromide ion selective electrode was well-suited to the field conditions in this experiment because background concentrations of dissolved ions, other than bromide, in soil water and groundwater were low. The specific conductance of groundwater at the research site was between 25 microsiemens per centimeter at $25^{\circ} \mathrm{C}(\mu \mathrm{S} / \mathrm{cm})$ and $135 \mu \mathrm{S} / \mathrm{cm}$. Dissolved ions in much greater concentrations than bromide are known to adversely affect bromide measurements with ion-specific electrodes; for example, chloride concentrations of more than 180 times the bromide concentration in milligrams per liter $(\mathrm{mg} / \mathrm{L})$ will cause the Orion 96-35 ionplus ${ }^{\circledR}$ Series Bromide Electrode to malfunction (U.S. Environmental Protection Agency, 1996; Thermo Fisher Scientific Incorporated, 2008). Chloride concentrations ranged between 0.07 and $4.16 \mathrm{mg} / \mathrm{L}$, and bromide concentrations ranged between less than 0.02 and $179 \mathrm{mg} / \mathrm{L}$ in water samples collected at the study site. 


\section{Calculations and Statistics}

The ELISA kit-specific calibration curves were calculated with a least-squares regression procedure that related the observed relative percent absorbance to the expected concentrations of manufacturer-provided calibration standards. This procedure is described in detail in appendix 3. Every standard, control, and environmental sample was analyzed in duplicate. The relative percent absorbance of each sample was calculated as follows:

$$
A_{r}=\frac{\overline{A_{s}}}{\overline{A_{0}}} \times 100
$$

where

$$
\begin{aligned}
& A_{r} \quad \begin{array}{l}
\text { is the relative percent absorbance at } \\
450 \text { nanometers, }
\end{array} \\
& \overline{A_{s}} \quad \text { is the mean of duplicate measurements of } \\
& \text { absorbance at } 450 \text { nanometers for each } \\
& \text { sample, and } \\
& \overline{A_{0}} \quad \text { is the mean of duplicate measurements of } \\
& \text { absorbance at } 450 \text { nanometers for the kit's } \\
& \text { zero standard. }
\end{aligned}
$$

The relative percent absorbance was then used in the kitspecific calibration equation to calculate the sample concentration. No more than 80 samples were analyzed per any one calibration series.

\section{Precision and Accuracy of ELISA-Determined Concentrations}

The variability of repeated measurements of a chemical concentration in a sample, including field replicates and laboratory replicates, was assessed with the coefficient of variation $(\mathrm{CV})$ :

$$
C V_{\left[x_{l}\right]}=\frac{S_{\left[x_{l}\right]}}{\overline{\left[x_{l}\right]}} \times 100
$$

where

$$
\begin{gathered}
C V_{\left[x_{l}\right]} \quad \begin{array}{c}
\text { is the coefficient of variation for concentration } \\
\text { of chemical } x \text { in a liquid sample, }
\end{array} \\
S_{\left[x_{l}\right]} \quad \begin{array}{l}
\text { is the standard deviation for concentration of } \\
\text { chemical } x \text { in a liquid sample, and }
\end{array} \\
\overline{\left[x_{l}\right]} \quad \begin{array}{l}
\text { is the sample mean for concentration of } \\
\text { chemical } x \text { in a liquid sample. }
\end{array}
\end{gathered}
$$

This statistic provided a measure of variation in a group of samples independent of the magnitude of the mean, allowing for direct comparisons between results for different chemicals (Sokal and Rohlf, 1995).

Known-addition spikes were added to plant-tissue extract, soil extract, and water samples immediately before ELISA analysis to test for interferences between the sample matrix and the ELISA kits. The percent yield of knownaddition spikes in plant-tissue and soil-extract samples and in water samples was determined with the following equation:

$$
P Y_{\left[x_{l}\right]}=\frac{\left(\left[x_{l, s p}\right]-\left[x_{l, u}\right]\right)}{\frac{m_{s p}}{V_{l}}} \times 100
$$

where

$$
\begin{gathered}
P Y_{\left[x_{l}\right]} \quad \begin{array}{c}
\text { is the percent yield of chemical spike } x \text { in a } \\
\text { liquid sample; }
\end{array} \\
{\left[x_{l, s p}\right] \quad \begin{array}{r}
\text { is an ELISA-determined chemical } \\
\text { concentration in a spiked liquid sample, in } \\
\text { nanograms per liter; }
\end{array}} \\
\begin{aligned}
\left.x_{l, u}\right] \quad \text { is an ELISA-determined chemical } \\
\text { concentration in an unspiked liquid } \\
\text { sample, in nanograms per liter; }
\end{aligned} \\
\begin{aligned}
\text { is the mass of the chemical in the spike } \\
\text { solution added to the liquid sample, in } \\
\text { nanograms; and }
\end{aligned} \\
\quad \text { is the volume of liquid in which spiked } \\
\text { chemical concentration } x \text { was measured, in } \\
\text { liters. }
\end{gathered}
$$

The minimum reporting level (MRL) was not used to censor the calculated concentrations for the $\mathrm{CV}$ or the percent yield calculations. The MRL is the smallest concentration of a constituent that may be reported reliably by using a given analytical method (Timme, 1995). The use of noncensored calculated concentrations for the CV ensured that the variability in computed concentrations was reduced for concentrations greater than the MRL compared to computed concentrations less than the MRL. In the case of known-addition spikes, the use of noncensored calculated concentrations corrects the measured spiked sample concentration for the "background" matrix effects. In cases where the relative percent absorbance, $A_{r}$, was out of range of the calibration equation $\left[A_{r}\right.$ greater than $(>) 100$ percent, equation 1 and equations 10,12 , and 14 in appendix 3], the measured concentration was assumed to be zero.

\section{Soil and Plant-Tissue Extractions}

The concentrations of SMZ, SMX, and 17BE determined with the ELISA kits in the plant-tissue and soil extracts were converted to nanograms of chemical per gram of plant tissue or soil and to milligrams of chemical per plot area, according to the following calculations. First, the chemical (SMZ, SMX, or $17 \mathrm{BE})$ mass in nanograms per gram of solid sample $(\mathrm{ng} / \mathrm{g})$ was computed according to the following equation:

$$
\left[x_{s}\right]=\frac{\left[x_{l}\right] \times d \times V_{e}}{m_{s}}
$$


where

$$
\begin{gathered}
{\left[x_{s}\right] \quad \begin{array}{c}
\text { is the chemical concentration in a solid matrix } \\
\text { sample (plant tissue or soil), in nanograms } \\
\text { per gram; }
\end{array}} \\
\begin{array}{c}
\left.x_{l}\right] \quad \text { is an ELISA-determined chemical } \\
\text { concentration in liquid extract solution, in } \\
\text { nanograms per liter; }
\end{array} \\
d \quad \text { is the dilution factor (unitless); } \\
V_{e} \quad \text { is the total volume of extract solution, in } \\
\text { terms of post-evaporative volume, in } \\
\text { milliliters (a detailed explanation for this } \\
\text { variable is in appendix 3, equation 15); and } \\
m_{s} \quad \begin{array}{l}
\text { is the mass of dried solid sample material } \\
\text { used in the extraction, in grams. }
\end{array}
\end{gathered}
$$

The percent yield of the spike chemical mass of each spiked/unspiked pair of plant-tissue and soil-extract samples was calculated according to the following equation:

$$
P Y_{\left[x_{s}\right]}=\frac{\left(\left[x_{s, s p}\right]-\left[x_{s, u}\right]\right)}{\left(\frac{m_{s p}}{m_{s}}\right)} \times 100
$$

where

$$
\begin{array}{cl}
P Y_{\left[x_{s}\right]} & \begin{array}{c}
\text { is the percent yield of spike chemical mass in } \\
\text { solid matrix sample } x ;
\end{array} \\
{\left[x_{s, s]}\right]} & \text { is an ELISA-determined chemical } \\
& \text { concentration in spiked solid matrix } \\
& \text { sample } x \text {, in nanograms per gram, as } \\
& \text { calculated by equation 4; } \\
& \text { is an ELISA-determined chemical } \\
& \text { concentration in unspiked solid matrix } \\
& \text { sample } x \text {, in nanograms per gram, as } \\
& \text { calculated by equation 4; } \\
& \text { is the mass of the chemical in the spike added } \\
& \text { to the solid sample, in nanograms; and } \\
\left.m_{s, u}\right] & \text { is the mass of dried solid sample material } \\
& \text { used in the extraction, in grams. }
\end{array}
$$

The MRL was not used to constrain the concentrations used for this calculation; even if the calculated concentration of an unspiked sample was less than the MRL, the estimated concentration was used for this calculation. In cases where the $A_{r}$ was out of range of the calibration equation $\left(A_{r}>100\right.$, equation 1 and equations 10,12, and 14 in appendix 3), the measured concentration was assumed to be zero for determination of percent yield. These spikes essentially were a form of a known-addition spike, and equation 5 corrected the measured spike mass recovery for the "background" matrix effects.

The areal concentration of each chemical was computed to compare the fate of the chemicals in plant tissue and soil among land-cover treatments. For these computations, field samples with a concentration less than the MRL for a given chemical were assigned a concentration value of zero for that chemical. Because nonparametric rank-based statistical tests were used to compare treatment groups, a zero value appropriately ensured the rank of a nondetection was lower than that of a detection.

The areal concentration of chemicals in plant tissue was determined with the following equation:

$$
\left[x_{A, p}\right]=\frac{\left(\frac{\left[x_{s, u}\right]}{P Y_{\left[x_{s}\right]}}\right) \times r \times B}{10,000}
$$

where

$$
\begin{aligned}
& {\left[x_{A, p}\right] \quad \text { is the areal concentration of a chemical in }} \\
& \text { dry plant tissue, in milligrams per square } \\
& \text { meter; } \\
& {\left[x_{s, u}\right] \quad \text { is an ELISA-determined chemical }} \\
& \text { concentration in unspiked solid matrix } \\
& \text { sample } x \text {, in nanograms per gram; } \\
& P Y_{\left[x_{s}\right]} \quad \text { is the percent yield of spike, calculated in } \\
& \text { equation } 5 \text {; } \\
& r \quad \text { is the ratio of dry biomass weight to fresh } \\
& \text { biomass weight determined in the } \\
& \text { subsample; and } \\
& B \quad \text { is the total harvested fresh biomass per unit } \\
& \text { area, in grams per square meter. }
\end{aligned}
$$

The $r$ term was not determined for the June 2009 samples and so the term from the August 2009 plant-tissue sampling was assigned to the June 2009 sampling by plot. Soil-water content, air temperature, and relative humidity data collected at CCESR indicated similar moisture conditions in June and August (Cedar Creek Ecosystem Science Reserve, 2010).

Areal concentrations in soil were computed with the following equation:

$$
\left[x_{A, s o}\right]=\left(\frac{\left[x_{s, u}\right]}{P Y_{\left[x_{s}\right]}}\right) \times \rho_{B} \times D
$$

where

$$
\begin{aligned}
& {\left[x_{A, s o}\right] \quad \text { is the areal concentration of a chemical in }} \\
& \text { soil, in milligrams per square meter; } \\
& P Y_{\left[x_{s}\right]} \quad \text { is the percent yield of spike, as calculated in } \\
& \text { equation 5; } \\
& {\left[x_{s, u}\right] \quad \text { is an ELISA-determined chemical }} \\
& \text { concentration in unspiked solid sample } x \text {, } \\
& \text { in nanograms per gram; } \\
& \rho_{B} \quad \text { is the dry bulk density of soil, in grams per } \\
& \text { cubic centimeter; and } \\
& D \quad \text { is the depth of the soil sample, in centimeters. }
\end{aligned}
$$

\section{Statistics}

Nonparametric statistical tests were completed with the statistical software package, R (R Development Core Team, 2011). Kruskal-Wallis rank sum tests (Helsel and Hirsch, 2002) were used to test for significant differences in distribution among experimental treatments with respect to the 
total fresh biomass $(B)$ at the time of sampling and the areal concentrations of each chemical in soil, $\left[x_{A, s o}\right]$, and plant tissue, $\left[x_{A, p}\right]$. Kruskal-Wallis tests also were done to identify significant differences among land-cover treatments with respect to ancillary datasets, including root biomass to $30 \mathrm{~cm}$ below land surface, time between spray application and soil sampling, and soil $\mathrm{pH}$ and moisture at the time of soil sampling. For comparisons of areal SMZ and SMX concentrations, independent Kruskal-Wallis tests were done for each chemical and sample matrix combination. For example, independent Kruskal-Wallis tests were done for SMZ in soil, SMZ in plants, SMX in soil, and so forth. A Kruskal-Wallis rank sum test also was used to test each chemical-matrix combination for significant differences in distribution of the spike percent yield in solid samples $P Y_{\left[x_{s}\right]}$. Any Kruskal-Wallis test that indicated a significant difference in distribution at an alpha level of 0.05 , or marginal significance at an alpha level greater than 0.05 but less than 0.10 , was followed with a post-hoc, nonparametric Tukey Honest Significant Difference (HSD) test to determine which treatment(s) produced significantly different observations (Higgins, 2004).

Measurements of areal concentration were made in plant tissue $\left(\left[x_{A, p}\right]\right)$ in June 2009 and August 2009 and soil $\left(\left[x_{A, s o}\right]\right)$ in April 2009 and June 2009 (table 2). The temporal change in the areal concentration of each chemical in plant tissue $\left(\Delta\left[x_{A, p}\right]\right)$ and soil $\left(\Delta\left[x_{A, s o}\right]\right)$ was calculated for each plot by subtracting the value at the first sampling from the value at the second sampling. A two-sided Wilcoxon signed rank test was used to test the null hypothesis that the distributions of the temporal changes in plants $\left(\Delta\left[x_{A, p}\right]\right)$ and soils $\left(\Delta\left[x_{A, s o}\right]\right)$ were symmetric about zero (Hollander and Wolfe, 1973). A significant test at an alpha of 0.05 [ $p$-value less than $(<) 0.05$ ] indicated that the temporal changes were directional, shifted away from zero. A $p$-value between 0.05 and 0.10 was considered marginally significant. A separate test was done for each combination of crop type, sample matrix, and chemical.

Kendall's tau was used to test for significant monotonic relations between areal concentrations of SMZ and SMX, and ancillary data including soil $\mathrm{pH}$, gravimetric soil-water content, and length of time between spray application and soil sample collection in April 2009 (Helsel and Hirsch, 2002).

\section{Soil Hydrology}

Detailed analyses were done to assess the effects of land cover on the flow of water and solutes through the soil profile to groundwater in the plots of this experiment (Trost, 2010). A soil-water balance, water-table hydrograph analysis, and chemical analysis of a bromide tracer in pore water in the unsaturated and saturated zones were used to identify differences in rates and amounts of water and solute movement through the soil profile underlying perennial and annual landcover types (Trost, 2010). Soil-water storage and precipitation were measured directly. Using data from one plot for each treatment, percolation below the rooting zone was estimated based on the relation between soil-moisture loss and moisture content at $200 \mathrm{~cm}$ below land surface. Data for these calculations were collected during periods of nonfrozen soil and low evapotranspiration (ET). Estimates of ET were determined by difference in the other water-balance terms. The details of the assumptions and calculations are presented in Trost (2010).

\section{Quality Assurance}

The primary data-quality objectives were to ensure that (1) water, soil, and plant-tissue samples were representative of the plots under investigation and (2) SMZ, SMX, and 17BE could reliably be detected and quantified in plant-tissue, soil, and water samples with ELISA kits. Blank water and replicate samples were collected in the field to assess sampling and sample-processing procedures. Analyses of laboratory blank water samples, spiked samples, and field and laboratory replicates were used to assess the accuracy and precision of ELISA kits for quantification of SMZ, SMX, and 17BE in plant-tissue, soil, and water samples.

The effectiveness of equipment cleaning and sample processing was assessed by analysis of field and laboratory blanks with ELISA kits. Laboratory deionized water or organic-free blank water was processed in the field or in the laboratory with the same collection bottles, filtering devices, and methods as were used for environmental water sample collection.

Sequential or split replicate samples of soil-water and groundwater samples were collected to assess variability among samples resulting from sample collection, processing, and laboratory procedures done at different sampling times (U.S. Geological Survey, variously dated). A sequential replicate sample was collected consecutively following the collection of the regular sample. A split replicate sample was derived from the regular sample by dividing the sample material into two or more independent sample containers (U.S. Geological Survey, variously dated). One sequential replicate groundwater sample was collected for bromide analysis at the USGS National Water Quality Laboratory. Split replicate samples of soil water and groundwater were collected for analysis by ELISA kits for SMZ, SMX, and 17BE. Additionally, field samples of each medium type (plant tissue, soil, soil water, and groundwater) were analyzed two or more times to assess variability in the ELISA analytical techniques.

The sequential and split replicate sample results were compared by calculating the relative percent difference (RPD) for each detected concentration pair by using the equation

$$
R P D=\frac{\left|C_{1}-C_{2}\right|}{\left(\frac{\left(C_{1}+C_{2}\right)}{2}\right)} \times 100
$$


where

$$
\begin{aligned}
& C_{1} \quad \begin{array}{l}
\text { is the detected concentration in the split or } \\
\text { sequential replicate sample, and }
\end{array} \\
& C_{2} \quad \begin{array}{l}
\text { is the detected concentration in the split } \\
\text { replicate or environmental sample. }
\end{array}
\end{aligned}
$$

\section{Enzyme-Linked Immunosorbent Assay (ELISA)}

Several check standards were analyzed with every ELISA kit used to assess the accuracy and precision of SMZ, SMX, and 17BE quantification within and between kits. These check standard samples included at least one laboratory deionized water blank, a mid-range "kit control" check standard from Abraxis, and laboratory-generated low-range and high-range check standards (table 4). The inclusion of laboratory-generated check standards provided information about the method performance across all ELISA kits used for each chemical. Summaries of these quality-assurance sample determinations for each chemical are presented in figure 4 and table 5 .

The accuracy and precision of measurements of SMZ, SMX, and 17BE concentrations in environmental samples with ELISA kits were assessed through known-addition spikes and replicate determinations of plant-tissue extract, soil extract, and unspiked and spiked water samples within and across kits. Known-addition spikes were added to plant-tissue extract, soil extract, and water samples immediately before ELISA analysis to test for interferences between the sample matrix and the ELISA kits (eq. 3; table 6). The coefficient of variation (CV) was calculated (eq. 2) for all replicate analyses of the same sample. Because all field and laboratory replicate analyses were combined for this calculation, the $\mathrm{CV}$ represents a pooled assessment of precision for the entire sampling and analytical process (fig. 5; table 7). This means the variability resulting from field sampling techniques, sample storage, and laboratory analytical processes are all pooled in the CV estimate; the specific contribution of each process to result variability was not determined.

The median percent yields (recoveries) of SMZ, SMX, and $17 \mathrm{BE}$ in known-addition spike samples ranged from 75 to 131 percent in plant-tissue extracts, soil extracts, and soilwater and groundwater samples (table 6). The only exception to this was the median 17BE concentration in soil extract, in which 205 percent of the known-addition spike was recovered. For this particular matrix-chemical combination, only one determination of spike percent yield was made. This single 17BE determination is not evidence of a consistent overestimation bias. Determinations of the percent yield of 17BE spikes added to soil samples before the extraction process did not indicate a similar overestimation of 17BE (fig. $6 F$ ). Determinations of known-addition spike recovery were not done for every sample and were therefore not used to adjust measured concentrations of any chemical in any samples.

Repeated measurements of SMX and 17BE concentrations in soil-water and groundwater samples were among the most variable of any sample medium measured for these chemicals (fig. 5B,C; table 7). Repeated measurements of SMZ concentrations in plant-tissue extracts generally had higher CVs than measurements of SMZ in water samples

\begin{tabular}{|c|c|c|c|}
\hline \multirow{2}{*}{ Description } & Sulfamethazine & Sulfamethoxazole & 17-beta-Estradiol \\
\hline & \multicolumn{3}{|c|}{ Concentration, in ng/L } \\
\hline Abraxis kit calibration standards ${ }^{\mathrm{a}}$ & 50,500 , and 5,000 & $25,50,100,250$, and 1,000 & $2.5,7.5$, and 25.0 \\
\hline Abraxis kit control standards & 1,000 & 200 & 10 \\
\hline Low-level check standard & 50 or 250 & 50 & 2.5 \\
\hline $\begin{array}{l}\text { Water sample minimum } \\
\text { reporting level }\end{array}$ & $\begin{array}{l}\text { the greater of } 32 \mathrm{ng} / \mathrm{L} \text { or the } \\
\text { calculated concentration at } \\
90 \text { percent of the } 0 \text { standard } \\
\text { absorbance }\end{array}$ & $\begin{array}{l}\text { the greater of } 25 \mathrm{ng} / \mathrm{L} \text { or the } \\
\text { calculated concentration at } \\
90 \text { percent of the } 0 \text { standard } \\
\text { absorbance }\end{array}$ & $\begin{array}{l}\text { the greater of } 2.5 \mathrm{ng} / \mathrm{L} \text { or the } \\
\text { calculated concentration at } \\
90 \text { percent of the } 0.0 \text { standard } \\
\text { absorbance. }\end{array}$ \\
\hline
\end{tabular}

Table 4. Concentrations of calibration standards and check standards used with enzyme-linked immunosorbent assay (ELISA) kits, and minimum reporting levels (MRL) for plant-tissue, soil, and water samples for sulfamethazine, sulfamethoxazole, and 17-beta-estradiol.

[ng/L, nanograms per liter]

${ }^{a}$ Only the nonzero standards are listed. 
A. Sulfamethazine (SMZ) concentrations in blanks, calibration standards, and check standards

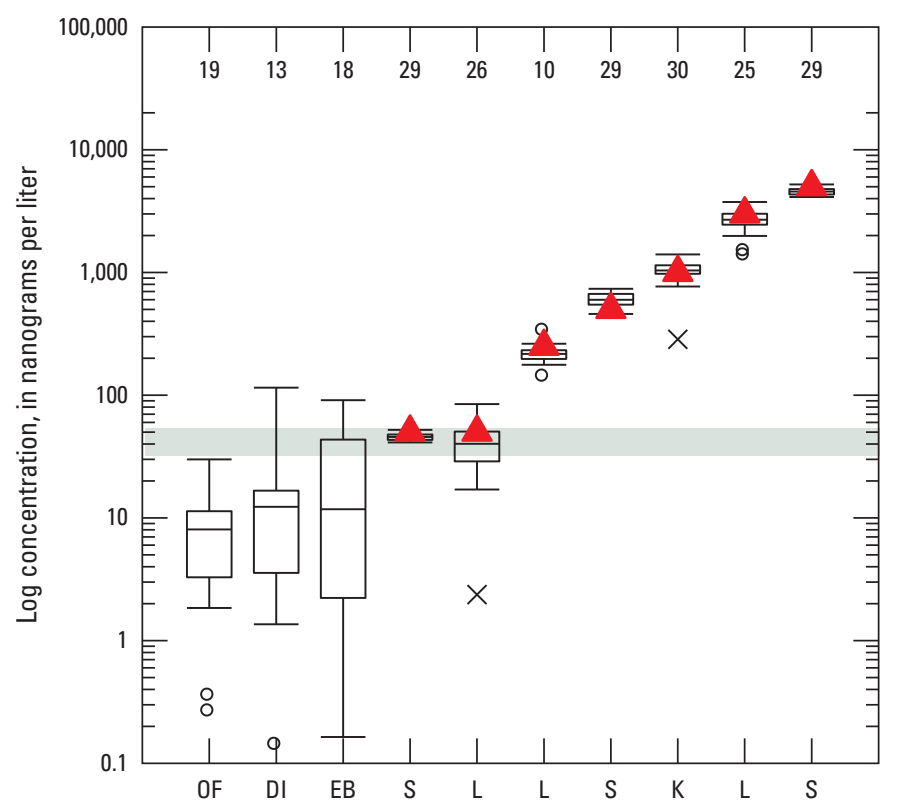

C. 17-beta-estradiol (17BE) concentrations in blanks, calibration standards, and check standards

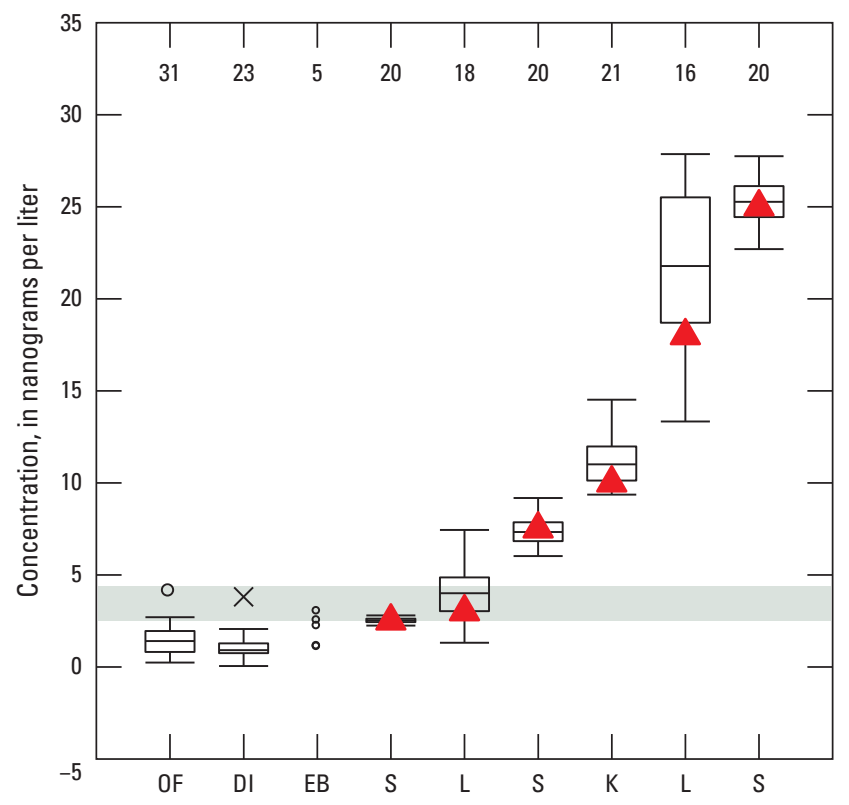

B. Sulfamethoxazole (SMX) concentrations in blanks, calibration standards, and check standards

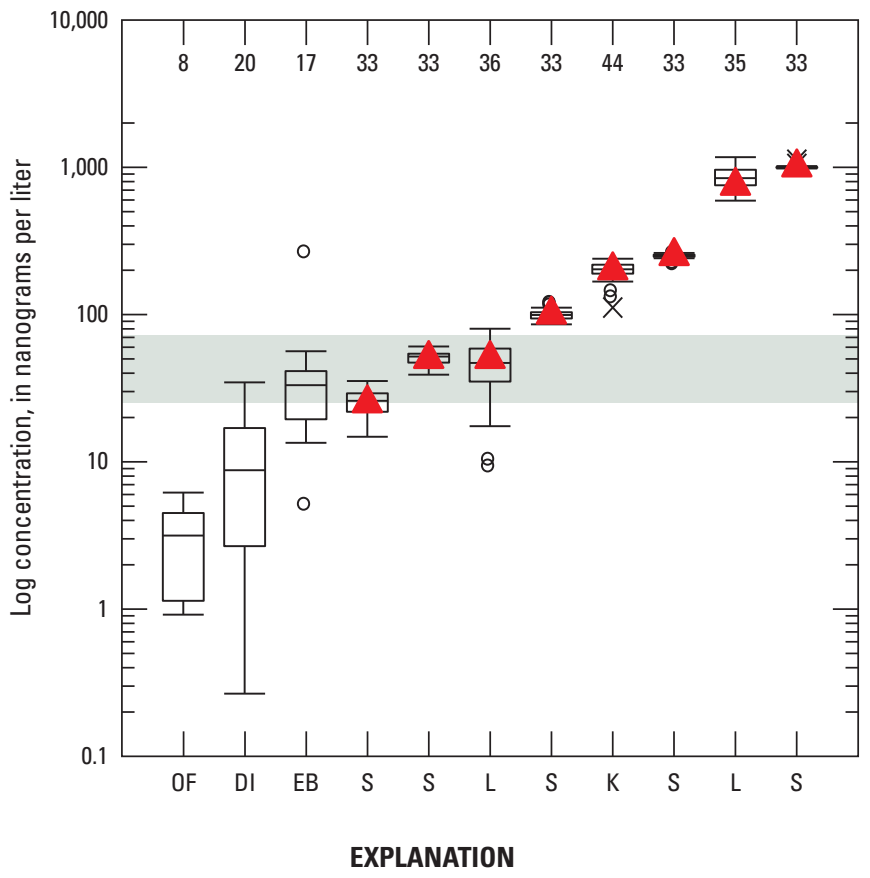

Minimum reporting level range

$\triangle \quad$ Calibration and check standard expected concentrations

Abbreviations

Organic-free blank water

Laboratory deionized blank water

Citric acid extract buffer blank

Abraxis calibration standard

Laboratory-generated check standard

Abraxis check standard

Samples out of range of a kit's calibration equation (a relative percent absorbance greater than 100 percent, $A_{r}$ in equation 1) are excluded from these plots.

20 Number of values

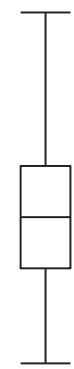

Largest value within 1.5 times interquartile range above 75th percentile

\section{5th percentile}

50th percentile (median) Interquartile range

25th percentile

Smallest value within 1.5 times interquartile range below 25th percentile

- Outside value - Value is greater than 1.5 and less than 3 times the interquartile range beyond either end of box

$\times \quad$ Far-out value - Value is greater than or equal to 3 times the interquartile range beyond either end of box

Figure 4. Boxplots of concentrations, measured with enzyme-linked immunosorbent assays (ELISA), in blanks, calibration standards, and check standards for $A$, sulfamethazine (SMZ); $B$, sulfamethoxazole (SMX); and $C$, 17-beta-estradiol (17BE). 
(fig. 5A). For all three chemicals, the $\mathrm{CV}$ of the Abraxis check standard across all runs was lower than the CV of the laboratory check standards and most environmental samples. Of the environmental sample mediums (plant tissue, soil, soil water and groundwater), soil samples tended to have the lowest CVs.

Minimum reporting levels (MRLs) of SMZ, SMX, and 17BE concentrations were determined for all samples based on the performance of each ELISA kit and associated qualityassurance data. For this report, the MRL for each matrix and chemical combination (table 4) is representative of the entire process from field sample collection through sample analysis, not just the limitation of the ELISA kits. The MRL for each matrix and chemical combination was within the manufacturer's guidelines and minimized false negative and false positive determinations by each kit. This approach for determining MRLs also resulted in lower CVs for samples with mean concentrations greater than the MRL compared to samples with mean concentrations less than the MRL (fig. 5; table 7).

Additional quality-control measures were implemented specifically for solid matrix extract (plant tissue and soil) samples. Each extract sample was analyzed as a spiked-unspiked pair to assess the yield of each chemical through the processes of extraction and ELISA analysis (eq. 5). At least one blank sample of citric acid extract buffer was analyzed with each run of soil and plant-tissue samples to assess possible interference between the ELISA kit and the extract solution.

The individual data values for internal lab assessments of ELISA kit performance, including Abraxis-supplied calibration standards, laboratory-generated check standards, Abraxissupplied check standards, laboratory-generated spikes, and laboratory-generated blanks (deionized water, organic-free water, and citric acid extract buffer), that were analyzed with each kit run are not included in table 4-2 in appendix 4; however, these internal lab quality-assurance data are summarized along with the field and sample processing quality-assurance data in figures 4 and 5 and tables 5, 6, and 7 .

\section{Soil and Plant-Tissue Extract Samples}

SMZ and SMX were detected more frequently at concentrations greater than the MRL in blank samples of the citric acid extract buffer compared to the other laboratory blank samples, an indication of possible contamination or interference between the citric acid buffer solution and ELISA kits (table 5). SMZ was detected in 6 of 18 analyses of citric acid extract buffer blanks, and SMX was detected in 6 of 19 analyses of citric acid extract buffer blanks (table 5). For SMZ and SMX, four of the detections were less than or equal to 50 nanograms per liter (ng/L).

The spike percent yield (recovery) of SMZ, SMX, and $17 \mathrm{BE}$ in spiked samples through the extraction procedure generally was higher in soil samples compared to planttissue samples (fig. 6). Of the three chemicals, recoveries of SMZ were most reasonable (near 100 percent) in plant-tissue samples, and recoveries of SMX were most reasonable in soil samples. A Kruskal-Wallis rank sum test indicates no statistically significant difference in the spike percent yield among land-cover types within each chemical-matrix combination ( $p$-values all greater than 0.10 , table 8 ; fig. 6). Because of the variability in the spike percent yield between samples, all chemical concentrations in environmental samples of plant tissue and soil were adjusted by the spike percent yield for data analysis (eqs. 6 and 7).

\section{Water Samples}

Minimum reporting levels (MRLs) for each ELISA kit were assigned according to a protocol designed to minimize false positive detections (table 4). The chemical concentration in an environmental sample was inversely proportional to color development. The criteria for assigning reporting levels required that, to qualify as a detection, an environmental water sample must have caused at least a 10-percent reduction in absorbance compared to the zero standard supplied with each kit. For SMZ, the MRL was determined to be the greater of either the manufacturer's method detection limit $(32 \mathrm{ng} / \mathrm{L})$ or the calibration equation-predicted concentration of chemical at 90 percent of the zero standard absorbance. For the SMX and $17 \mathrm{BE}$ kits, the MRL was determined to be the greater of either the kit's lowest calibration standard concentration or the calibration equation-predicted concentration of chemical at 90 percent of the zero standard absorbance.

Under these reporting level criteria, detections of each chemical in blank samples were rare (including all blanks, internal laboratory blanks and field and sample-processing blanks). Only the blanks within the range of the calibration equation for each kit are presented in figure 4. A tabular summary of all of the data is given in table 5, which includes samples with a measured absorbance out of range of the calibration equations. In these cases, where the calculated relative percent absorbance ( $A_{r}$, eq. 1$)$ of a sample was greater than 100 percent, a concentration of 0 was assigned. Field and sample-processing blank data are given in appendix 4 . The antibiotic SMZ was detected at concentrations greater than the MRL in 2 of 26 deionized water blanks (90 and $120 \mathrm{ng} / \mathrm{L}$ ) and in none of 39 organic-free laboratory and field blanks (fig. 4A; table 5). The antibiotic SMX was not detected in concentrations greater than the MRL in any field or laboratory blanks of deionized water (42 samples) or organic-free blank water (40 samples) (fig. 4B; table 5). The hormone $17 \mathrm{BE}$ was detected at concentrations greater than the MRL in 1 of 25 laboratory deionized water blanks (3.8 ng/L, fig. $4 C$; table 5). The hormone $17 \mathrm{BE}$ was detected in 2 of 33 organicfree field blanks, $2.7 \mathrm{ng} / \mathrm{L}$ (fig. 4C; table 4-2 in appendix 4) and $4.3 \mathrm{ng} / \mathrm{L}$ (fig. $4 C$; table 5 ).

The measured concentrations of SMZ were greater than the MRL in 17 of 26 determinations of the $50 \mathrm{ng} / \mathrm{L}$ laboratory check standard solution. The 9 nondetections indicate a false nondetection rate of 35 percent under the data-censoring criteria established for this study. Therefore, it is probable that approximately 1 in 3 environmental samples could be misclassified as a nondetection when the actual sample SMZ 


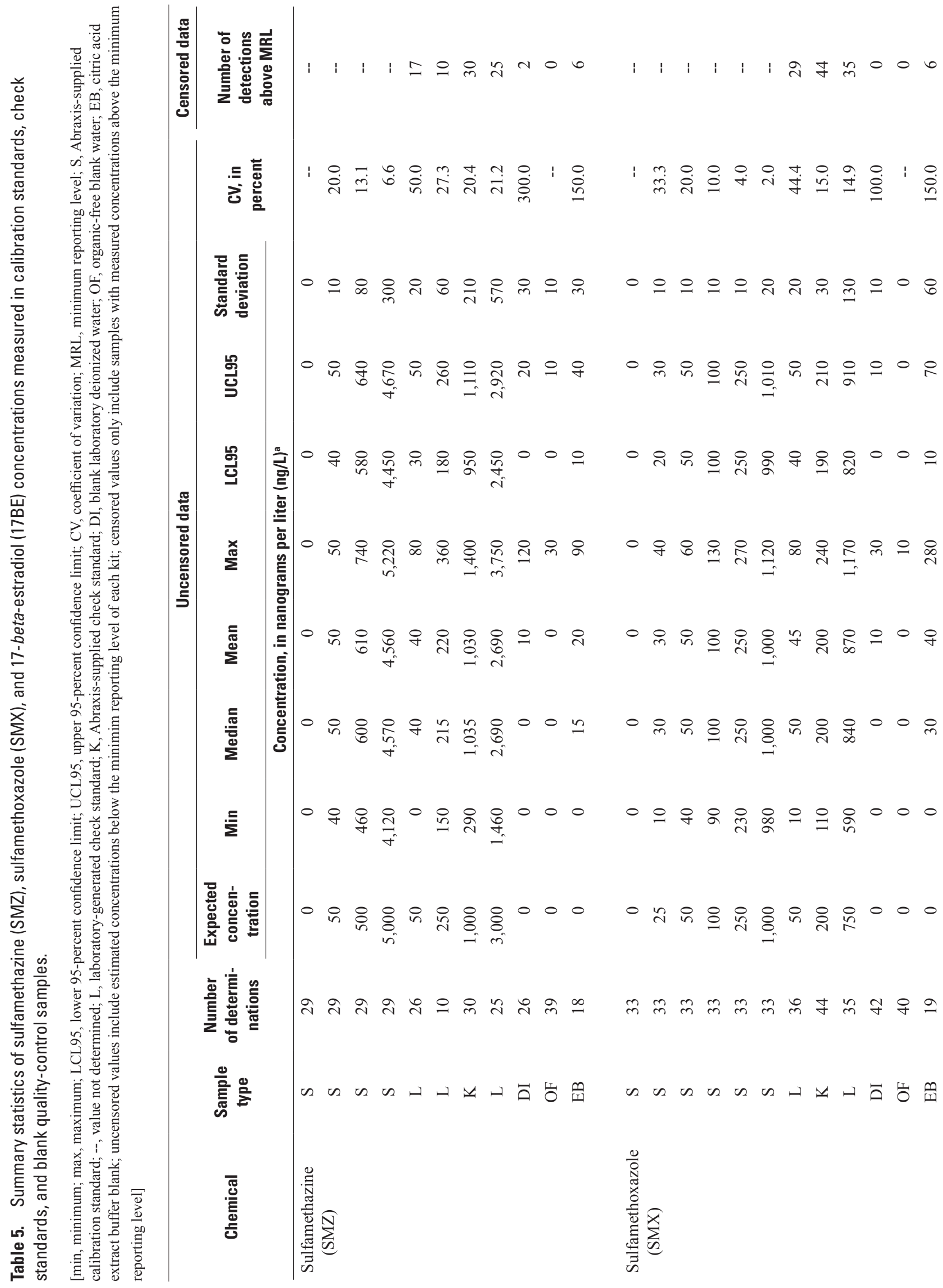




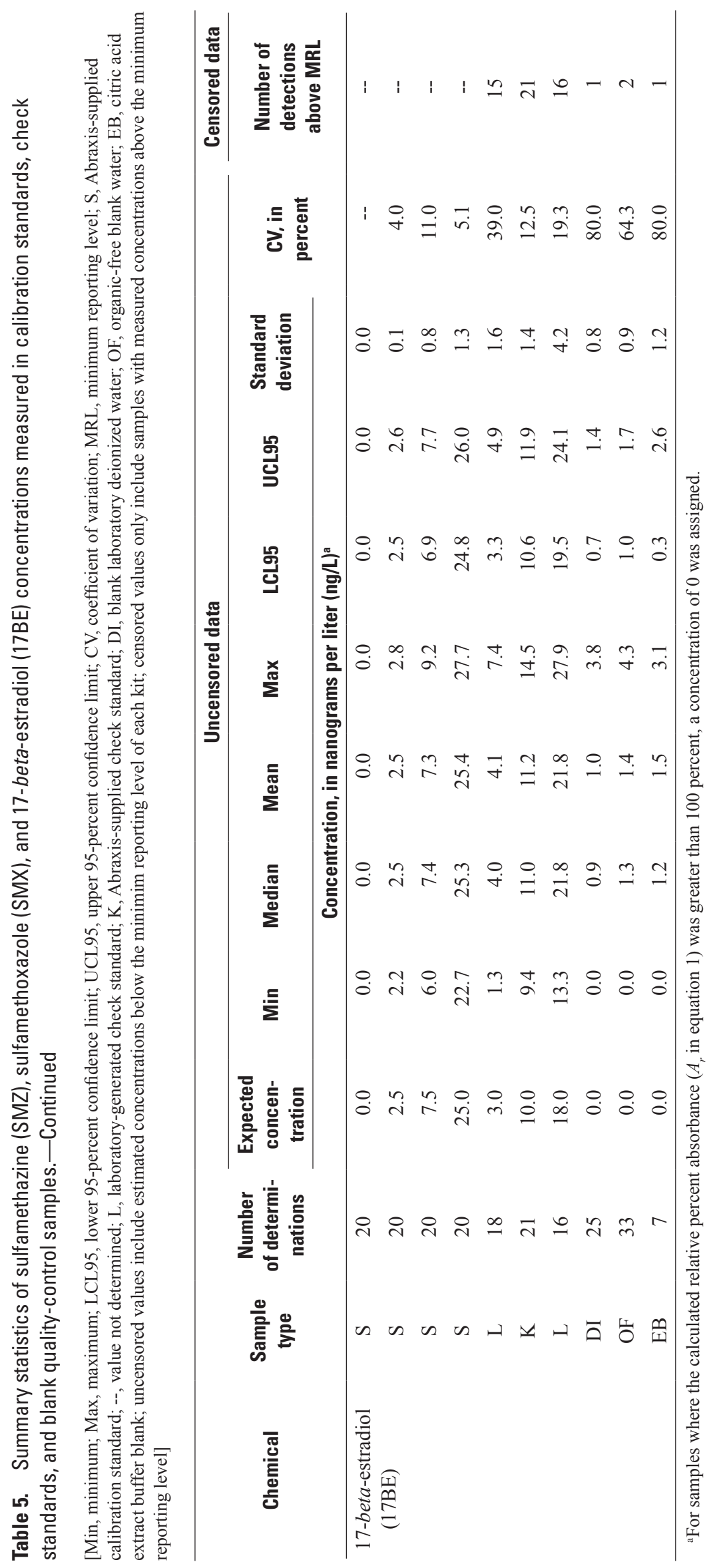


Table 6. Summary statistics of percent yields (spike recoveries) of chemicals in known-addition spike samples for deionized water, citric acid extract buffer, plant-tissue extract, soil extract, soil-water, and groundwater samples spiked immediately prior to enzymelinked immunosorbent assay (ELISA) analysis.

[min, minimum value; max, maximum value; --, value not determined]

\begin{tabular}{|c|c|c|c|c|c|c|c|}
\hline \multirow[b]{2}{*}{ Chemical } & \multirow{2}{*}{$\begin{array}{c}\text { Expected spike } \\
\text { concentration, } \\
\text { in nanograms } \\
\text { per liter }\end{array}$} & \multirow[b]{2}{*}{ Sample medium } & \multirow{2}{*}{$\begin{array}{c}\text { Number of } \\
\text { determinations }\end{array}$} & \multicolumn{4}{|c|}{ Percent yield } \\
\hline & & & & Min & Median & Mean & Max \\
\hline \multirow{3}{*}{$\begin{array}{l}\text { Sulfamethazine } \\
\quad \text { (SMZ) }\end{array}$} & \multirow[t]{3}{*}{500} & Plant-tissue extract & 6 & 14 & 118 & 106 & 171 \\
\hline & & Soil extract & 5 & 11 & 90 & 74 & 114 \\
\hline & & Soil water and groundwater & 3 & 69 & 107 & 102 & 130 \\
\hline \multirow{5}{*}{$\begin{array}{l}\text { Sulfamethoxazole } \\
\quad \text { (SMX) }\end{array}$} & \multirow[t]{5}{*}{500} & Citric acid extract buffer & 1 & -- & 99 & -- & -- \\
\hline & & Deionized water & 1 & -- & 109 & -- & -- \\
\hline & & Plant-tissue extract & 7 & 49 & 104 & 92 & 113 \\
\hline & & Soil extract & 5 & 59 & 83 & 81 & 100 \\
\hline & & Soil water and groundwater & 14 & 117 & 131 & 132 & 164 \\
\hline \multirow{3}{*}{$\begin{array}{l}\text { 17-beta-estradiol } \\
\text { (17BE) }\end{array}$} & \multirow[t]{3}{*}{10} & Plant-tissue extract & 2 & 74 & 75 & 75 & 76 \\
\hline & & Soil extract & 1 & -- & 205 & -- & -- \\
\hline & & Soil water and groundwater & 12 & 57 & 120 & 120 & 222 \\
\hline
\end{tabular}

concentration is between the MRL and $50 \mathrm{ng} / \mathrm{L}$. The mean and 95 -percent confidence interval of the 26 determinations of the $50-\mathrm{ng} / \mathrm{L}$ check standard was 40 plus or minus $( \pm) 10 \mathrm{ng} / \mathrm{L}$, including calculated concentrations greater than (detections) and less than (nondetections) the MRL.

The measured concentrations of SMX were greater than the MRL in 29 of 36 determinations of the $50-\mathrm{ng} / \mathrm{L}$ laboratory check standard solution. The 7 nondetections indicate a false nondetection rate of 19 percent under the data-censoring criteria established for this study. Therefore, it is probable that approximately 1 in 5 environmental samples could be misclassified as a nondetection when the actual sample SMX concentration is between the MRL and $50 \mathrm{ng} / \mathrm{L}$. The mean and 95-percent confidence interval of the 36 determinations of the $50 \mathrm{ng} / \mathrm{L}$ check standard was $45 \pm 5 \mathrm{ng} / \mathrm{L}$, including calculated concentrations greater than (detections) and less than (nondetections) the MRL.

The measured concentrations of $17 \mathrm{BE}$ were greater than the MRL in 15 of 18 determinations of the 3.0-ng/L laboratory check standard solution. The 3 nondetections indicate a false nondetection rate of 17 percent under the data-censoring criteria established for this study. Therefore, it is probable that approximately 1 in 6 environmental samples could be misclassified as a nondetection when the actual sample 17BE concentration is between the MRL and $3.0 \mathrm{ng} / \mathrm{L}$. The mean and 95-percent confidence interval of the 18 determinations of the 3.0-ng/L check standard was $4.1 \pm 0.8 \mathrm{ng} / \mathrm{L}$, including calculated concentrations greater than (detections) and less than (nondetections) the MRL.

\section{Bromide Analysis}

Quality-assurance procedures for determination of bromide concentrations in water samples at the USGS National Water Quality Laboratory were published by the U.S. Geological Survey (2013a). All of the water-quality data (including field quality-assurance samples) and sampling site information are stored in the USGS National Water Information System (NWIS) database (U.S. Geological Survey, 2013b).

The Orion 96-35 bromide electrode calibration was checked at least two times per day of use, once before and once after a series of environmental sample analyses (Thermo Fisher Scientific Incorporated, 2008). Bromide concentrations in split replicates of spiked samples that were analyzed at the National Water Quality Laboratory and with the Orion 96-35 probe agreed well. Samples with bromide concentrations of $1 \mathrm{mg} / \mathrm{L}$ or more had, at most, a 5-percent relative percent difference (data in table 4-5 in appendix 4). A summary of replicate and blank sample analyses completed at the National Water Quality Laboratory are available in table 9. Additional details of the Orion 96-35 electrode calibration and measurement procedures are presented in Trost (2010). 
A. Relation between coefficient of variation and mean sulfamethazine (SMZ) concentration

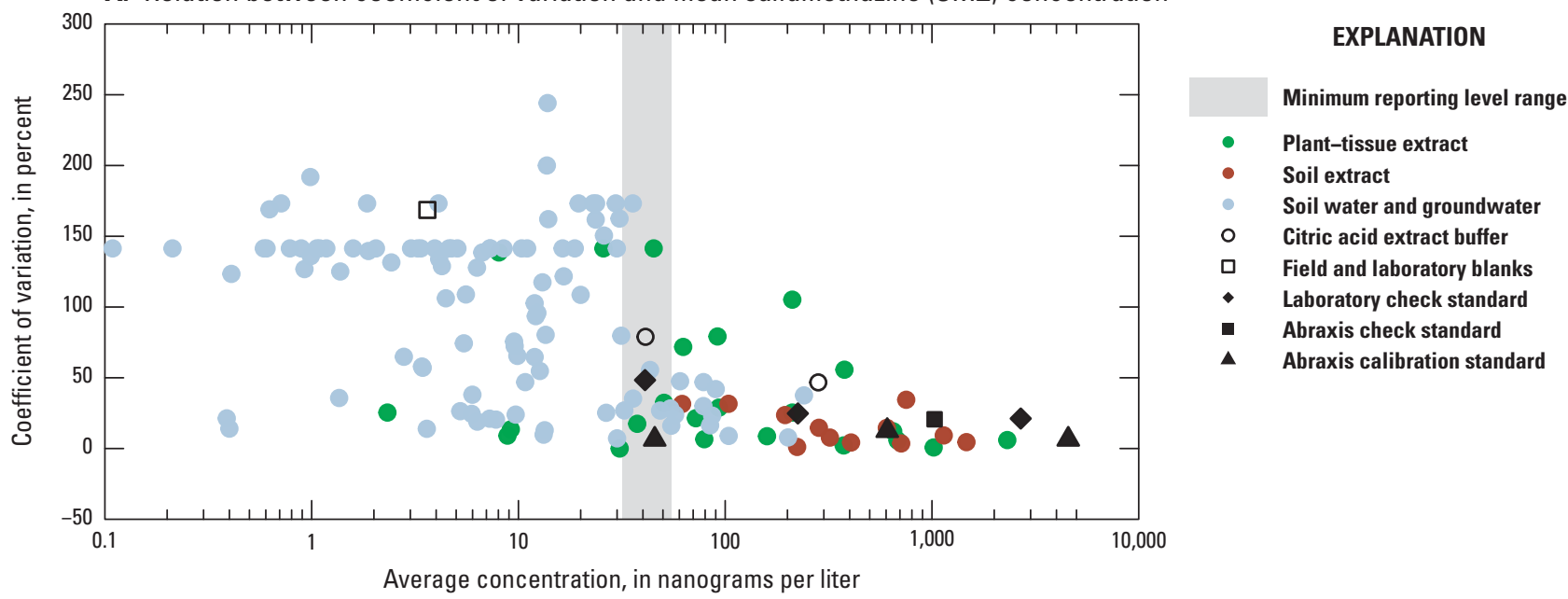

B. Relation between coefficient of variation and mean sulfamethoxazole (SMX) concentration

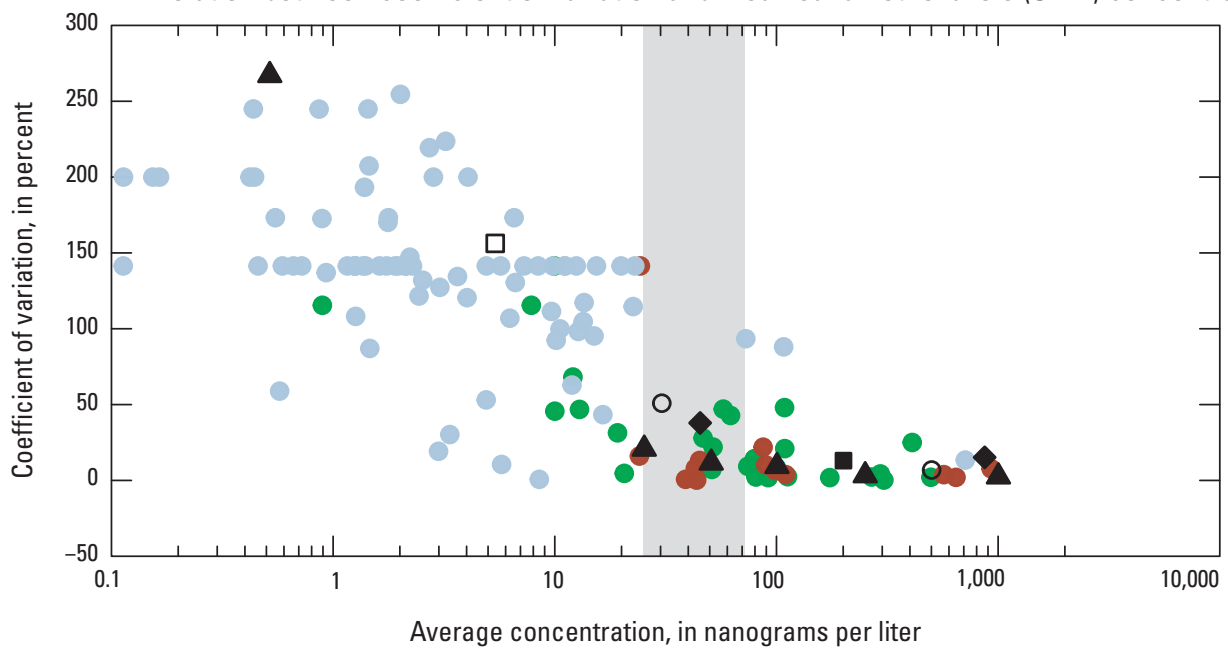

C. Relation between coefficient of variation and mean 17-beta-estradiol (17BE) concentration

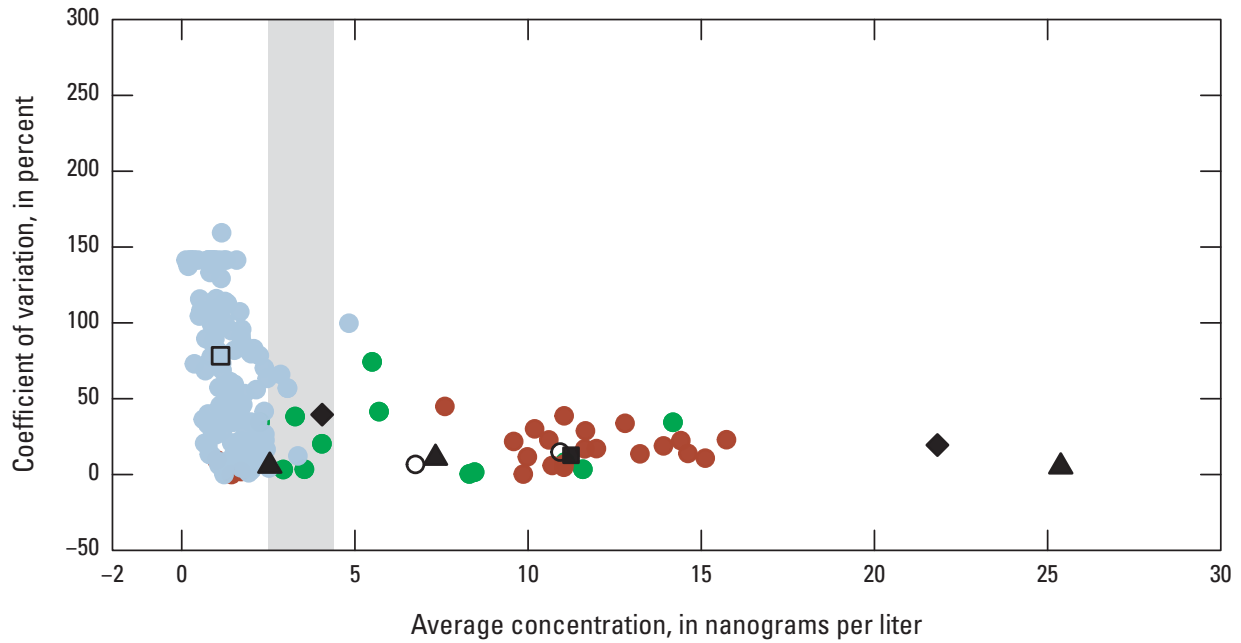

Figure 5. Relation between coefficient of variation and mean concentration, grouped by sample medium, for replicate enzyme-linked immunosorbent assay (ELISA) determinations in all field and laboratory samples of $A$, sulfamethazine (SMZ); $B$, sulfamethoxazole (SMX); and C, 17-beta-estradiol (17BE). 
Table 7. Summary statistics of coefficient of variation determinations for sulfamethazine, sulfamethoxazole, and 17-beta-estradiol for calibration standards, check standards, spiked extract buffer, plant-tissue extract, soil extract, and water samples with mean concentrations greater than the minimum reporting level.

[CV, coefficient of variation; --, value not determined]

\begin{tabular}{|c|c|c|c|c|c|c|}
\hline \multirow{2}{*}{ Chemical } & \multirow{2}{*}{ Sample medium } & \multirow{2}{*}{$\begin{array}{l}\text { Number of CV } \\
\text { determinations }\end{array}$} & \multicolumn{4}{|c|}{ Coefficient of variation, in percent } \\
\hline & & & Minimum & Median & Mean & Maximum \\
\hline \multirow{5}{*}{$\begin{array}{l}\text { Sulfamethazine } \\
\text { (SMZ) }\end{array}$} & Abraxis calibration standard (S) & 3 & 6.5 & 6.5 & 8.5 & 12.6 \\
\hline & Citric acid extract buffer blank (EB) & 2 & 46.7 & 62.8 & 62.8 & 78.9 \\
\hline & Abraxis check standard $(\mathrm{K})$ & 1 & -- & 20.7 & -- & -- \\
\hline & Soil extract & 12 & 1.1 & 11.9 & 15.1 & 34.5 \\
\hline & Water & 17 & 7.8 & 28.3 & 38.0 & 173.2 \\
\hline \multirow{4}{*}{$\begin{array}{l}\text { Sulfamethoxazole } \\
\qquad \text { (SMX) }\end{array}$} & Abraxis calibration standard (S) & 5 & 2.5 & 9.4 & 9.5 & 20.8 \\
\hline & Laboratory-generated check standard (L) & 2 & 15.2 & 26.5 & 26.5 & 37.9 \\
\hline & Soil extract & 11 & 0.2 & 6.5 & 7.1 & 21.9 \\
\hline & Water & 3 & 13.4 & 88.1 & 65.0 & 93.4 \\
\hline \multirow{6}{*}{$\begin{array}{l}\text { 17-beta-estradiol } \\
\quad(17 \mathrm{BE})\end{array}$} & Abraxis calibration standard (S) & 3 & 5.2 & 5.7 & 7.3 & 10.9 \\
\hline & Laboratory-generated check standard (L) & 2 & 19.4 & 29.5 & 29.5 & 39.5 \\
\hline & Citric acid extract buffer blank (EB) & 2 & 6.7 & 10.8 & 10.8 & 14.8 \\
\hline & Abraxis check standard $(\mathrm{K})$ & 1 & -- & 12.7 & -- & -- \\
\hline & Plant-tissue extract & 11 & 0.4 & 8.3 & 20.9 & 74.3 \\
\hline & Soil extract & 20 & 0.3 & 18.0 & 19.4 & 44.9 \\
\hline
\end{tabular}

\section{Land-Cover Effects on the Fate and Transport of Sulfamethazine, Sulfamethoxazole, and 17-beta- Estradiol}

Concentrations of SMZ, SMX, and 17BE measured with ELISA kits in plant-tissue, soil $(0-10 \mathrm{~cm})$, soil-water, and groundwater samples collected between October 2008 and October 2009 were used to compare the fate and transport of these chemicals through land-cover types of bare soil, corn, hay, and prairie (appendix 4). Areal concentrations of SMZ and SMX in soil decreased more in prairie plots from April 2009 to June 2009, compared to the other land-cover treatments. The areal concentrations of SMZ and SMX in the aboveground plant tissues in June 2009 and August 2009 were much lower, generally two to three orders of magnitude, than the areal concentrations of these chemicals in soil. Pooling all treatment plot data, the median areal concentration of SMZ and SMX in plant tissues was 0.01 and 0.10 percent of the applied chemical mass compared to 22 and 12 percent in soil, respectively. Furthermore, areal concentrations of SMZ and SMX in plant-tissue samples were variable, and did not differ significantly between control and treatment plots within each land-cover type.

SMZ was detected in 23 percent of soil-water samples and in 16 percent of groundwater samples from treatment plots, indicating SMZ leached below the rooting zone and reached groundwater. SMX was detected in only 1 percent of soil-water and groundwater samples from treatment plots. In contrast to the antibiotics, 17BE was not detected reliably in soil samples. Additionally, ELISA-determined 17BE concentrations in plant-tissue, soil-water, and groundwater samples indicated the presence of chemicals that were not applied as part of this experiment [17BE from an external source or other chemical(s) that interfered with the 17BE ELISA kits]. 
A. Sulfamethazine spike percent yield in plant-tissue extracts

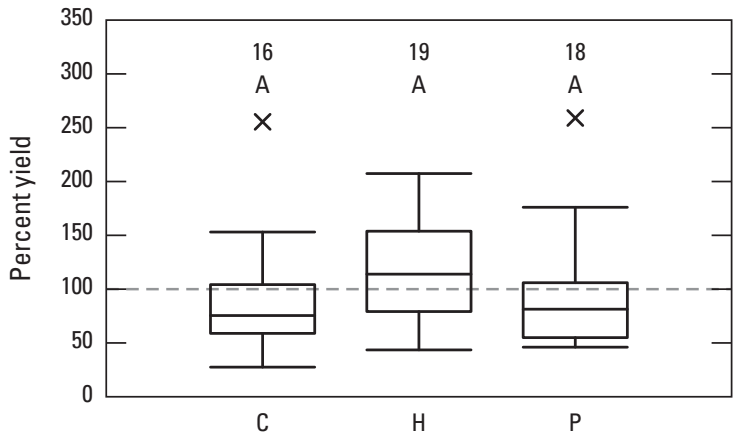

C. Sulfamethoxazole spike percent yield in plant-tissue extracts

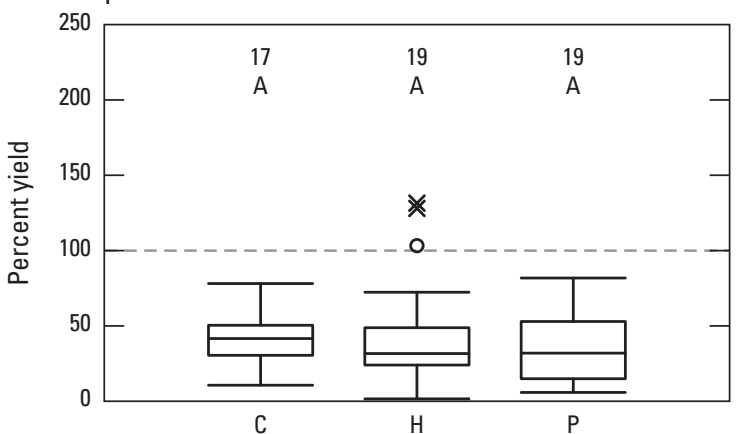

E. 17-beta-estradiol spike percent yield in plant-tissue extracts

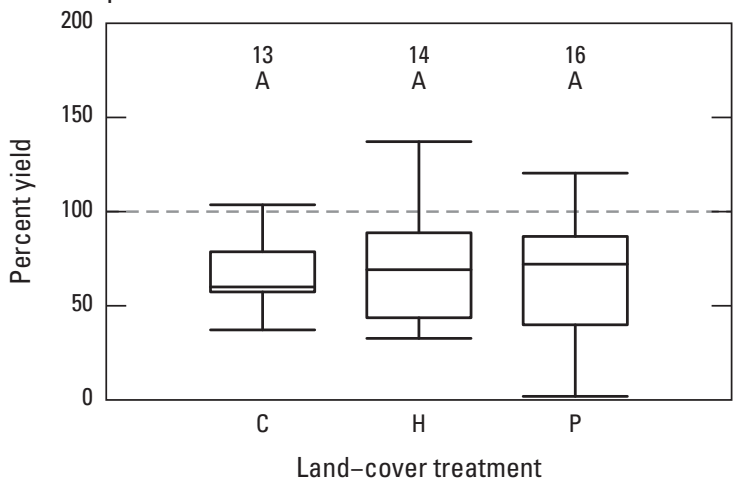

B. Sulfamethazine spike percent yield in soil extracts

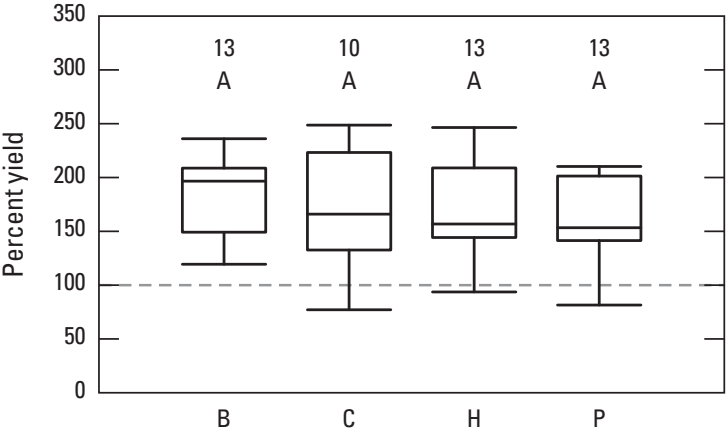

D. Sulfamethoxazole spike percent yield in soil extracts

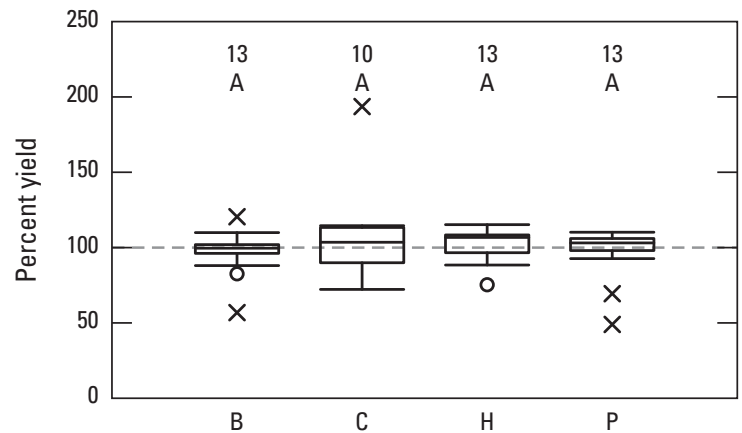

F. 17-beta-estradiol spike percent yield in soil extracts

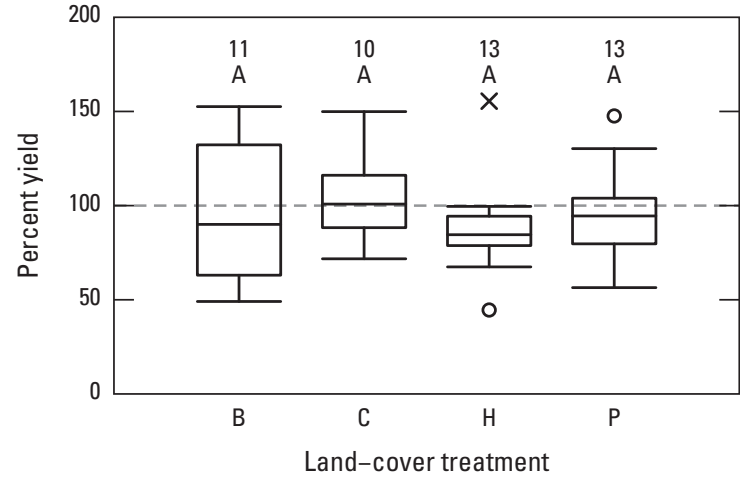

EXPLANATION

$\begin{array}{cl} & \text { Abbreviations } \\ \text { B } & \text { Samples from bare soil plots } \\ \text { C } & \text { Samples from corn plots } \\ \text { H } & \text { Samples from hay plots } \\ \text { P } & \text { Samples from prairie plots } \\ & \text { Number of values } \\ \text { A } & \begin{array}{l}\text { Significantly different groups as } \\ \text { indicated by a nonparametric } \\ \text { Tukey Honest Significant } \\ \text { Difference test ( } \boldsymbol{p} \text {-value less } \\ \text { than 0.10) }\end{array}\end{array}$

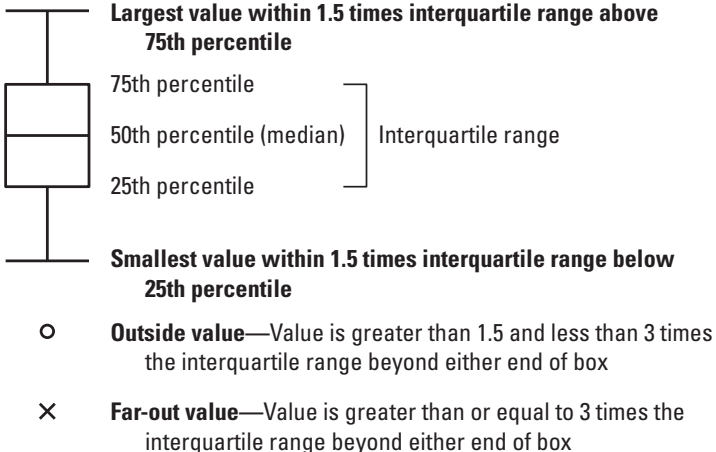

Figure 6. Boxplots of spike percent yield (recovery) in plant-tissue and soil extracts, spiked before extraction. $A$, sulfamethazine (SMZ) in plant-tissue extracts; $B, S M Z$ in soil extracts; $C$, sulfamethoxazole (SMX) in plant-tissue extracts; $D$, SMX in soil extracts; $E$, 17-beta-estradiol (17BE) in plant-tissue extracts; and $F$, 17BE in soil extracts. 
Table 8. Summary of Kruskal-Wallis rank sum test results for plant-tissue, soil, and root samples collected in 2009 at Cedar Creek Ecoystem Science Reserve, Minnesota.

[Experimental group descriptions, treatment equals plots amended with sulfamethazine (SMZ), sulfamethoxazole (SMX), and 17-beta-estradiol (17BE), and control equals plots not amended with SMZ, SMX, and 17BE: B equals combined treatment and control bare soil plots; C equals combined treatment and control corn plots; H equals combined treatment and control hay plots; P equals combined treatment and control prairie plots. BT, CT, HT, PT equals bare soil, corn, hay, and prairie treatment plots; BC, CC, HC, PC equals bare soil ,corn, hay, and prairie control plots; Ctrl equals pooled B, C, H, P control plots; Trt equals pooled B, C, H, P treatment plots. Significance level codes: NS, not significant, $p$-value equal to or greater than 0.10 ; *, marginally significant, $p$-value between 0.05 and $0.10 ; * *$, significant, $p$-value less than $0.05 . \mathrm{cm}$, centimeters; --, value not determined; <, less than]

\begin{tabular}{|c|c|c|c|c|c|c|c|}
\hline Response variable & $\begin{array}{l}\text { Sampling } \\
\text { period }\end{array}$ & $\begin{array}{l}\text { Experimental } \\
\text { groups compared }\end{array}$ & Chemical & $\begin{array}{l}\text { Chi-squared } \\
\text { test statistic }\end{array}$ & $\begin{array}{l}\text { Degrees of } \\
\text { freedom }\end{array}$ & $p$-value & $\begin{array}{l}\text { Significance } \\
\text { level }\end{array}$ \\
\hline \multirow{3}{*}{$\begin{array}{l}\text { Spike percent yield in } \\
\text { plant-tissue extract } \\
\text { samples }\end{array}$} & \multirow[t]{3}{*}{ April and June } & \multirow[t]{3}{*}{$\mathrm{C}, \mathrm{H}, \mathrm{P}$} & SMX & 0.97 & 2 & 0.62 & NS \\
\hline & & & SMZ & 4.29 & 2 & 0.12 & NS \\
\hline & & & $17 \mathrm{BE}$ & 0.18 & 2 & 0.92 & NS \\
\hline \multirow{3}{*}{$\begin{array}{l}\text { Spike percent yield in soil- } \\
\text { extract samples }\end{array}$} & \multirow[t]{3}{*}{ April and June } & \multirow[t]{3}{*}{$\mathrm{B}, \mathrm{C}, \mathrm{H}, \mathrm{P}$} & SMX & 2.42 & 3 & 0.49 & NS \\
\hline & & & SMZ & 1.06 & 3 & 0.79 & NS \\
\hline & & & $17 \mathrm{BE}$ & 4.08 & 3 & 0.25 & NS \\
\hline \multirow{6}{*}{$\begin{array}{l}\text { Areal concentration in } \\
\text { plant tissues }\end{array}$} & \multirow[t]{3}{*}{ June } & \multirow{3}{*}{$\begin{array}{l}\text { CC, CT, HC, HT, } \\
\text { PC, PT }\end{array}$} & SMX & 17.91 & 5 & 0.003 & $* *$ \\
\hline & & & SMZ & 17.77 & 5 & 0.003 & $* *$ \\
\hline & & & $17 \mathrm{BE}$ & 4.66 & 5 & 0.46 & NS \\
\hline & \multirow[t]{3}{*}{ August } & \multirow{3}{*}{$\begin{array}{l}\mathrm{CC}, \mathrm{CT}, \mathrm{HC}, \mathrm{HT} \\
\text { PC, PT }\end{array}$} & SMX & 11.95 & 5 & 0.04 & $* *$ \\
\hline & & & SMZ & 9.64 & 5 & 0.09 & $*$ \\
\hline & & & $17 \mathrm{BE}$ & 10.46 & 5 & 0.06 & $*$ \\
\hline \multirow{12}{*}{$\begin{array}{l}\text { Areal concentration in soil } \\
(0-10 \mathrm{~cm} \text { below land } \\
\text { surface })\end{array}$} & \multirow[t]{6}{*}{ April } & \multirow[t]{3}{*}{ Ctrl, Trt } & SMX & 4.06 & 1 & 0.04 & $* *$ \\
\hline & & & SMZ & 6.55 & 1 & 0.01 & $* *$ \\
\hline & & & $17 \mathrm{BE}$ & -- & -- & -- & NS \\
\hline & & \multirow{3}{*}{$\begin{array}{l}\text { BT, CT, HT, PT, } \\
\text { Ctrl }\end{array}$} & SMX & 8.12 & 4 & 0.09 & $*$ \\
\hline & & & SMZ & 12.22 & 4 & 0.02 & $* *$ \\
\hline & & & $17 \mathrm{BE}$ & -- & -- & -- & NS \\
\hline & \multirow[t]{6}{*}{ June } & \multirow[t]{3}{*}{ Ctrl, Trt } & SMX & 4.54 & 1 & 0.03 & $* *$ \\
\hline & & & SMZ & 6.23 & 1 & 0.01 & $* *$ \\
\hline & & & $17 \mathrm{BE}$ & 0.32 & 1 & 0.57 & NS \\
\hline & & \multirow{3}{*}{$\begin{array}{l}\text { BT, CT, HT, PT, } \\
\text { Ctrl }\end{array}$} & SMX & 8.31 & 4 & 0.08 & $*$ \\
\hline & & & SMZ & 13.67 & 4 & 0.008 & $* *$ \\
\hline & & & $17 \mathrm{BE}$ & 4.00 & 4 & 0.41 & NS \\
\hline $\begin{array}{l}\text { Soil } \mathrm{pH}(0-10 \mathrm{~cm} \text { below } \\
\text { land surface) }\end{array}$ & April and June & $\mathrm{B}, \mathrm{C}, \mathrm{H}, \mathrm{P}$ & -- & 5.79 & 3 & 0.12 & NS \\
\hline $\begin{array}{l}\text { Gravimetric soil-water } \\
\text { content }(0-10 \mathrm{~cm} \text { below } \\
\text { land surface })\end{array}$ & April and June & $\mathrm{B}, \mathrm{C}, \mathrm{H}, \mathrm{P}$ & -- & 6.15 & 3 & 0.10 & NS \\
\hline $\begin{array}{l}\text { Hours between spray appli- } \\
\text { cation and soil sampling }\end{array}$ & April & $\mathrm{B}, \mathrm{C}, \mathrm{H}, \mathrm{P}$ & -- & 2.14 & 3 & 0.54 & NS \\
\hline $\begin{array}{l}\text { Root biomass to } 30 \mathrm{~cm} \\
\text { below land surface }\end{array}$ & July & $\mathrm{B}, \mathrm{C}, \mathrm{H}, \mathrm{P}$ & -- & 22.28 & 3 & $<0.0001$ & $* *$ \\
\hline \multirow{2}{*}{$\begin{array}{l}\text { Aboveground biomass, } \\
\text { fresh }\end{array}$} & June & $\mathrm{B}, \mathrm{C}, \mathrm{H}, \mathrm{P}$ & -- & 21.41 & 3 & $<0.0001$ & $* *$ \\
\hline & August & $\mathrm{B}, \mathrm{C}, \mathrm{H}, \mathrm{P}$ & -- & 21.38 & 2 & $<0.0001$ & $* *$ \\
\hline
\end{tabular}


Table 9. Quality-assurance summary for bromide concentrations and water-quality characteristics in water samples analyzed at the U.S. Geological Survey National Water Quality Laboratory.

$\left[n\right.$, number of samples; $\mathrm{mg} / \mathrm{L}$, milligrams per liter; $<$, less than; $\mu \mathrm{S} / \mathrm{cm}$ at $25{ }^{\circ} \mathrm{C}$, microsiemens per centimeter at 25 degrees Celsius; ${ }^{\circ} \mathrm{C}$, degrees $\mathrm{Celsius;} \mathrm{--,} \mathrm{data}$ not presented]

\begin{tabular}{llccc}
\hline \multicolumn{1}{c}{ Chemical or property } & \multicolumn{1}{c}{ Units } & $\begin{array}{c}\text { Sample at site 452408093111701 } \\
\text { (well CC238 in plot 269) on } \\
\text { November 19, 2008, at 10:00 a.m. }\end{array}$ & $\begin{array}{c}\text { Relative percent } \\
\text { difference of sequential } \\
\text { replicate sample }\end{array}$ & $\begin{array}{c}\text { Range of concentrations in } \\
\text { field blank samples ( } \mathbf{n = 2 1 )}\end{array}$ \\
\hline Bromide & $\mathrm{mg} / \mathrm{L}$ & 0.01 (estimated) & 0 & not detected, all <0.02 \\
$\mathrm{pH}$ (onsite) & $\mathrm{pH}$ units & 8 & 2.5 & - \\
Specific conductance (onsite) & $\mu \mathrm{S} / \mathrm{cm}$ at $25^{\circ} \mathrm{C}$ & 63 & 6.6 & - \\
Water temperature (onsite) & ${ }^{\circ} \mathrm{C}$ & 9.9 & 4 \\
\hline
\end{tabular}

\section{Sulfamethazine and Sulfamethoxazole}

Kruskal-Wallis rank sum tests indicate that areal concentrations of SMZ and SMX in the upper $10 \mathrm{~cm}$ of soil $\left(\left[x_{A, s o}\right]\right)$ were significantly greater in treatment plots compared to control plots during the April 2009 and June 2009 sampling periods (figs. $7 A-D$; table 8). These data indicate that SMZ and SMX successfully reached the soil of treatment plots through the spray application procedure and that these chemicals persisted in the upper $10 \mathrm{~cm}$ of soil for at least 8 weeks. Variability in the measured areal concentrations of SMZ and SMX was substantial in the soil immediately following the April 2009 application. Areal concentrations in the treatment plots ranged from 0 to $26.8 \mathrm{mg} / \mathrm{m}^{2}$ for SMZ and from 1.1 to $14.6 \mathrm{mg} / \mathrm{m}^{2}$ for SMX (table 4-1 in appendix 4). The application rate for these chemicals was $5.6 \mathrm{mg} / \mathrm{m}^{2}$ in 2008 and $11.2 \mathrm{mg} / \mathrm{m}^{2}$ in 2009 .

Some of the variability in the areal concentrations of SMZ in soil can be explained by the land-cover treatments (fig. 8A). Areal concentrations of SMZ in the upper $10 \mathrm{~cm}$ of soil tended to be highest in the prairie plots in April 2009 (fig. 8A). A Kruskal-Wallis rank sum test of the April SMZ data indicated a significant difference ( $p$-value $=0.02$, table 8 ) among land-cover treatments. The only significant pairwise difference was between the pooled control plots and prairie treatment plots. A Kruskal-Wallis rank sum test was still significant ( $p$-value $=0.008$ ) for the June 2009 data, but the only significant pairwise difference was between the corn treatment plots and the control plots (fig. $8 B$; table 8 ).

Patterns in the areal concentrations of SMX in the upper $10 \mathrm{~cm}$ of soil were similar to the patterns observed in the SMZ data, but statistical tests of the SMX data revealed weaker differences among experimental groups than those observed for SMZ (table 8; figs. $8 A-D$ ). Areal concentrations of SMX in the upper $10 \mathrm{~cm}$ of soil tended to be highest in the prairie plots in April 2009. A Kruskal-Wallis rank sum test on the April 2009 SMX data indicated a marginally significant difference ( $p$-value $=0.09$, table 8$)$ among land-cover treatments; the largest pairwise difference was between the pooled control plots and prairie treatment plots (fig. 8C). In June 2009, corn plots tended to have the highest areal concentrations of SMX in the upper $10 \mathrm{~cm}$ of soil (fig. $8 D$ ). A Kruskal-Wallis rank sum test on the June 2009 SMX data indicated a marginally significant difference ( $p$-value $=0.08$, table 8$)$ among land-cover treatments; the largest pairwise difference was between the pooled control plots and corn treatment plots (fig. $8 D$ ).

Areal concentrations of SMZ and SMX decreased from April 2009 to June 2009 most consistently in the prairie plots compared to all other treatments (figs. $9 A, B$ ). The areal concentration of SMZ decreased in all five prairie treatment plots and the decrease was marginally significant as indicated by a Wilcoxon signed rank test $(p$-value $=0.06$, fig. $9 A$ ). The areal SMX concentration decreased in the upper $10 \mathrm{~cm}$ of soil in 4 of 5 prairie plots, but the decrease was not statistically significant (fig. 9B). Areal concentrations of SMZ and SMX did not change substantially between April 2009 and June 2009 in any of the other treatments. Wilcoxon signed rank tests indicated no significant change in areal concentration for SMZ or SMX in bare soil, corn, hay, or control plots ( $p$-values $>0.15$ ).

Prairie plots tended to have the highest areal concentrations of SMZ and SMX in the upper $10 \mathrm{~cm}$ of soil immediately following application (figs. $8 \mathrm{~A}, \mathrm{C}$ ). Ancillary data collected with the soil samples include soil $\mathrm{pH}$ and gravimetric soilwater content, neither of which were significantly correlated with the areal concentrations of SMZ or SMX (Kendall's tau $p$-values all $>0.3$ ). The April 2009 soil samples were collected within 0.5 to 8 hours of application. But this variation in the length of time between spray application and sampling was not correlated negatively with the areal concentrations of SMZ and SMX in soil (Kendall's tau $p$-values all $>0.19$ ). Furthermore, none of these physical factors (soil pH, soil-water content, and length of time between application and sampling) were significantly different among the treatments (KruskalWallis $p$-values all greater than or equal to 0.10 , table 8 ).

In contrast to the results for physical factors described previously, belowground (roots) and aboveground plant biomass differed significantly between land-cover treatments 

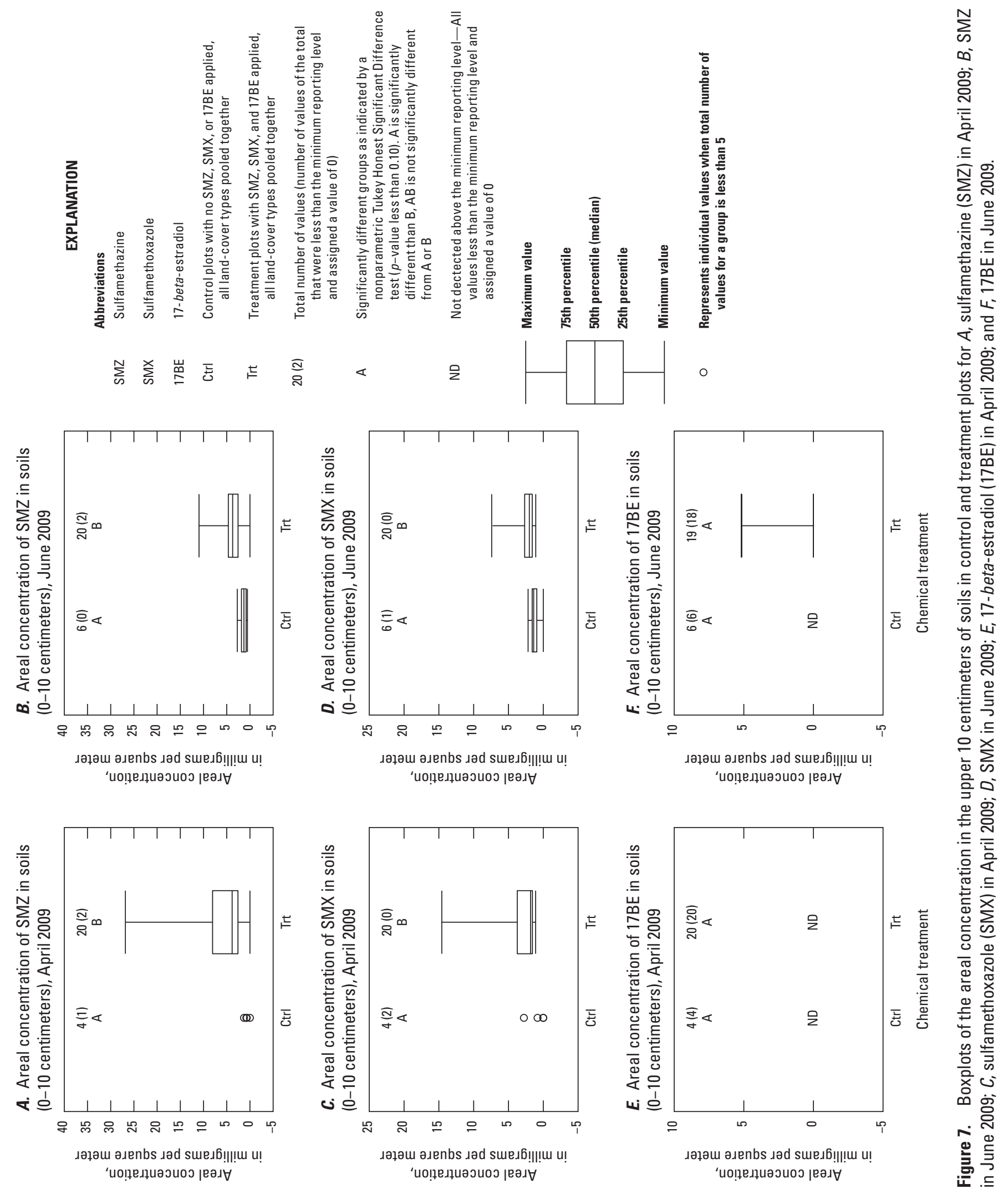

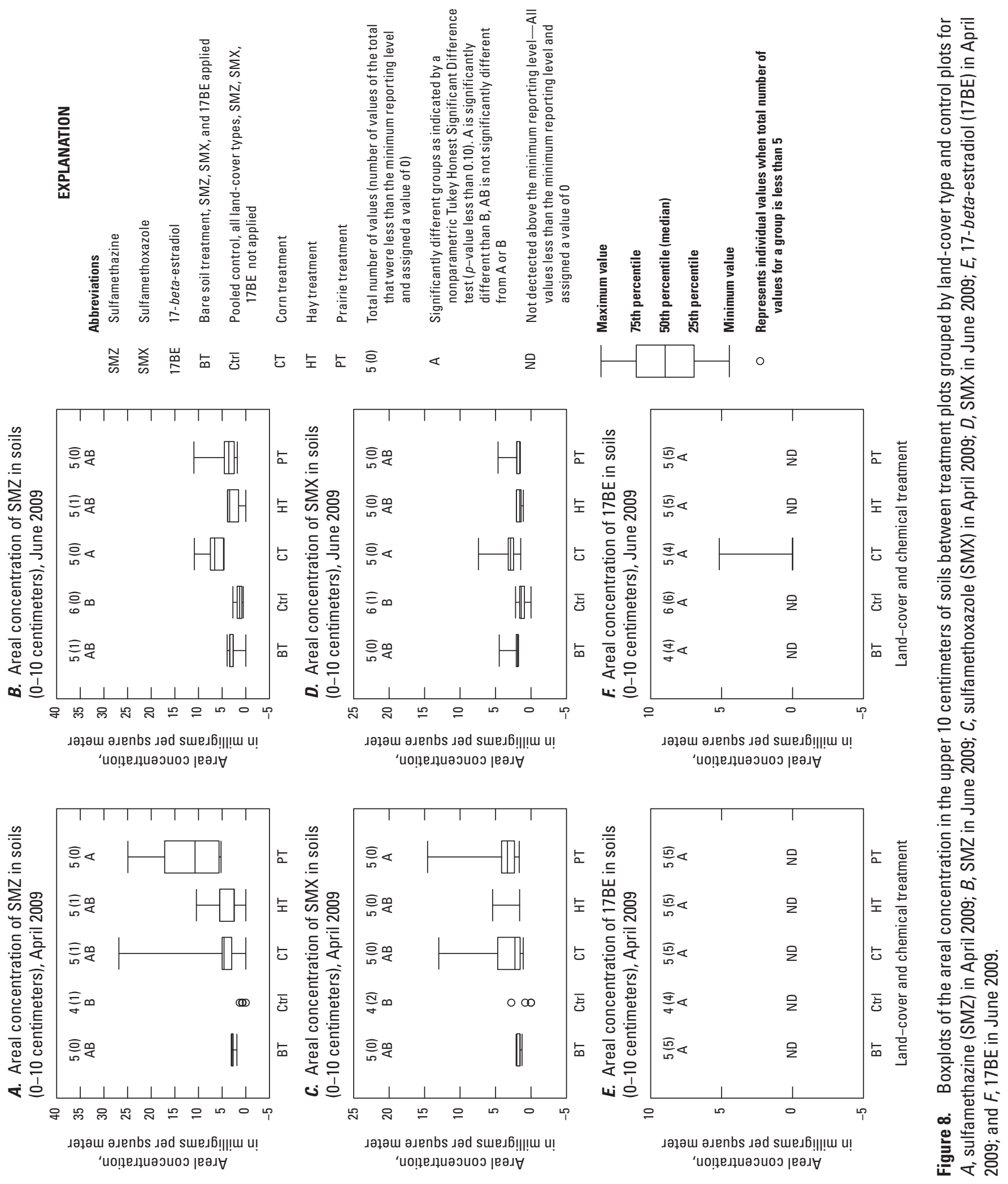


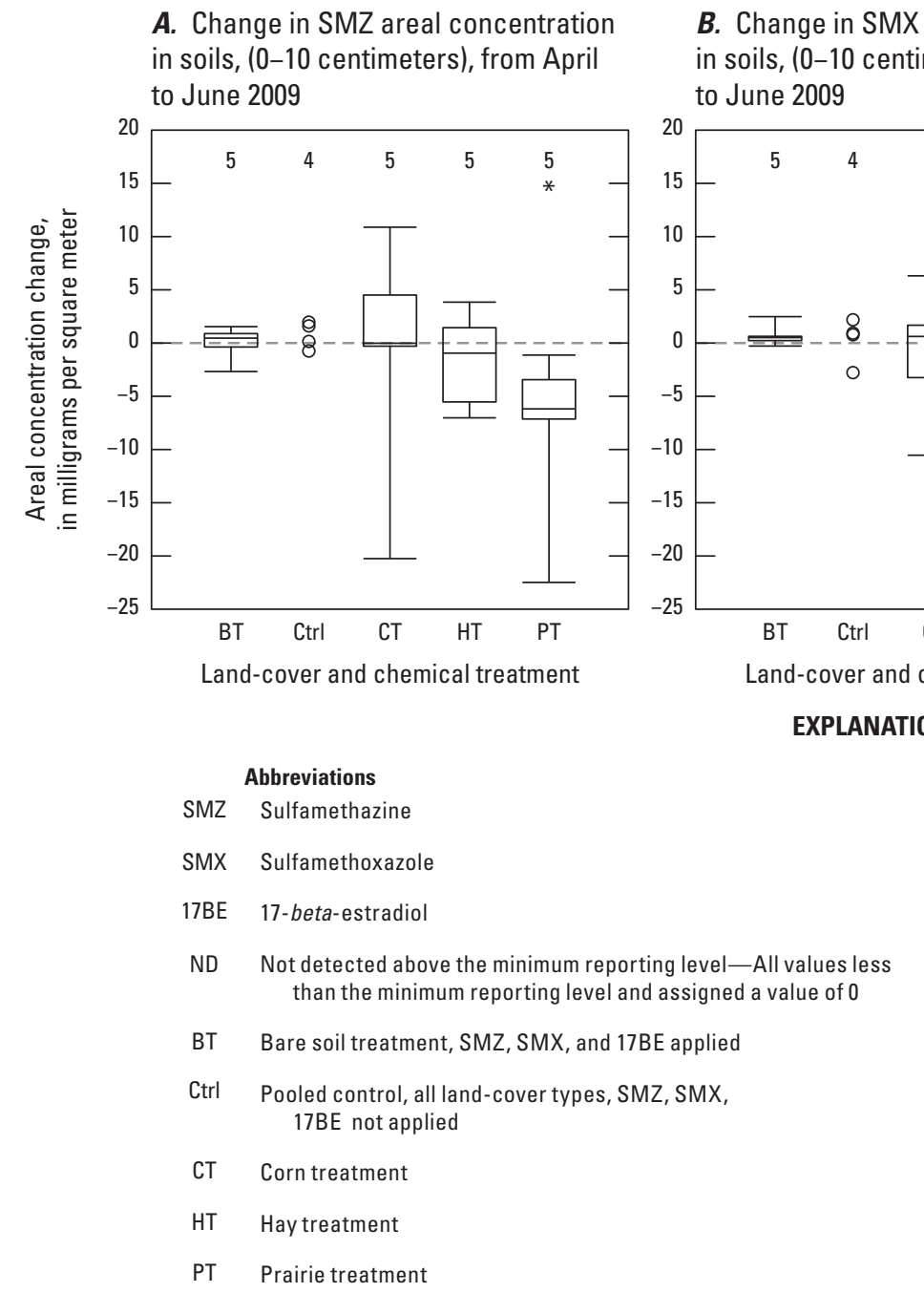

B. Change in SMX areal concentration in soils, (0-10 centimeters), from April to June 2009

Land-cover and chemical treatment
C. Change in $17 \mathrm{BE}$ areal concentration in soils, (0-10 centimeters), from April to June 2009

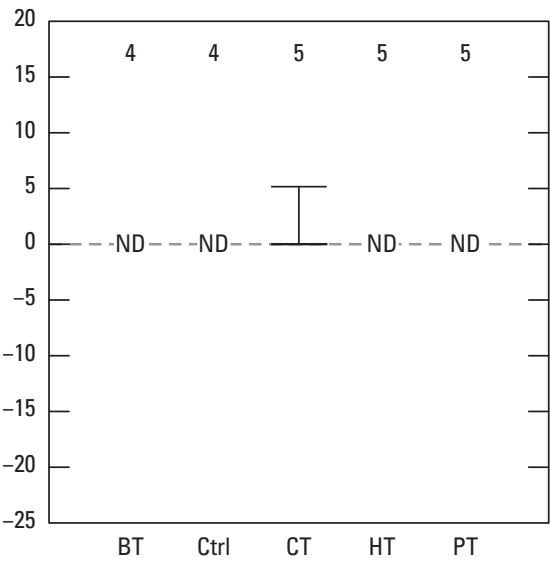

Land-cover and chemical treatment

Figure 9. Boxplots of the change in areal concentration in the upper 10 centimeters of soils between April 2009 and June 2009 for $A$, sulfamethazine; $B$, sulfamethoxazole; and $C$, 17-beta-estradiol.

(figs. $10 A-C$; table 8). Prairie plots had significantly more root biomass than corn and bare soil plots in the upper $30 \mathrm{~cm}$ of the soil profile in July 2009 (Kruskal-Wallis rank sum test $p$-value $<0.0001$, fig. $10 C$; table 8 ). Although not statistically significant, prairie plots also tended to have greater root biomass than hay plots (fig. 10C).

The high root biomass in prairie plots may have resulted in soil samples that were more representative of the entire $0-10$-cm soil profile compared to soil samples collected from plots of the other land-cover types. The root mass in the upper $10 \mathrm{~cm}$ of prairie soil stabilized the uppermost part of the soil sample during sample processing. It was observed during soil core processing that, in soil samples with little root biomass, the top and bottom ends of the soil samples tended to slough off. This is of particular importance for the April 2009 soil sampling because most of the application solution probably was within the upper $1 \mathrm{~cm}$ of the soil sample. The volume of solution applied, $133 \mathrm{~L}$, was equivalent to a distributed depth of only $0.11 \mathrm{~cm}$ over a plot. If, for example, any of the upper
$0.5 \mathrm{~cm}$ of the soil sample sloughed away and was underrepresented in the final subsample used for chemical analyses, a substantial underestimation of the areal concentration would result. Also, the presence of a well-established root network close to the prairie soil surface may have increased the depth and infiltration rate of the application solution in prairie plots compared to the other plots. Perennial grasses have been determined to increase infiltration substantially compared to row-crop agriculture (Rachman and others, 2004; Wuest and others, 2006; Schilling and others, 2008).

The corn plots tended to have the highest measured areal concentrations of SMZ and SMX in soil in June 2009 (figs. $8 B, D$ ). The issue of "representativeness" of the soil samples collected in these plots again became important. The corn plots, but no other treatment plots, were roto-tilled between April 2009 and June 2009. Roto-tilling mixed the upper $10 \mathrm{~cm}$ of soil, and distributed the soil to which SMZ and SMX were applied directly more evenly throughout the upper $10 \mathrm{~cm}$ of soil. This mixing made the soil samples from corn plots much 

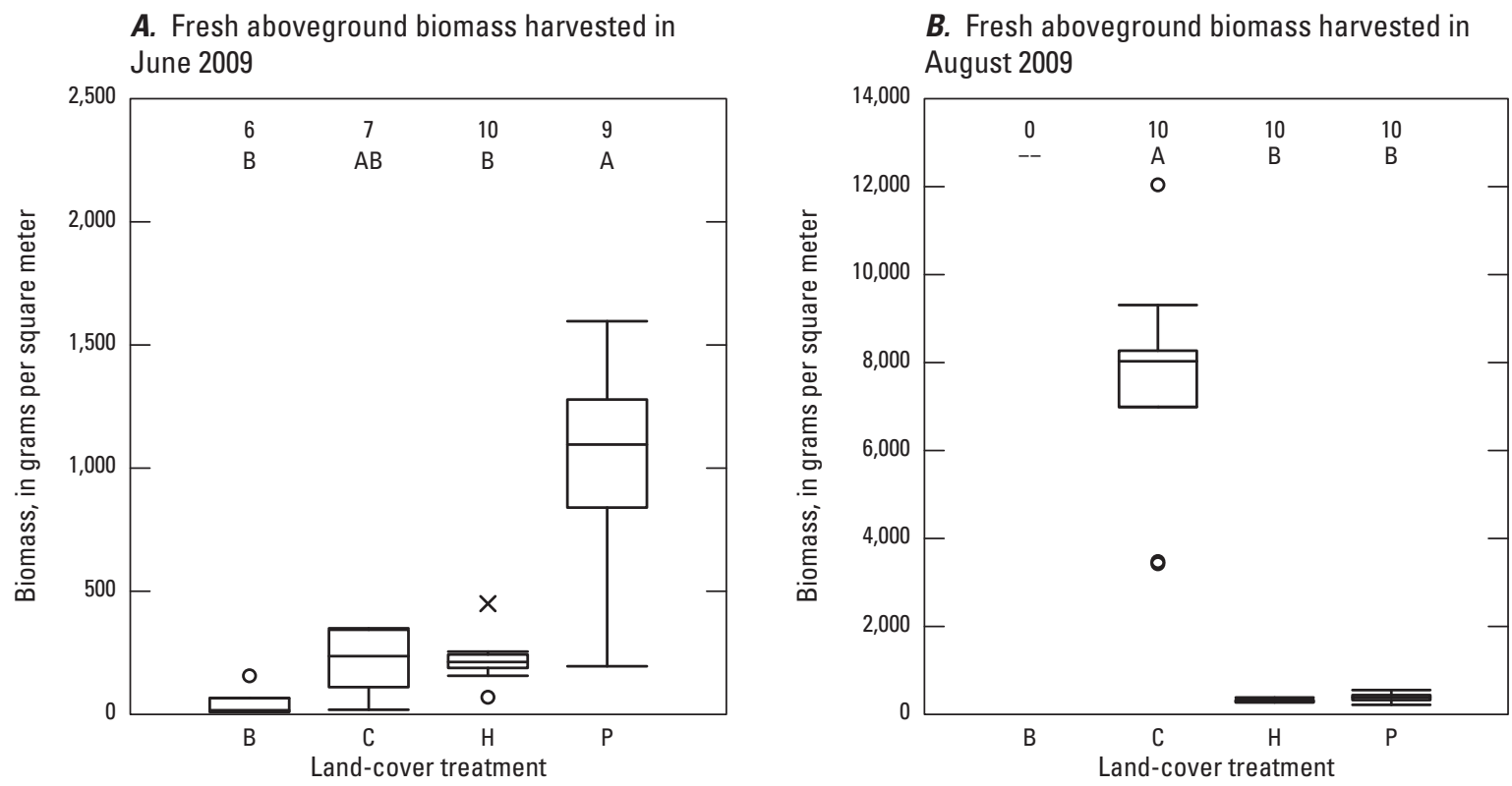

C. Root biomass in upper 30 centimeters of soil, July 2009
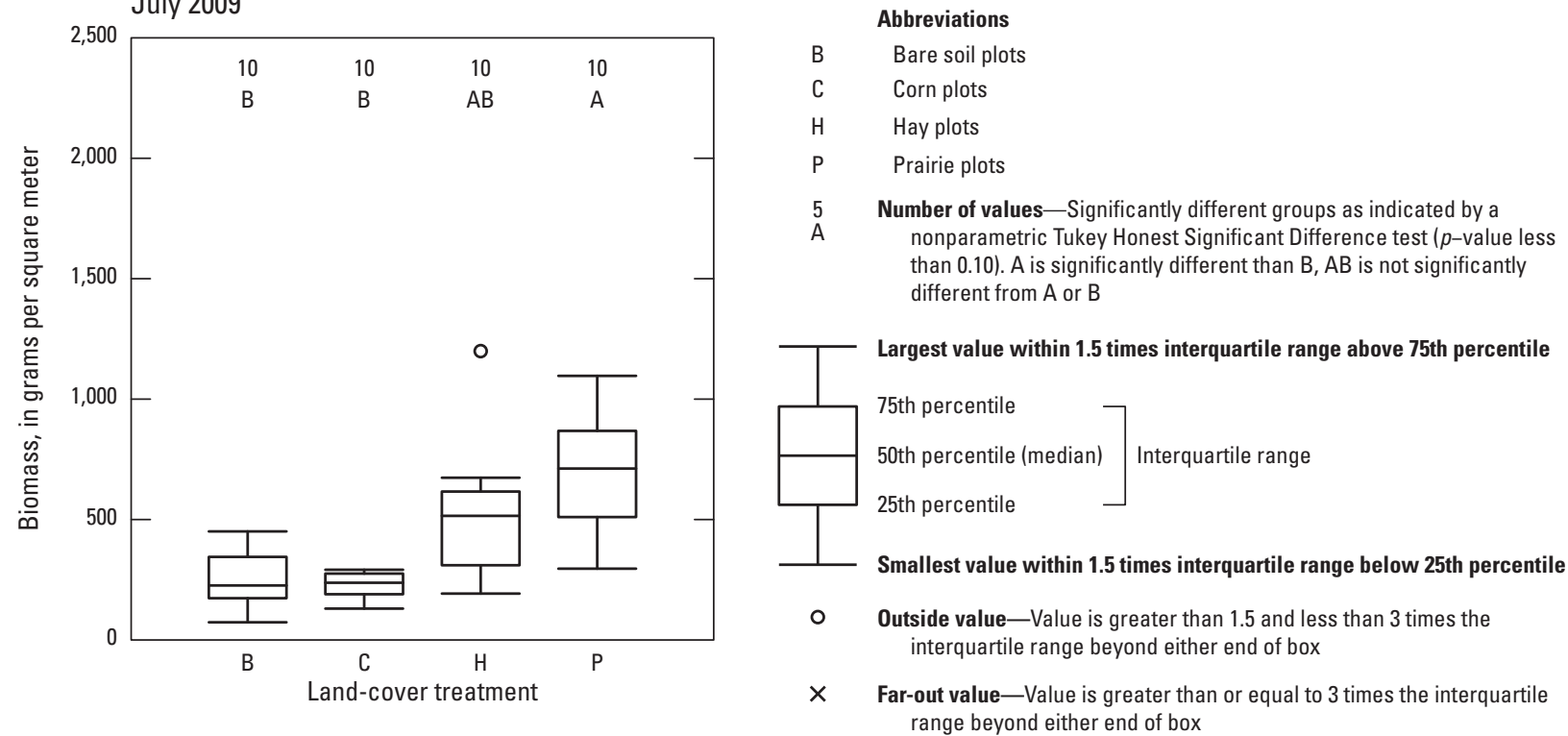

Figure 10. Boxplots of fresh aboveground biomass harvested from research plots in $A$, June 2009; $B$, August 2009; and $C$, dry root biomass harvested from the upper 30 centimeters of soil in July 2009.

less sensitive to top-of-core sloughing losses compared to soil samples from bare soil and hay land-cover types.

This issue of "representativeness" is one explanation for the low initial SMZ and SMX soil concentrations in most nonprairie treatment plots. Because of the likelihood that the initial concentrations of SMZ and SMX were underestimated in nonprairie plots, it is also likely that the within-plot changes from April 2009 to June 2009 in bare soil, corn, and hay plots were underestimated (figs. 9A,B).

Possible reasons for the decrease in areal concentrations of SMZ and SMX in the soil of prairie plots are numerous, and two potential pathways for SMZ and SMX loss from soil were explored further in this experiment: (1) plant uptake and (2) leaching losses below the rooting zone. Degradation of the surface-applied SMZ, SMX, and 17BE by soil microbes, sunlight, or other processes, also likely affected the fate and transport of these chemicals during the experiment (Boxall and others, 2004), but were not examined.

Areal concentrations of SMZ and SMX in prairie plant tissue did not explain the temporal changes in areal concentrations in soil of these chemicals. The areal concentrations of SMZ and SMX in the aboveground plant tissues in June 2009 and August 2009 were much lower, generally two to three orders of magnitude, than the areal concentrations of these 
chemicals in soil (figs. $8 A-D$; figs. $11 A-D$; figs. $12 A, B$ ). Pooling all treatment plot data for all sampling events, the median areal concentration of SMZ and SMX in plant tissues was 0.01 and 0.10 percent of the applied mass compared to 22 and 12 percent in soil, respectively (figs. 12A,B).

Areal concentrations of SMZ and SMX in plant-tissue samples were variable, and did not differ significantly between control and treatment plots within each land-cover type (table 8; figs. 11A-D). The lack of separation between plant-tissue samples from control and treatment plots for SMZ and SMX likely was caused by one or more of the following: the chemicals were not present in sufficient quantities to be detected above background matrix interferences, the chemicals were present but in a form for which ELISA kits were less sensitive, or the chemicals were present in plant tissues but not extracted from the plant-tissue matrix efficiently.

Contamination across the entire experimental field was not a likely cause because no outside sources of SMZ and SMX (beyond that which was applied as part of the experiment) were identified. The experimental field had not been managed for the production of row crops since 1967, and the upper 6 to $8 \mathrm{~cm}$ of soil that had been under row-crop management was removed from the field in 1993 (Cedar Creek Ecosystem Science Reserve, 2012a). No wastewater-treatment facilities or large animal feeding operations were within $10 \mathrm{~km}$ of the site during the experiment. The only septic system hydraulically upgradient was approximately $0.5 \mathrm{~km}$ away and served a single-family dwelling that was unoccupied for at least 10 months each year. It is not likely that the similarity between control and treatment plots was caused by sample contamination because SMZ and SMX detections in blanks were rare (figs. $4 A, B$; table 5). Spike recoveries of these chemicals were reasonable (figs. $6 A, B$ ) indicating that, if either chemical were present in sufficient quantities, it would have been detected.

The antibiotics SMZ and SMX also can be transported through the soil profile by way of advective transport as water percolates from land surface to groundwater. Several studies have documented that SMZ and SMX are mobile in soil water and groundwater (Hamscher and others, 2005; Miller and Meek, 2006; Kemper, 2008). In particular, a study of sandy soils demonstrated a persistent presence of SMZ in soil water $140 \mathrm{~cm}$ below land surface despite low SMZ concentrations in the upper $10 \mathrm{~cm}$ of the soil profile and undetectable SMZ from 10 to $90 \mathrm{~cm}$ of the soil profile (Hamscher and others, 2005).

The chemical SMZ leached below the rooting zone of all four land-cover types; it was detected in at least one soil-water or groundwater sample from each land-cover type (table 10). SMZ was detected in 23 percent of soil-water samples and in 16 percent of groundwater samples collected from treatment plots (table 10, table 4-1 in appendix 4). SMZ was detected most frequently in soil water beneath hay plots, followed by bare soil plots, then prairie plots, and finally corn plots (table 10). The highest SMZ concentration, $320 \mathrm{ng} / \mathrm{L}$, was measured in the soil water from a hay plot. The antibiotic SMZ was never detected in soil water below any corn plot and in only one groundwater sample below a corn plot (table 10). These observed patterns in SMZ leaching through soil across land-cover types are different than the patterns of bromide leaching described in Trost (2010), where bromide leached much more readily through corn plots than it did through prairie and hay.

The chemical SMX was detected much less frequently than SMZ in soil-water and groundwater samples, indicating that SMX was transported more slowly through soil than SMZ. The antibiotic SMX was detected in only 1 percent of soil-water samples and never detected in groundwater samples from treatment plots (table 10). The SMX detections in soil water were all low concentration, each only $10 \mathrm{ng} / \mathrm{L}$ greater than the MRL for the kit on which the sample was run. Four SMX detections were recorded, all in soil-water samples from prairie plots; two samples were from treatment plots and two samples were from control plots. Three of the detections were in soil-water samples collected on October 31, 2008. Bromide that was applied with SMX in May 2008, was not detected in the soil-water samples from these plots on or before October 31, 2008. These observations provide little evidence that SMX is transported below the rooting zone more quickly in prairies compared to the other land-cover treatments. Furthermore, these rare, low-level detections of SMX in prairie plots contradict soil-water balance calculations and the overall bromide tracer results, which indicate that prairies retain solutes in the soil profile longer than the other land-cover treatments (Trost, 2010).

During the two growing seasons comprising this study, advective transport through soil to groundwater was a pathway by which surface-applied SMZ left the different land-cover types. The lack of SMX detections in soil-water and groundwater samples did not support a similar conclusion for SMX. The study by Hamscher and others (2005) indicated that SMZ, not SMX, was transported from land surface to $140 \mathrm{~cm}$ below land surface. In the present study, it is possible that SMX was present in the soil profile between 10 and $160 \mathrm{~cm}$ below land surface, because this zone was not sampled.

\section{7-beta-Estradiol}

In contrast to SMZ and SMX, 17BE was not reliably detected in soil samples. Of the 49 soil samples analyzed, 17BE was only detected in one soil sample from June 2009 (fig. $8 F$ ). This sample had an areal concentration that was much greater ( 860 percent) than the concentration applied to the plots and was excluded from figure $12 C$. The chemical 17BE was not detected in any soil samples collected from treatment plots immediately after application in April 2009, the same samples in which SMZ and SMX were detected. This low rate of detection likely was not caused by incompatibilities between the ELISA kits and the citric acid extract buffer because spike percent yields of 17BE in soil generally ranged from 75 to 125 percent (fig. $6 F$ ). The more likely explanation is that the concentration of $17 \mathrm{BE}$ in the soil-sample extracts 


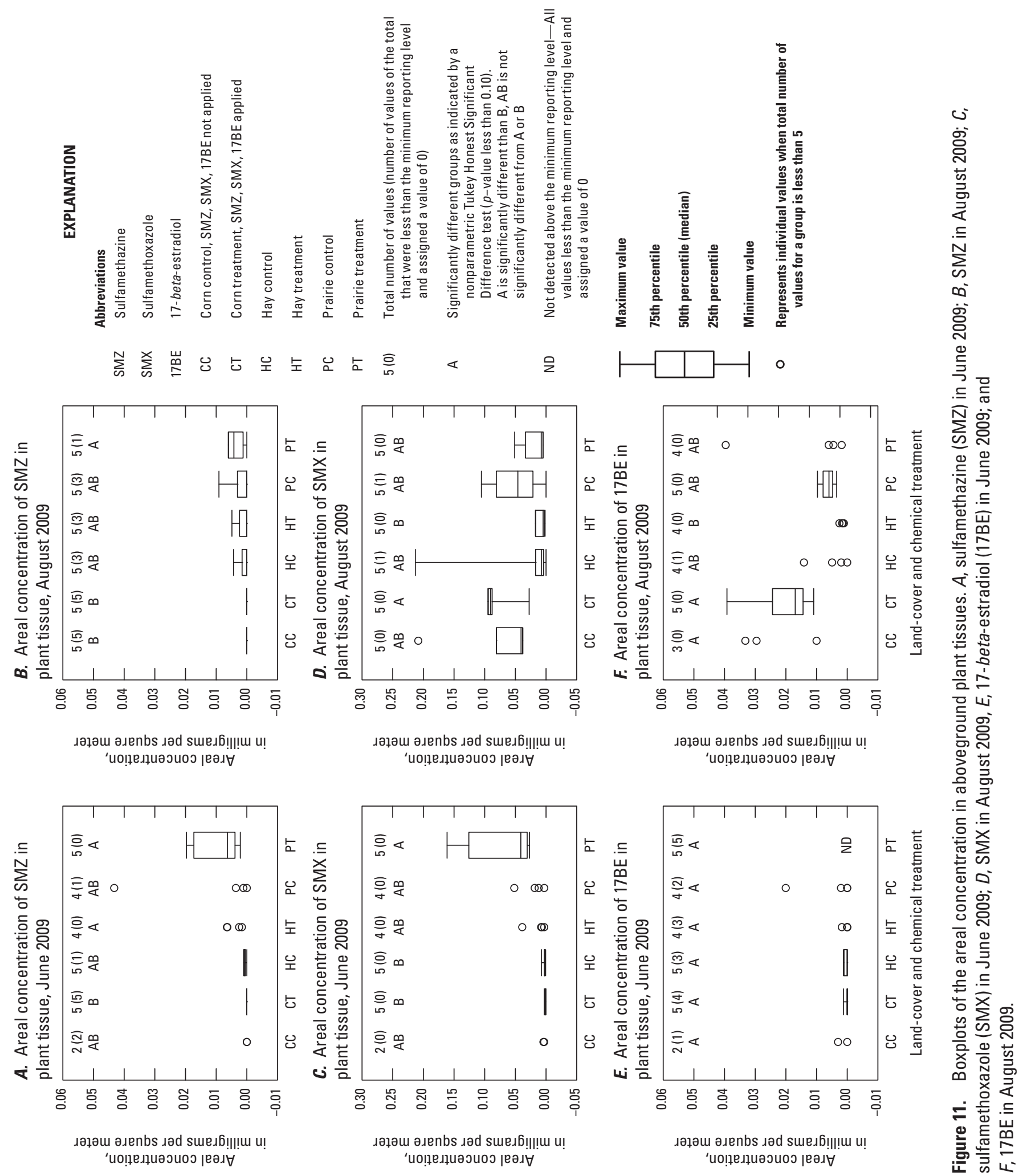


A. Percent of applied sulfamethazine in all planttissue and soil samples from treatment (T) plots

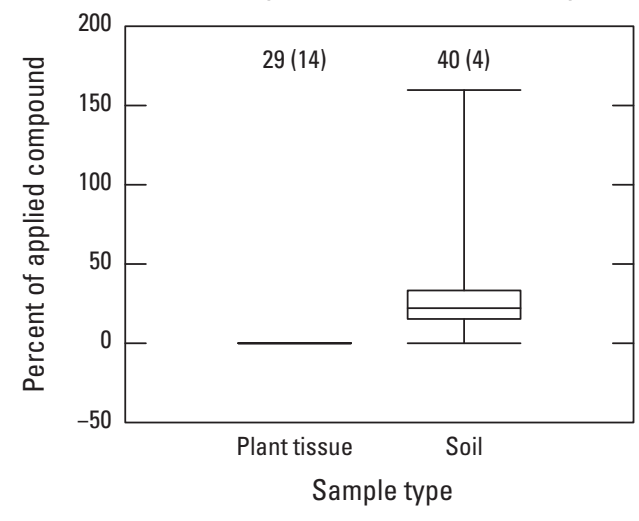

B. Percent of applied sulfamethoxazole in all planttissue and soil samples from treatment (T) plots

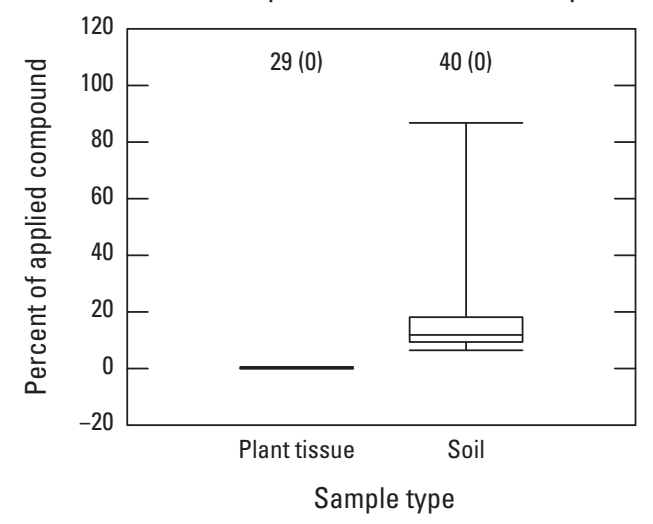

C. Percent of applied 17-beta-estradiol in all planttissue and soil samples from treatment (T) plots

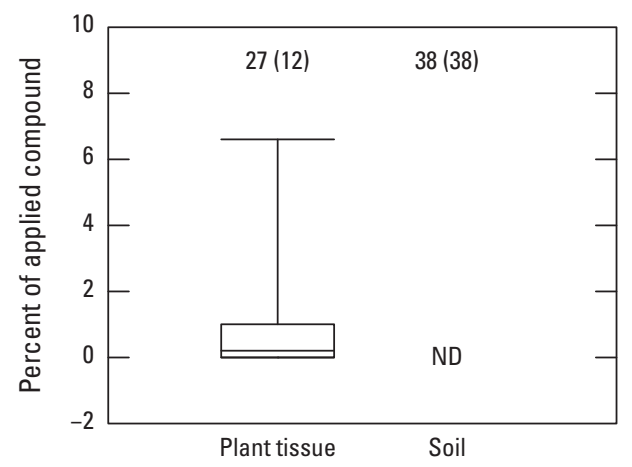

was too low to be detected by the 17BE kits because the soil-sample extracts were diluted 1:500 before 17BE ELISA analysis. Even if $17 \mathrm{BE}$ was present in the original soil sample, the 17BE kits, with a method detection limit of $2.5 \mathrm{ng} / \mathrm{L}$, were not sensitive enough to detect 17BE after the 1:500 dilution. In contrast, the soil-sample extracts analyzed for SMZ and SMX were only diluted 1:10 before ELISA analysis. The 1:500 dilution step was done before 17BE ELISA analysis to minimize the soil matrix interference with the kit performance.

Patterns of 17BE detections in plant-tissue, soil-water, and groundwater samples indicate that an external source of

\section{EXPLANATION}

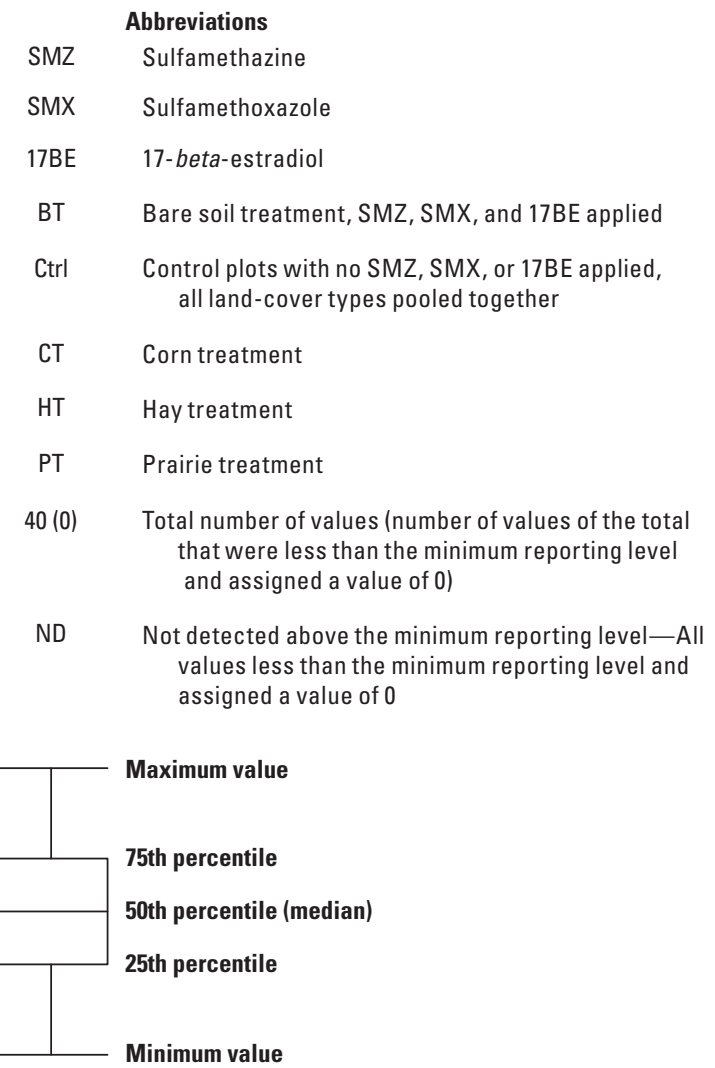

Figure 12. Boxplots of areal concentrations, as a percentage of the applied chemical, measured in treatment plots in the upper 10 centimeters of soil in April 2009 and June 2009 and in aboveground planttissue and soil samples in June 2009 and August 2009 for $A$, sulfamethazine (SMZ); $B$, sulfamethoxazole (SMX); and $C$, 17-beta-estradiol (17BE).

17BE, or other chemical for which the 17BE ELISA kits were sensitive, was present in the experimental field. The planttissue samples were diluted 1:500 before ELISA analysis, as were the soil samples, but 17BE was detected in nearly all of the plant-tissue samples. Given that SMZ and SMX concentrations in plant tissues were two to three orders of magnitude lower than concentrations in soil (figs. $8 A-D$; figs. $11 A-D$; figs. $12 A, B$ ), it is highly unlikely that the actual $17 \mathrm{BE}$ concentration in plant tissues would be at least two to three orders of magnitude greater than the concentration in soil. In soil-water and groundwater samples, the frequencies of detection and 
Table 10. Summary of detections of sulfamethazine (SMZ), sulfamethoxazole (SMX), and 17-beta-estradiol (17BE) in soil-water and groundwater samples collected from control and treatment plots of bare-soil, corn, hay, and prairie land-cover types.

[Control plots were not amended with SMZ, SMX, and 17BE; treatment plots were amended with SMZ, SMX, and 17BE; ng/L, nanograms per liter; ND, not detected above the minimum reporting level; NA, no samples analyzed]

\begin{tabular}{|c|c|c|c|c|c|c|}
\hline \multirow[b]{2}{*}{ Medium } & \multirow[b]{2}{*}{ Chemical } & \multirow[b]{2}{*}{$\begin{array}{c}\text { Land-cover } \\
\text { treatment }\end{array}$} & \multicolumn{2}{|c|}{ Control plots } & \multicolumn{2}{|c|}{ Treatment plots } \\
\hline & & & $\begin{array}{l}\text { Number of detections/ } \\
\text { number of samples } \\
\text { analyzed (frequency of } \\
\text { detection) }\end{array}$ & $\begin{array}{c}\text { Maximum } \\
\text { detected } \\
\text { concentration, } \\
\text { in ng/L }\end{array}$ & $\begin{array}{l}\text { Number of detections/ } \\
\text { number of samples } \\
\text { analyzed (frequency of } \\
\text { detection) }\end{array}$ & $\begin{array}{c}\text { Maximum } \\
\text { detected } \\
\text { concentration, } \\
\text { in ng/L }\end{array}$ \\
\hline \multirow[t]{12}{*}{ Soil-water } & \multirow{4}{*}{$\begin{array}{l}\text { Sulfamethazine } \\
\quad \text { (SMZ) }\end{array}$} & Bare soil (B) & $0 / 18(0.00)$ & ND & $6 / 25(0.24)$ & 220 \\
\hline & & Corn (C) & NA & NA & 0/19 (0) & ND \\
\hline & & Hay $(\mathrm{H})$ & $1 / 19(0.05)$ & 70 & $11 / 20(0.55)$ & 320 \\
\hline & & Prairie (P) & $0 / 9(0.00)$ & ND & $1 / 14(0.07)$ & 60 \\
\hline & \multirow{4}{*}{$\begin{array}{l}\text { Sulfamethoxazole } \\
\quad \text { (SMX) }\end{array}$} & Bare soil (B) & 0/19 (0.00) & ND & $0 / 26(0.00)$ & ND \\
\hline & & Corn $(\mathrm{C})$ & NA & NA & $0 / 21(0.00)$ & ND \\
\hline & & Hay $(\mathrm{H})$ & $0 / 19(0.00)$ & ND & $0 / 19(0.00)$ & ND \\
\hline & & Prairie $(\mathrm{P})$ & $2 / 9(0.22)$ & 80 & $2 / 15(0.13)$ & 40 \\
\hline & \multirow{4}{*}{$\begin{array}{l}\text { 17-beta-Estradiol } \\
\quad(17 \mathrm{BE})\end{array}$} & Bare soil (B) & $4 / 19(0.21)$ & 5.4 & $2 / 26(0.08)$ & 3.4 \\
\hline & & Corn $(\mathrm{C})$ & NA & NA & $5 / 20(0.25)$ & 6.3 \\
\hline & & Hay $(\mathrm{H})$ & 7/18 (0.39) & 7.5 & $8 / 20(0.40)$ & 7.4 \\
\hline & & Prairie $(\mathrm{P})$ & 4/9 (0.44) & 6.8 & 4/13 (0.31) & 5.6 \\
\hline \multirow[t]{12}{*}{ Groundwater } & \multirow{4}{*}{$\begin{array}{l}\text { Sulfamethazine } \\
\quad \text { (SMZ) }\end{array}$} & Bare soil (B) & $1 / 5(0.2)$ & 60 & $3 / 13(0.23)$ & 90 \\
\hline & & Corn $(\mathrm{C})$ & NA & NA & $1 / 14(0.07)$ & 110 \\
\hline & & Hay $(\mathrm{H})$ & $0 / 7(0.00)$ & ND & $2 / 10(0.20)$ & 50 \\
\hline & & Prairie $(\mathrm{P})$ & $0 / 4(0.00)$ & ND & $2 / 13(0.15)$ & 70 \\
\hline & \multirow{4}{*}{$\begin{array}{l}\text { Sulfamethoxazole } \\
\quad \text { (SMX) }\end{array}$} & Bare soil (B) & $0 / 5(0.00)$ & ND & $0 / 15(0.00)$ & ND \\
\hline & & Corn $(\mathrm{C})$ & NA & NA & $0 / 15(0.00)$ & ND \\
\hline & & Hay $(\mathrm{H})$ & $0 / 7(0.00)$ & ND & $0 / 10(0.00)$ & ND \\
\hline & & Prairie $(\mathrm{P})$ & $0 / 4(0.00)$ & ND & $0 / 15(0.00)$ & ND \\
\hline & \multirow{4}{*}{$\begin{array}{l}\text { 17-beta-Estradiol } \\
\quad(17 \mathrm{BE})\end{array}$} & Bare soil (B) & $0 / 5(0.00)$ & ND & $1 / 15(0.07)$ & 2.6 \\
\hline & & Corn $(\mathrm{C})$ & NA & NA & $1 / 15(0.07)$ & 3.1 \\
\hline & & Hay $(\mathrm{H})$ & $1 / 7(0.14)$ & 3.6 & $2 / 10(0.20)$ & 3.6 \\
\hline & & Prairie (P) & $0 / 4(0.00)$ & ND & $0 / 15(0.00)$ & ND \\
\hline
\end{tabular}

the maximum detected concentrations of $17 \mathrm{BE}$ were similar between control and treatment plots (table 10). This indicates that the experimental application of $17 \mathrm{BE}$ did not substantially increase the concentrations of $17 \mathrm{BE}$ in soil water and groundwater above "background" levels of 17BE or other chemical(s) that interfered with the 17BE ELISA kits.

The abundance of legumes, a source of phytoestrogens, in the experimental field may have made it difficult to quantify the 17BE applied as part of this experiment. Other research has demonstrated the presence of phytoestrogens in the environment (Erbs and others, 2007; Liu and others, 2010). These chemicals are bioactive secondary plant metabolites with structural and functional similarities to 17BE (Kuhnle and others, 2008), and legumes tend to have high concentrations of certain phytoestrogens (Price and Fenwick, 1985; Reinle and Block, 1996). A field study done in Switzerland documented phytoestrogens in drainage water leaving a pasture that was planted with 56 percent Italian ryegrass (Lolium multiflorum) and 43 percent red clover (Trifolium pratense) (Erbs and others, 2007). In the field in which the present experiment was done, several legumes were planted as part of the initial experimental establishment in 1994 (Cedar Creek Ecosystem 
Science Reserve, 2013a; Tilman, Reich, and Knops, 2006), and were well established from 2007 through 2009. Field observations indicated that the density of one legume species in particular, sundial lupine (Lupinus perennis), was much higher in the experimental field compared to the surrounding area. As described in the "Methods of Study" section in this report, one of the criteria for plot selection was that the plant cover in June 2007 consisted primarily (greater than 50 percent) of native $C_{4}$ (Raven and others, 1999) grasses and leguminous forbs (legumes). That means that all plots used for this experiment had legumes growing in them for several years before 2007. The Sigma Aldrich company states that their 17BE, which was applied in this study, was "derived from a plant source" (Sigma Aldrich, 1997, p. 1), which further indicates that $17 \mathrm{BE}$ or similar chemicals are present in plant tissues. The 17BE kit user's manual did not list any specific cross-reactivity problems for phytoestrogens (Abraxis, 2010a), so it is possible that the kits are sensitive to phytoestrogens, causing false positive results.

\section{Soil Hydrology and Chemical Properties}

The amount of water percolating through soil to groundwater (groundwater recharge) is an important factor that will affect the transport of SMZ, SMX, and 17BE. Differences in evapotranspiration (ET) and groundwater recharge between perennial and annual land-cover types have been observed in previous studies (Brye and others, 2000; Bekele and others, 2006). If the land-cover types of bare soil, corn, hay, and prairie differentially affect soil-water movement through soils then solutes may also be transported differently through soil. Because the soil-water and groundwater results for SMZ, SMX, and 17BE were variable amongst land-cover types, the results from a detailed soil hydrology investigation done in the same research plots are presented. A soil-water balance, water-table hydrograph analysis, and chemical analysis of a bromide tracer in the pore water of unsaturated soils and shallow groundwater were used to identify differences in rates and amounts of water and solute movement through soils underlying perennial and annual land-cover types (Trost, 2010).

Prairie and hay, which are perennial land-cover types, used water from the soil profile differently than annual corn during the growing season. In 2008 and 2009, the upper $125 \mathrm{~cm}$ of prairie soil profiles were significantly drier by midJuly than corn soil profiles because of greater early growing season ET demands by the perennial crops (Trost, 2010). Prairie ET rates peaked in mid-June, whereas ET rates peaked in August for corn (Trost, 2010). Despite the differences in the seasonal patterns of water use between the perennial land-cover types and annual corn, the cumulative total ET and percolation below the rooting zone between June 2008 and December 2009 were similar. The experimental field received a total of $107.2 \mathrm{~cm}$ of precipitation between June 2008 and December 2009. The cumulative ET estimates for hay, prairie, and corn were $71.6 \mathrm{~cm}, 73.9 \mathrm{~cm}$, and $69.1 \mathrm{~cm}$, respectively.
The cumulative percolation estimates for hay, prairie, and corn were $31.6 \mathrm{~cm}, 37.9 \mathrm{~cm}$, and $40.2 \mathrm{~cm}$, respectively (Trost, 2010).

The similarity in the cumulative percolation below the rooting zone and ET totals between annual and perennial land-cover types contrasts with several other studies that have documented large differences in these characteristics (Brye and others, 2000; Bekele and others, 2006). This contradiction can be explained at least in part by the annual harvesting of perennial biomass for the present study. The senesced plant material from the growth of previous years, or litter layer, of a perennial prairie intercepts substantial amounts of water, effectively reducing the volume of water that actually reaches the soil surface and infiltrates. Removal of a Kansas prairie's litter layer by burning increased precipitation throughfall (water reaching the soil surface) by 18 percent (Seastedt, 1985). A study in southern Wisconsin indicated that, of $68.1 \mathrm{~cm}$ of precipitation, $47.7 \mathrm{~cm}$ were intercepted by the litter layer and evaporated (Brye and others, 2000). Because the litter layer was harvested annually for the present study, a greater percentage of the precipitation infiltrated into the prairie soil profile than in either the Seastedt (1985) study or the Brye and others (2000) study.

The seasonal pattern in water use correlates with the seasonal pattern of biomass production for each crop type. By late June 2009, prairie plots had significantly more aboveground biomass than the hay and corn plots (Kruskal-Wallis, $p$-value $<0.0001$, fig. $10 \mathrm{~A}$ ); however, by mid-August, the corn plots had significantly more aboveground biomass than the hay and prairie plots (Kruskal-Wallis, $p$-value $<0.0001$, fig. $10 B$ ).

Extraction of water from soil by plants near the time of chemical application was an important factor in the movement of surface-applied solutes through soil to groundwater. Between April and June 2009, prairie plots had produced more aboveground biomass and had extracted more water from the upper $125 \mathrm{~cm}$ of the soil profile compared to all other land-cover types. A similar pattern was observed in 2008. Evapotranspiration rates of prairie peaked in June, closer to the time of chemical application, compared to August for corn. Although the cumulative soil-water losses caused by evapotranspiration and percolation below the rooting zone were similar between corn and prairie, bromide was transported to groundwater more slowly in prairie compared to corn. By 18 months after application, bromide had been detected in groundwater below all 5 replicate plots of corn, but in only 2 of 5 prairie replicate plots. Also by 18 months after application, at least 34 percent of the applied mass had leached below the rooting zone of corn, compared to 0.7 percent in prairie as determined in one plot of each land-cover type (Trost, 2010).

Differences in chemical properties (table 3 ) between SMZ, SMX, 17BE, and bromide provide some insight into the different behaviors of these chemicals in soil. Bromide was the most soluble chemical applied to the plots (table 3). Of the antibiotics added, SMX was slightly more water-soluble than SMZ, and both of these were far more water-soluble than 17BE (table 3). A related chemical property, the octanol-water 
partition coefficient $\left(\mathrm{K}_{\mathrm{ow}}\right.$, table 3$)$ indicates that $17 \mathrm{BE}$ would be most likely to adsorb to soil, followed by SMX and SMZ, then bromide. The octanol-water partition coefficient is defined as "a coefficient representing the ratio of the solubility of a compound in octanol (a nonpolar solvent) to its solubility in water (a polar solvent). The higher the $\mathrm{K}_{\mathrm{ow}}$, the more nonpolar the compound. $\log \mathrm{K}_{\mathrm{ow}}$ is generally used as a relative indicator of the tendency of an organic compound to adsorb to soil" (U.S. Environmental Protection Agency, 2013). Bromide, therefore, likely tended to partition into soil water more than the other chemicals. Based on these two chemical properties, it is reasonable to hypothesize that bromide would be transported along with soil water, and the transport of the other compounds may be slower because of adsorption to soil. This is additional evidence that the $17 \mathrm{BE}$ measured in soil water and groundwater came from a source external to the experimental treatments. Chemical properties alone do not explain why SMZ and SMX behaved differently from each other and from bromide. Further investigation into these observations is warranted.

\section{Implications}

The data collected during this plot-scale experiment provide information about the fate and transport of three compounds, SMZ, SMX, and 17BE, applied on the land surface. Little to no SMZ, SMX, or 17BE was observed in perennial (prairie, hay) or annual (corn) aboveground plant tissues even though the antibiotics, SMZ and SMX, persisted in the soil for at least 8 weeks after application. These observations indicate that only small amounts (less than 1 percent of the applied mass) of these chemicals might be removed from soil through biomass harvesting, regardless of perennial or annual land cover. Detections of SMZ in soil water and groundwater beneath perennial and annual land-cover types on sandy soils highlight the mobility and persistence of this chemical in the environment. Because SMZ was not taken up by plants in substantial quantities and was transported to groundwater in both perennial and annual land-cover types, a different strategy (other than changing vegetation from corn to prairie) might be more effective at preventing SMZ from reaching groundwater.

Quality-assurance data from chemical analysis with ELISA kits indicate that SMZ and SMX can be detected and quantified in soil, plant-tissue, and water samples if the chemicals are present at concentrations greater than a kit's minimum reporting level. With a properly designed quality-assurance plan, SMZ and SMX ELISA kits are a useful method for quantifying concentrations of these chemicals in environmental samples. Concentration data from the 17BE ELISA kits were less reliable than the SMZ and SMX kits and indicate that cross-reactivity with other chemicals in environmental samples hindered interpretation of results. A more robust analytical method is necessary for determining $17 \mathrm{BE}$ concentrations in environmental samples.
This study only focused on the parent chemicals; further research is needed to understand the degradation and transformations of these chemicals within plant tissues, soils, soil water, and groundwater. The methods used in this study were not designed to detect such altered compounds.

\section{Summary}

The U.S. Geological Survey, in cooperation with the College of Biological Sciences of the University of Minnesota and the Legislative-Citizen Commission on Minnesota Resources, initiated this study to investigate the effects of land-cover type on the fate and transport of three surface-applied chemicals of emerging concern. The antibiotics sulfamethazine (SMZ) and sulfamethoxazole (SMX) and the steroidal hormone 17-betaestradiol (17BE) were applied to the surface of five plots of each land-cover type in May 2008 and April 2009. Current (2013) practices of animal waste application to row-crop systems used for biofuel production can affect surface-water and groundwater quality. Previous research has indicated that perennial crops, such as prairies, have the potential for producing biofuel and reducing flows of water and chemicals to surface water and ground-water compared to row crops. Few studies have documented, in detail, the use of inexpensive analytical methodology for measuring antibiotics and hormones in a variety of environmental sample matrices, such as plant tissues and soils.

The experimental design included 35 plots [11 meters (m) by $11 \mathrm{~m}$ ] with land-cover types of nonvegetative bare soil, corn, hay, or prairie. Five "treatment" plots of each land-cover type (20 plots total) received applications of SMZ, SMX, 17BE, and bromide. Background levels of these chemicals in plant tissues, soil, soil water, and groundwater were determined in samples collected from bare soil, hay, and prairie control plots (15 plots total) that did not receive any chemical applications. Background levels of these chemicals in corn plants were determined in samples collected from a single large stand of corn that did not receive additions of these chemicals.

Concentrations of SMZ, SMX, and 17BE measured with enzyme-linked immunosorbent assay (ELISA) kits in planttissue, soil [0-10 centimeters $(\mathrm{cm})]$, soil-water, and groundwater samples collected between October 2008 and October 2009 were used to compare the fate and transport of these chemicals through land-cover types of bare soil and three potential biofuel cropping systems: corn, hay, and prairie.

A quality-assurance plan was implemented in support of quantitation with the ELISA kits. Multiple check standards, blanks, and spikes were analyzed with each individual ELISA kit to assess the accuracy and precision of SMZ, SMX, and 17BE quantification within and between kits. A minimum reporting level (MRL) for each ELISA kit was assigned according to a protocol that minimized false positive detections. The antibiotic SMZ was detected at concentrations 
greater than the MRL in 2 of 26 deionized water and in none of 39 organic-free laboratory and field blanks. The antibiotic SMX was not detected at concentrations greater than the MRL in any field or laboratory blanks of deionized water (42 samples) or organic-free blank water (40 samples). The hormone $17 \mathrm{BE}$ was detected at concentrations greater than the MRL in 1 of 25 laboratory deionized water blanks and 2 of 33 organic-free field blanks. Plant-tissue and soil-extract samples were analyzed as spiked-unspiked pairs to assess the yield of each chemical through the processes of extraction and ELISA analysis. The recovery of SMZ, SMX, and 17BE in spiked samples through the extraction procedure generally was higher in soil samples compared to plant-tissue samples.

The areal concentrations of SMZ, SMX, and 17BE, in milligrams per square meter $\left(\mathrm{mg} / \mathrm{m}^{2}\right)$, were compared among the land-cover treatments. Prairie plots tended to have the highest areal concentrations of SMZ and SMX in the upper $10 \mathrm{~cm}$ of soil immediately following application. Areal concentrations of SMZ in the upper $10 \mathrm{~cm}$ of soil decreased in all 5 replicate prairie treatment plots and SMX concentrations decreased in 4 of 5 replicate prairie treatment plots during 8 weeks from April 2009 to June 2009. During these same 8 weeks, prairie plots had produced more aboveground biomass and had extracted more water from the upper $125 \mathrm{~cm}$ of the soil profile compared to all other land-cover types. A consistent increasing or decreasing pattern was not observed across the replicate plots of the other land-cover types. The high root biomass in prairie plots may have contributed to the collection of soil samples in April 2009 and June 2009, which were more representative of the entire soil profile $(0-10 \mathrm{~cm})$ compared to soil samples collected from the other land-cover types. This issue of sample "representativeness" may explain the low initial SMZ and SMX soil concentrations and small concentration changes between April 2009 and June 2009 in bare soil, corn, and hay plots.

Areal concentrations of SMZ and SMX in prairie plant tissue did not explain the temporal changes in areal concentrations in soil of these chemicals. The areal concentrations of SMZ and SMX in the aboveground plant tissues in June 2009 and August 2009 were much lower, generally two to three orders of magnitude, than the areal concentrations of these chemicals in soil. Pooling all treatment plot data, the median areal concentration of SMZ and SMX in plant tissues was 0.01 and 0.10 percent of the applied chemical mass compared to 22 and 12 percent in soil, respectively. Furthermore, areal concentrations of SMZ and SMX in plant-tissue samples were variable, and did not differ significantly between control and treatment plots within each land-cover type.

Soil-water and groundwater samples collected periodically between October 2008 and October 2009 indicated that SMZ leached below the rooting zone to groundwater in all four land-cover types, whereas SMX rarely was detected in water in measurable quantities at those depths. The chemical SMZ was detected in 23 percent of soil-water samples and in 16 percent of groundwater samples collected from treatment plots. SMZ was detected most frequently in soil water beneath hay plots, followed by bare soil plots, prairie plots, and corn plots. The highest SMZ concentration, 320 nanograms per liter, was measured in the soil water from a hay plot. The chemical SMX was detected in only 1 percent of soil-water and groundwater samples collected from treatment plots.

In contrast to SMZ and SMX, 17BE was not detected reliably in soil samples. ELISA-determined 17BE concentrations in plant-tissue, soil-water, and groundwater samples indicated the presence of chemicals that were not applied as part of this experiment [17BE from an external source or other chemical(s) that interfered with the 17BE ELISA kits].

\section{References Cited}

Abraxis, 2010a, 17 beta-estradiol plate reader kit manual: accessed December 31, 2012, at http://www.abraxiskits. com/uploads/products/docfiles/61_PN580002USER.pdf.

Abraxis, 2010b, Sulfamethazine plate reader kit manual: accessed December 31, 2012, at http://www.abraxiskits. com/moreinfo/PN5101SMUSER.pdf.

Abraxis, 2010c, Sulfamethoxazole plate reader kit manual: accessed December 31, 2012, at http://www.abraxiskits. com/uploads/products/docfiles/240_PN522003USER.pdf.

Aga, D.S., Goldfish, R., and Kulshrestha, P., 2003, Application of ELISA in determining the fate of tetracyclines in landapplied livestock wastes: Analyst, v. 128, no. 6, p. 658-662.

Baker, D.G., 1958, A comparison of two evapotranspiration calculation methods and the application of one to determine some climatic differences between Great Soil Groups: Minneapolis, Minn., University of Minnesota, Ph.D. Thesis, $210 \mathrm{p}$.

Bekele, E., 2006, Impact of change in vegetation cover on groundwater recharge to a phreatic aquifer in Western Australia-Assessment of several recharge estimation techniques: Australian Journal of Earth Sciences, v. 53, no. 6, p. 905-917.

Boxall, A.B.A., Johnson, P., Smith, E.J., Sinclair, C.J., Stutt, E., and Levy, L.S., 2006, Uptake of veterinary medicines from soils into plants: Journal of Agricultural and Food Chemistry, v. 54, no. 6, p. 2288-2297.

Boxall, A.B.A., Kay, P., Blackwell, P.A., and Fogg, L.A., 2004, Fate of veterinary medicines applied to soils, in Kummerer, K., ed., Pharmaceuticals in the environmentSources, fate, effects and risks: Berlin, Springer-Verlag, p. $165-180$.

Boxall, A.B.A., Kolpin, D.W., Halling-Sorensen, B., and Tolls, J., 2003, Are veterinary medicines causing environmental risks?: Environmental Science and Technology, v. 37, no. 15 , p. $286 \mathrm{~A}-294 \mathrm{~A}$. 
Brye, K.R., Norman, J.M., Bundy, L.G., and Gower, S.T., 2000, Water-budget evaluation of prairie and maize ecosystems: Soil Science Society of America Journal, v. 64, no. 2, p. 715-724.

Campagnolo, E.R., Johnson, K.R., Karpati, A., Rubin, C.S., Kolpin, D.W., Meyer, M.T., Esteban, J.E., Currier, R.W., Smith, K., Thu, K.M., and McGeehin, M., 2002, Antimicrobial residues in animal waste and water resources proximal to large-scale swine and poultry feeding operations: Science of the Total Environment, v. 299, no. 1-3, p. 89-95.

Casey, F.X.M., Oduor, P.G., Hakk, H., Larsen, G.L., and DeSutter, T.M., 2008, Transport of 17 [beta]-estradiol and testosterone in a field lysimeter: Soil Science, v. 173, no. 7, p. $456-467$.

Cedar Creek Ecosystem Science Reserve, 2010, Experiment

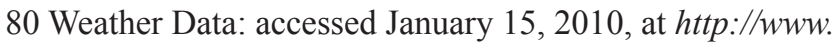
cbs.umn.edu/cedarcreek/research/weather.

Cedar Creek Ecosystem Science Reserve, 2012a, Experiment 120 Methods: accessed April 6, 2012, at http://www.cbs. umn.edu/cedarcreek/research/data.

Cedar Creek Ecosystem Science Reserve, 2012b, Experiment 141 Soil-water Content Data: accessed April 9, 2012, at http://www.cbs.umn.edu/cedarcreek/research/data.

Cedar Creek Ecosystem Science Reserve, 2012c, Experiment 84 Water Level Data: accessed April 9, 2012, at http://www. cbs.umn.edu/cedarcreek/research/data.

ChemSpider.com, 2013a, Chem Spider ID—254 Bromide: accessed August 15, 2013, at http://www.chemspider.com/ Chemical-Structure.254.html.

ChemSpider.com, 2013b, Chem SpiderID — 5136 Sulfamethazine: accessed August 15, 2013, at http://www.chemspider. com/Chemical-Structure.5136.html.

ChemSpider.com, 2013c, Chem Spider ID—5138 Sulfamethoxazole: accessed August 15, 2013, at $h t t p: / / w w w$. chemspider.com/Chemical-Structure.5138.html.

ChemSpider.com, 2013d, Chem Spider ID—5554 17-betaestradiol: accessed August 15, 2013, at http://www. chemspider.com/Chemical-Structure.5554.html.

Crisp, T.M., Clegg, E.D., Cooper, R.L., Wood, W.P., Anderson, D.G., Baetcke, K.P., Hoffmann, J.L., Morrow, M.S., Rodier, D.J., Schaeffer, J.E., and others, 1998, Environmental endocrine disruption-An effects assessment and analysis: Environmental Health Perspectives, v. 106, no. Suppl. 1, p. 11-56.

DeLiguoro, M., Cibin, V., Capolongo, F., Halling-Sørensen, B., and Montesissa, C., 2003, Use of oxytetracycline and tylosin in intensive calf farming - Evaluation of transfer to manure and soil: Chemosphere, v. 52, no. 1, p. 203-212.
Delin, G., Landon, M.K., Lamb, J.A., and Anderson, J.L., 1994, Characterization of the hydrogeology and water quality at the management systems evaluation area near Princeton, Minnesota, 1991-92: U.S. Geological Survey Water-Resources Investigations Report 94-4149, accessed August 19, 2013, at http://pubs.usgs.gov/wri/1994/4149/ report.pdf.

Delin, G.N., Healy, R.W., Landon, M.K., and Bohlke, J.K., 2000, Effects of topography and soil properties on recharge at two sites in an agricultural field: Journal of the American Water Resources Association, v. 36, no. 6, p. 1401-1416.

Delin, G.N., and Herkelrath, W.N., 2005, Use of soil moisture probes to estimate ground water recharge at an oil spill site: Journal of the American Water Resources Association, v. 41, no. 6, p. 1259-1277.

Dijkstra, F.A., West, J.B., Hobbie, S.E., Reich, P.B., and Trost, J., 2007, Plant diversity, $\mathrm{CO}_{2}$, and $\mathrm{N}$ influence inorganic and organic $\mathrm{N}$ leaching in grasslands: Ecology, v. 88, no. 2, p. 490-500. (Also available at $h t t p: / / d x . d o i . o r g / 10.1890 / 06-$ 0733.)

Dolliver, H., Kumar, K, and Gupta, S., 2007, Sulfamethazine uptake by plants from manure-amended soil: Journal of Environmental Quality, v. 36, no. 4, p. 1224-1230.

Dolliver, H., and Gupta, S., 2008a, Antibiotic losses in leaching and surface runoff from manure-amended agricultural land: Journal of Environmental Quality, v. 37, no. 3, p. 1227-1237.

Dolliver, H., and Gupta, S., 2008b, Antibiotic losses from unprotected manure stockpiles: Journal of Environmental Quality, v. 37, no. 3, p. 1238-1244.

Dolliver, H., Gupta, S., and Noll, S., 2008, Antibiotic degradation during manure composting: Journal of Environmental Quality, v. 37, no. 3, p. 1245-1253.

Dolliver, H., Kumar, K., Gupta, S., and Singh, A., 2008, Application of enzyme-linked immunosorbent assay analysis for determination of monensin in environmental samples: Journal of Environmental Quality, v. 37, no. 3, p. 1220-1226.

Erbs, M., Hoerger, C.C., Hartmann, N., and Bucheli, T.D., 2007, Quantification of six phytoestrogens at the nanogram per liter level in aqueous environmental samples using ${ }^{13} \mathrm{C}_{3}$-labeled internal standards: Journal of Agricultural and Food Chemistry, v. 55, no. 21, p. 8339-8345. (Also available at $h t t p: / / d x$. doi.org/10.1021/jf071661j.)

Erickson, M.L., 2012, Steroidal hormones and other related compounds in shallow groundwater in nonagricultural areas of Minnesota - Study design, methods, and data, 2009-10: U.S. Geological Survey Data Series 663, 9 p., accessed August 21, 2013, at http://pubs.usgs.gov/ds/663/. 
Fishman, M.J., 1993, Methods of analysis by the U.S. Geological Survey National Water Quality Laboratory-Determination of inorganic and organic constituents in water and fluvial sediments: U.S. Geological Survey Open File Report 93-125, 217 p., accessed August 21, 2013, at http://pubs. er.usgs.gov/publication/ofr93125.

Fornara, D.A., and Tilman, D., 2008, Plant functional composition influences rates of soil carbon and nitrogen accumulation: Journal of Ecology, v. 96, no. 2, p. 314-322.

Grigal, D.F., Chamberlain, L.M., Finney, H.R., Wroblewski, D.V., and Gross, E.R., 1974, Soils of the Cedar Creek Natural History Area: Agricultural Experiment Station, University of Minnesota, Misc. Report 123-1974, accessed August 21, 2013, at http://www.cbs.umn.edu/cedarcreek/ research/publications.

Hamscher, G., Pawelzick, H.T., Hoper, H., and Nau, H., 2005, Different behavior of tetracyclines and sulfonamides in sandy soils after repeated fertilization with liquid manure: Environmental Toxicology and Chemistry, v. 24, no. 4, p. $861-868$.

Hanselman, T.A.T., Graetz, D.A., and Wilkie, A.C., 2003, Manure-borne estrogens as potential environmental contaminants-A review: Environmental Science and Technology, v. 37 , no. 24 , p. $5471-5478$.

Hartig, C., Storm, T., and Jekel, M., 1999, Detection and identification of sulphonamide drugs in municipal wastewater by liquid chromatography coupled with electrospray ionisation tandem mass spectrometry: Journal of Chromatography A, v. 854, p. 163-173.

Helsel, D.R., and Hirsch, R.M., 2002, Statistical methods in water resources: U.S. Geological Survey Techniques of Water-Resources Investigations, book 4, chap. A3, 510 p., accessed August 23, 2013, at http://pubs.usgs.gov/twri/ twri4a3/.

Higgins, J.J., 2004, Introduction to modern nonparametric statistics: Pacific Grove, Calif., Brooks/Cole, 366 p.

Hirsch, R., Ternes, T., Haberer, K., and Kratz, K., 1999, Occurrence of antibiotics in the aquatic environment: Science of the Total Environment, v. 225, no. 1, p. 109-118.

Hollander, M., and Wolfe, D.A., 1973, Nonparametric statistical methods: New York, John Wiley and Sons, 503 p.

Huang, E., and Stafford, R., 2002, National patterns in the treatment of urinary tract infections in women by ambulatory care physicians: Archives of Internal Medicine, v. 162, no. 1, p. 41-47.

Iwane, T., Urase, T., and Yamamoto, K., 2001, Possible impact of treated wastewater discharge on incidence of antibiotic resistant bacteria in river water: Water Science and Technology, v. 43, no. 2, p. 91-99.
Kay, P., Blackwell, P.A., and Boxall, A.B.A., 2004, Fate of veterinary antibiotics in a macroporous tile drained clay soil: Environmental Toxicology and Chemistry, v. 23, no. 5, p. 1136-1144.

Kay, P., Blackwell, P.A., and Boxall, A.B.A., 2005, Transport of veterinary antibiotics in overland flow following the application of slurry to arable land: Chemosphere, v. 59, no. 7, p. 951-959.

Kemper, N., 2008, Veterinary antibiotics in the aquatic and terrestrial environment: Ecological Indicators, v. 8, no. 1, p. 13 .

Kjaer, J., Olsen, P., Bach, K., Barlebo, H.C., Ingerslev, F., Hansen, M., and Sørensen, B.H., 2007, Leaching of estrogenic hormones from manure-treated structured soils: Environmental Science and Technology, v. 41, no. 11, p. 3911-3917.

Kolpin, D.W., 1997, Agricultural chemicals in groundwater of the midwestern United States-Relations to land use: Journal of Environmental Quality, v. 26, no. 4, p. 1025-1037.

Kolpin, D.W., Thurman, E.M., and Linhart, S.M., 2001, Occurrence of cyanazine compounds in groundwater-Degradates more prevalent than the parent compound: Environmental Science and Technology, v. 35, no. 6, p. 1217-1222.

Kolpin, D., and Furlong, E., 2002, Pharmaceuticals, hormones, and other organic wastewater contaminants in US streams, 1999-2000 - A national reconnaissance: Environmental Science and Technology, v. 36, no. 6, p. 1202-1211.

Kuhnle, G.G.C., Dell'Aquila, C., Aspinall, S.M., Runswick, S.A., Mulligan, A.A., and Bingham, S.A., 2008, Phytoestrogen content of beverages, nuts, seeds, and oils: Journal of Agricultural and Food Chemistry, v. 56, no. 16, p. 7311-7315.

Kumar, K., Thompson, A., Singh, A.K., Chander, Y., and Gupta, S.C., 2004, Enzyme-linked immunosorbent assay for ultratrace determination of antibiotics in aqueous samples: Journal of Environmental Quality, v. 33, no. 1, p. 250-256.

Kummerer, K., 2004a, Resistance in the environment, in Kummerer, K. ed., Pharmaceuticals in the environmentSources, fate, effects and risks: Berlin, Springer-Verlag, p. 223-231.

Kummerer, K., ed., 2004b, Pharmaceuticals in the environment-Sources, fate, effects and risks: Berlin, SpringerVerlag, $527 \mathrm{p}$.

Kung, K.J.S., 1990, Influence of plant uptake on the performance of bromide tracer: Soil Science Society of America Journal, v. 54, no. 4, p. 975-979. 
Lai, K.M., Johnson, K.L., Scrimshaw, M.D., and Lester, J.N., 2000, Binding of waterborne steroid estrogens to solid phases in river and estuarine systems: Environmental Science and Technology, v. 34, no. 18, p. 3890-3894.

Lee, K.E., Barber, L.B., Furlong, E.T., Cahill, J.D., Kolpin, D.W., Meyer, M.T., and Zaugg, S.D., 2004, Presence and distribution of organic wastewater compounds in wastewater, surface, ground, and drinking waters, Minnesota, 2000-02: U.S. Geological Survey Scientific Investigations Report 2004-5138, 47 p., accessed August 20, 2013, at http://pubs.usgs.gov/sir/2004/5138/.

Levy, S.B., 1998, The challenge of antibiotic resistance: Scientific American, v. 278, no. 3, p. 46-53.

Lindholm, G.F., 1980, Ground-water appraisal of sand plains in Benton, Sherburne, Stearns, and Wright Counties, central Minnesota: U.S. Geological Survey Open-File Report 80-1285, 111 p., accessed August 21, 2013, at http://pubs. er.usgs.gov/publication/ofr801285.

Liu, Z., Kanjo, Y., and Mizutani, S., 2010, A review of phytoestrogens-Their occurrence and fate in the environment: Water Research, v. 44, no. 2, p. 567-77.

Mellon, M., Benbrook, C., and Benbrook, K., 2001, Hogging it!-Estimates of antimicrobial abuse in livestock: accessed April 12, 2012, at http://www.ucsusa.org/food_and_ agriculture/our-failing-food-system/industrial-agriculture/ hogging-it-estimates-of.html.

Miller, K.J., and Meek, J., 2006, Helena Valley ground water-Pharmaceuticals, personal care products, endocrine disruptors (PPCPs) and microbial indicators of fecal contamination: Montana Bureau of Mines and Geology Open-

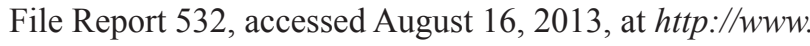
mbmg.mtech.edu/pdf-open-files/mbmg532-helenavalley.pdf.

Minnesota Department of Health/Minnesota Geological Survey, 2013, Minnesota County Well Index Online: accessed August 14, 2013, at http://www.health.state.mn.us/divs/eh/ cwi/.

Minnesota Pollution Control Agency, 2012, Manure application rate guide: accessed December 31, 2012, at $h t t p: / / w w w$. pca.state.mn.us/index.php/view-document.html?gid=3534.

Natural Resources Conservation Service, 2007, Establishment of introduced grasses and legumes: Biology Jobsheet no. 8, accessed August 15, 2007, at http://efotg.sc.egov.usda.gov/ references/public/MN/IntroducedGrassLegumes.pdf.

Natural Resources Conservation Service, 2010, National Water and Climate Center: Climatic Data for TAPS Station,

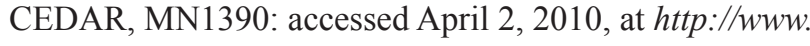
wcc.nrcs.usda.gov/ftpref/support/climate/taps/mn/27003.txt.
Price, K.R., and Fenwick, G.R., 1985, Naturally occurring oestrogens in foods-A review: Food Additives and Contaminants, v. 2, no. 2, p. 73-106.

R Development Core Team, 2011, R-A language and environment for statistical computing: Vienna, Austria, R Foundation for Statistical Computing. (Also available at $h t t p: / / R$ project.org/.)

Rachman, A., Anderson, S.H., Gantzer, C.J., and Albert, E.E., 2004, Soil hydraulic properties influenced by stiff-stemmed grass hedge systems: Soil Science Society of America Journal, v. 68, no. 4, p. 1386-1393.

Randall, G.W., Huggins, D.R., Russelle, M.P., Fuchs, D.J., Nelson, W.W., and Anderson, J.L., 1997, Nitrate losses through subsurface tile drainage in Conservation Reserve Program, alfalfa, and row crop systems: Journal of Environmental Quality, v. 26, no. 5, p. 1240-1247.

Raven, P.E., Evert, R.F., and Eichhorn, S.E., 1999, Biology of plants: New York, W.H. Freeman and Company, 944 p.

Reinle, K., and Block, G., 1996, Phytoestrogen content of foods-A compendium of literature values: Nutrition and Cancer, v. 26, p. 123-148.

Schilling, K.E., Jha, M.K., Zhang, Y.-K., Gassman, P.W., and Wolter, C.F., 2008, Impact of land use and land cover change on the water balance of a large agricultural watershed-Historical effects and future directions: Water Resources Research, v. 44, no. 7, p. 1-12.

Schuh, M.C., Casey, F.X.M., Hakk, H., DeSutter, T.M., Richards, K.G., Khan, E., and Oduor, P.G., 2011, Effects of field-manure applications on stratified 17ß-estradiol concentrations: Journal of Hazardous Materials, v. 192, no. 2, p. $748-752$.

Seastedt, T.R., 1985, Canopy interception of nitrogen in bulk precipitation by annually burned and unburned tallgrass prairie: Oecologia, v. 66, no. 1, p. 88-92.

Sigma Aldrich, 1997, Product information sheet for beta-estradiol, product number E8875: accessed August 16, 2013, at http://www.sigmaaldrich.com/content/dam/sigma-aldrich/ docs/Sigma/Product_Information_Sheet/e8875pis.pdf.

Sokal, R.R., and Rohlf, F.J., 1995, Biometry-The principles and practice of statistics in biological research: New York, W.H. Freeman, 887 p.

Swartz, C.H., Reddy, S., Benotti, M.J., Yin, H., Barber, L.B., Brownawell, B.J., and Rudel, R.A., 2006, Steroid estrogens, nonylphenol ethoxylate metabolites, and other wastewater contaminants in groundwater affected by a residential septic system on Cape Cod, MA: Environmental Science and Technology, v. 40, no. 16, p. 4894-4902. 
Thermo Fisher Scientific Incorporated, 2008, User guideBromide ion selective electrode: accessed August 16, 2013, at https://static.thermoscientific.com/images/D17161 .pdf.

Thiele-Bruhn, S., 2003, Pharmaceutical antibiotic compounds in soils-A review: Journal of Plant Nutrition and Soil Science, v. 166 , no. 2, p. 145-167.

Thompson, M.L., Casey, F.X.M., Khan, E., Hakk, H., Larsen, G.L., and Desutter, T., 2009, Occurrence and pathways of manure-borne $17 \beta$-estradiol in vadose zone water: Chemosphere, v. 76, no. 4, p. 472-479 (Also available at http:// dx.doi.org/10.1016/j.chemosphere.2009.03.037.)

Tilman, David, Hill, J., and Lehman, C., 2006, Carbonnegative biofuels from low-input high-diversity grassland biomass: Science, v. 314, no. 5805, p. 1598-1600.

Tilman, David, Reich, P.B., and Knops, J.M.H., 2006, Biodiversity and ecosystem stability in a decade-long grassland experiment: Nature, v. 441, no. 7093, p. 629-632.

Timme, P.J., 1995, National Water Quality Laboratory 1995 services catalog: U.S. Geological Survey Open-File Report 95-352, p. 92. (Also available at http://pubs.usgs.gov/ of/1995/0352/report.pdf.)

Tolls, J., 2001, Sorption of veterinary pharmaceuticals in soils-A review: Environmental Science and Technology, v. 35 , no. 17 , p. $3397-3406$.

Trost, J.J., 2010, Effects of perennial and annual vegetation on a soil water balance and groundwater recharge: Minneapolis, University of Minnesota, M.S. thesis, accessed June 1, 2012, at http://purl.umn.edu/93517.

U.S. Environmental Protection Agency, 1996, Method 9211 potentiometric determination of bromide in aqueous samples with ion-selective electrode, revison 0: accessed March 23, 2010, at http://www.epa.gov/epawaste/hazard/ testmethods/sw846/pdfs/9211.pdf.
U.S. Environmental Protection Agency, 2013, Underground storage tanks glossary of technical terms: accessed August 15, 2013, at http://www.epa.gov/oust/cat/tumgloss. htm\#o.

U.S. Geological Survey, variously dated, National field manual for the collection of water-quality data: U.S. Geological Survey Techniques of Water-Resources Investigations, book 9, chaps. A1-A9, accessed August 16, 2013, at http:// pubs.water.usgs.gov/twri9A.

U.S. Geological Survey, 2013a, Quality control at the U.S. Geological Survey's National Water Quality Laboratory: accessed August 21, 2013, at http://nwql.usgs.gov/quality. shtml.

U.S. Geological Survey, 2013b, National Water Information System (NWISWeb): U.S. Geological Survey database, accessed August 21, 2013, at http://waterdata.usgs.gov/ nwis.

Weber, A., Fohrer, N., and Moller, D., 2001, Long-term land use changes in a mesoscale watershed due to socio-economic factors-Effects on landscape structures and functions: Ecological Modelling, v. 140, no. 1-2, p. 125-140.

Worrall, F., Besien, T., and Kolpin, D.W., 2002, Groundwater vulnerability - Interactions of chemical and site properties: Science of the Total Environment, v. 299, no. 1-3, p. 131-143.

Wuest, S.B., Williams, J.D., and Gollany, H.T., 2006, Tillage and perennial grass effects on ponded infiltration for seven semi-arid loess soils: Journal of Soil and Water Conservation, v. 61 , no. 4, p. 218-223. 
Appendixes 


\section{Appendix 1. Soil-Temperature and Soil-Water Content Data}

Soil-temperature and volumetric soil-water content measurements were made with Campbell Scientific ${ }^{\circledR}$ 107-L and CS616 TDR sensors, respectively, at 25, 50, 100, 150, and 200 centimeters below land surface in four plots: 204 (corn), 217 (prairie), 254 (hay), and 276 (bare soil). The entire continuous dataset from March 2008 through December 2009 is available in tables 1-1, 1-2, and 1-3. Table 1-1 is a Microsoft Excel file (http://pubs.usgs.gov/ sir/2013/5202/downloads/Table1-1_to_1-2.xlsx) that provides metadata for each column in table 1-3 (http://pubs.usgs.gov/sir/2013/5202/downloads/Table1-3.txt). Table 1-2 is a Microsoft Excel file (http://pubs.usgs.gov/sir/2013/5202/downloads/Table1-1_to_1-2.xlsx) that describes coding used to qualify data values in table 1-3 (http://pubs.usgs.gov/sir/2013/5202/ downloads/Table1-3.txt). Table 1-3 is a comma-separated file containing the soil-temperature and volumetric soil-water content data. Additional details about field operations and data processing are provided in Trost (2010).

\section{Appendix 2. Groundwater-Level Data}

A continuous groundwater-level record for the water-table well in plot 254 (table 1; fig. 2) from March 2008 through December 2009 is available in a Microsoft Excel spreadsheet (.xlsx format) (http://pubs.usgs.gov/sir/2013/5202/downloads/Tables2-1_to_2-4. $x l s x)$. There are four worksheets in this file: "Table2-1_Readme," "Table2-2_GWSiteInformation," "Table2-3_GWDataCodeDescriptions," and "Table2-4_GroundwaterData." The "Table2-1_Readme" worksheet (table 2-1) provides metadata for each column in tables $2-2,2-3$, and 2-4. The "Table2-2_GWSiteInformation" worksheet (table 2-2) contains well construction and installation details. The "Table2-3_GWDataCodeDescriptions" worksheet (table 2-3) describes a code associated with each plot 254 water-level data point. The "Table2-4_GroundwaterData" worksheet (table 2-4) contains the groundwater-level data record for plot 254. Original data for another well, BG3, are also presented in this table but have not been corrected. Additional details about field operations and data processing are available in Trost (2010). 


\section{Appendix 3. Detailed Methods and Data for Sulfamethazine, Sulfamethoxazole, and 17-beta-Estradiol}

This appendix describes methods for determining chemical concentrations for this study using enzyme-linked immunosorbent assay (ELISA) kits. Specifically, calibration procedures and laboratory methods for the ELISA kits are described.

\section{ELISA Kit Calibration Procedure}

Sulfamethazine (SMZ), sulfamethoxazole (SMX), and 17-beta-estradiol (17BE) concentrations in aboveground plant-tissue, soil, soil-water, and groundwater samples were determined with ELISA kits purchased from Abraxis, LLC, Warminster, Pennsylvania (product numbers 515001, 522003, 580002, respectively). All stored environmental samples were thawed and allowed to come to room temperature before ELISA analysis. No more than 80 samples were analyzed per any one calibration series. Each standard, control, and environmental sample was analyzed in duplicate. Kit-specific calibration curves were calculated with a least-squares regression procedure, which related the observed relative percent absorbance (eq. 1) to the expected concentrations of manufacturer-provided calibration standards. A detailed error analysis of the concentrations predicted from regression coefficients in equations 10,12, and 14 was beyond the scope of this report. Because the error term, $e_{i}$, in each regression model (equations 9,11 , and 13) was not necessarily identically or normally distributed, confidence intervals of the predicted concentrations could not be determined (Helsel and Hirsch, 2002).

Sulfamethazine (SMZ) concentrations were determined with Abraxis ELISA magnetic particle kits (product number 515001) capable of detecting SMZ in the range of 50 to 5,000 nanograms per liter $(\mathrm{ng} / \mathrm{L})$. The following paragraph is a summary of the laboratory procedure and principle of operation provided with each SMZ Abraxis kit (Abraxis, 2010b).

Unless specified otherwise, the reagents were supplied with the Abraxis kits. Separate test tubes received 250 microliters $(\mu \mathrm{L})$ of each standard, control, or environmental sample to be tested. Each test tube then received $250 \mu \mathrm{L}$ of a buffered solution containing horseradish peroxidase-labeled sulfamethazine analog (SMZ Enzyme Conjugate) and $500 \mu \mathrm{L}$ of a buffered solution containing suspended paramagnetic particles covalently bound to an SMZ antibody (rabbit anti-SMZ). Each test tube was vortexed for 1 to 2 seconds. A competitive reaction took place between the SMZ in the sample and the enzyme-labeled SMZ for the antibody binding sites on the magnetic particles. The reaction was allowed to continue for 30 minutes at room temperature. The test tubes were then placed in a magnetic separator plate for 2 minutes, decanted, and blotted gently on a paper towel to remove liquid from the wells that would interfere with subsequent procedures. The sample SMZ and the enzyme-labeled SMZ were held in the test tube by the magnetic field of the plate, allowing unbound reagents to be decanted. The magnetic particles remaining in the test tube were washed twice with 1 milliliter $(\mathrm{mL})$ of preserved deionized water. During each wash step, the test tubes remained in the separator plate for 2 minutes and were then decanted and blotted as before. The presence of SMZ, now attached to the magnetic particles, was detected by the addition of $500 \mu \mathrm{L}$ of color solution containing the enzyme substrate, hydrogen peroxide, and the chromogen, 3,3',5,5'-tetramethylbenzidine. The enzyme-labeled SMZ bound to the SMZ antibody catalyzed the conversion of the substrate/chromogen mixture to a colored product. Because the labeled SMZ (conjugate) was in competition with the unlabeled SMZ (sample) for the antibody sites, the color that developed was inversely proportional to the concentration of SMZ in the sample. After the color solution was added, the test tubes were vortexed for 2 seconds and incubated at room temperature for 20 minutes. The color development was stopped with the addition of $500 \mu \mathrm{L}$ of Abraxis acid reagent. Within 15 minutes of stopping the color development, the absorbance at 450 nanometers $(\mathrm{nm})$ was measured on an Ohmicron RPA-1 Analyser (Newtown, Pa.).

Sample SMZ concentrations, in nanograms per liter (ng/L), were predicted from absorbance measurements with kit-specific calibration curves. The relative percent absorbance $\left(A_{r}\right)$ was calculated for each sample according to equation 1. The calibration curve for each kit was determined from a linear regression that related the observed percent absorbance values $\left(A_{r}\right)$ to the expected calibration standard concentrations $\left(\left[x_{l, S M Z, e}\right]\right)$ according to the model:

$$
A_{r_{i}}=b+m \times \ln \left(\frac{\frac{\left[x_{l, S M Z, e}\right]}{1,000}}{\left(100-\frac{\left[x_{l, S M Z, e}\right]}{1,000}\right)}\right)+e_{i}
$$

where

$A_{r_{i}} \quad$ is the relative percent absorbance for standard $i$ computed in equation 1 ;

$b \quad$ is the intercept of linear regression model;

$m$ is the slope of linear regression model;

$\left[x_{l, S M Z, e}\right] \quad$ is the expected SMZ standard concentrations of $i=50,500$, and 5,000 nanograms per liter; and

$e_{i} \quad$ is the independent random error for observation of standard $i$. 
Sample concentrations of SMZ $\left(\left[\hat{x}_{l, S M Z}\right]\right)$ were then predicted according to the re-arranged calibration equation:

$$
\left[\hat{x}_{l, S M Z}\right]=1,000 \times \exp \left(\frac{\left(\ln \left(\frac{A_{r}}{\left(100-A_{r}\right)}\right) \hat{b}\right)}{\hat{m}}\right)
$$

where

$$
\begin{aligned}
{\left[\hat{x}_{l, S M X}\right] } & \begin{array}{c}
\text { is the predicted sample SMZ concentration, in } \\
\text { nanograms per liter; }
\end{array} \\
\exp & \text { is the base of the natural logarithm; } \\
\hat{b} & \text { is the intercept determined from linear } \\
& \text { regression in equation } 9 ; \\
\hat{m} & \begin{array}{c}
\text { is the slope determined from linear regression } \\
\text { in equation 9; and }
\end{array} \\
A_{r} & \begin{array}{c}
\text { is the observed relative percent absorbance of } \\
\text { sample, computed in equation } 1 .
\end{array}
\end{aligned}
$$

Sulfamethoxazole (SMX) concentrations were determined with Abraxis ELISA microtiter plate kits (product number 522003) capable of detecting SMX in concentrations in the range of 15 to $1,000 \mathrm{ng} / \mathrm{L}$. The following paragraph is a summary of the laboratory procedure and principle of operation provided with each SMX Abraxis kit (Abraxis, 2010c).

Unless specified otherwise, the reagents were supplied with the Abraxis kits. Seventy-five $\mu \mathrm{L}$ of each sample, standard, or control to be tested were pipetted into separate microtiter wells coated with goat anti-rabbit antibody. Fifty $\mu \mathrm{L}$ of SMX antibody solution were added successively to each well. The well plate was covered, mixed for 30 seconds, and incubated at ambient room temperature for 20 minutes. After the incubation, $50 \mu \mathrm{L}$ of SMX enzyme conjugate solution was added successively to each well. The well plate was covered, mixed for 30 seconds, and incubated at ambient room temperature for 40 minutes. During the incubation, a competitive reaction took place between SMX in the sample (if present) and the enzyme-labeled SMX analog for the antibody binding sites on the microtiter well. After the incubation, the solution was poured out of the wells. The wells were then rinsed three times with $250 \mu \mathrm{L}$ of dilute wash buffer. Color solution $(150 \mu \mathrm{L})$ containing the enzyme substrate, hydrogen peroxide, and the chromogen, 3,3',5,5'-tetramethylbenzidine, was added successively to each well. The well plate was covered, mixed for 30 seconds, and incubated at ambient temperature for 30 minutes. During this incubation, the enzyme-labeled SMX bound to the SMX antibody catalyzed the conversion of the substrate/chromogen mixture to a colored product. Because the labeled SMX (conjugate) was in competition with the unlabeled SMX (sample) for the antibody sites, the intensity of the color developed was inversely proportional to the concentration of SMX present in the sample. After 30 minutes, the color reaction was stopped with the addition of $100 \mu \mathrm{L}$ of Abraxis acid reagent. Within 15 minutes, the absorbance at $450 \mathrm{~nm}$ was then determined for each well using a Dynatech Laboratories MRX microplate reader.
Sample SMX concentrations were predicted from raw absorbance measurements with kit-specific calibration curves. The relative percent absorbance $\left(A_{r}\right)$ was calculated for each sample according to equation 1 . The calibration curve for each kit was calculated from a nonlinear least-squares regression that related the observed percent absorbance values $\left(A_{r}\right)$ to the expected calibration standard concentrations $\left(\left[x_{l, S M X, e}\right]\right)$ according to the four-parameter model:

$$
A_{r_{i}}=\frac{(B-E)}{\left(1+\left(\frac{\left[x_{i, S W X, e}\right]}{1,000 D}\right)^{C}\right)}+E+e_{i}
$$

where

$A_{r_{i}} \quad$ is the relative percent absorbance for standard $i$ computed in equation 1 ;

$B, C, D, E \quad$ are the parameters estimated with nonlinear least squares regression;

$\left[x_{l, S M X, e}\right] \quad$ is the expected SMX standard concentrations of $i=25,50,100,250$, and 1,000

nanograms per liter; and

$e_{i} \quad$ is the independent random error for observation of standard $i$.

Sample SMX concentrations ( $\left[\hat{x}_{l, S M X}\right]$ ) were then predicted according to the re-arranged calibration equation:

$$
\left[\hat{x}_{l, S M X}\right]=1,000 \times \hat{D} \times\left(\frac{\left(\hat{B}-A_{r}\right)}{\left(A_{r}-\hat{E}\right)}\right)^{\left(\frac{1}{C}\right)}
$$

where

$$
\begin{aligned}
{\left[\hat{x}_{l, S M X}\right] } & \begin{array}{c}
\text { is the predicted sample SMX concentration, in } \\
\text { nanograms per liter; }
\end{array} \\
\hat{B}, \hat{C}, \hat{D}, \hat{E} \quad \begin{array}{l}
\text { are the parameters estimated in equation 11; } \\
\text { and }
\end{array} & \begin{aligned}
\text { is the observed relative percent absorbance of } \\
\text { sample, computed in equation } 1 .
\end{aligned}
\end{aligned}
$$

17-beta-estradiol (17BE) concentrations $\left(\left[\hat{x}_{l, 17 B E}\right]\right)$ were determined with Abraxis ELISA magnetic particle kits (product number 580002) capable of detecting 17BE concentrations in the range of $2.5 \mathrm{ng} / \mathrm{L}$ to $25 \mathrm{ng} / \mathrm{L}$. The following paragraph is a summary of the laboratory procedure and principle of operation provided with each 17BE Abraxis kit (Abraxis, 2010a).

Unless specified otherwise, the reagents were supplied with the Abraxis kits. Separate test tubes received $250 \mu \mathrm{L}$ of each standard, control, or environmental sample to be tested. Each tube then received $500 \mu \mathrm{L}$ of estradiol antibody-coupled paramagnetic particles, was vortexed for 2 seconds, and incubated at room temperature for 30 minutes. Each tube then received $250 \mu \mathrm{L}$ of estradiol enzyme conjugate, was vortexed for 2 seconds, and incubated for 90 minutes at room temperature. During this incubation, a competitive reaction took place between the estradiol that may have been in the sample and 
the enzyme-labeled estradiol for the antibody binding sites on the magnetic particles. The test tubes were then placed in a magnetic separator plate for 2 minutes, decanted, and blotted gently on a paper towel to remove liquid from the wells that would interfere with subsequent procedures. The sample $17 \mathrm{BE}$ and the enzyme-labeled 17BE were held in the test tube by the magnetic field of the plate, allowing unbound reagents to be decanted. The magnetic particles remaining in the test tube were washed twice with $1 \mathrm{~mL}$ of preserved deionized water. During each wash step, the test tubes remained in the separator plate for 2 minutes and were then decanted and blotted as before. The presence of $17 \mathrm{BE}$, now attached to the magnetic particles, was detected by the addition of $500 \mu \mathrm{L}$ of color solution containing the enzyme substrate, hydrogen peroxide, and the chromogen, 3,3',5,5'-tetramethylbenzidine. The enzyme-labeled 17BE bound to the 17BE antibody catalyzed the conversion of the substrate/chromogen mixture to a colored product. Because the labeled 17BE (conjugate) was in competition with the unlabeled 17BE (sample) for the antibody sites, the color developed was inversely proportional to the concentration of $17 \mathrm{BE}$ in the sample. After the color solution was added, the test tubes were vortexed for 2 seconds and incubated at room temperature for 20 minutes. The color development was stopped with the addition of $500 \mu \mathrm{L}$ of dilute acid. Within 15 minutes of stopping the color development, the absorbance at $450 \mathrm{~nm}$ was measured on an Ohmicron RPA-1 Analyser (Newtown, Pa.).

Sample 17BE concentrations were predicted from absorbance measurements with kit-specific calibration curves. The relative percent absorbance $\left(A_{r}\right)$ was computed for each sample in equation 1 . The calibration curve for each kit was calculated in a similar manner as the SMZ magnetic particle kits, according to the model:

$$
A_{r_{i}}=b+m \times \ln \left(\frac{\frac{\left[x_{l, 17 B E, e}\right]}{1,000}}{\left(100-\frac{\left[x_{l, 17 B E, e}\right]}{1,000}\right)}\right)+e_{i}
$$

where

$$
\begin{aligned}
A_{r_{i}} & \text { is the relative percent absorbance for } \\
& \text { standard } i \text { computed in equation 1; } \\
b & \text { is the intercept of linear regression model; } \\
m & \text { is the slope of linear regression model; } \\
\left.x_{l, 17 B E, e}\right] & \text { is the expected 17BE standard concentrations } \\
& \text { of } i=2.5,7.5, \text { and } 25 \text { nanograms per liter; } \\
\text { and } & \text { is the independent random error for } \\
e_{i} & \text { observation of standard } i .
\end{aligned}
$$

Sample concentrations of 17BE $\left(\left[\hat{x}_{l, 17 B E}\right]\right)$ were then predicted according to the re-arranged calibration equation:

$$
\left[\hat{x}_{l, 17 B E}\right]-1,000 \times \exp ^{\left(\frac{\ln \left(\frac{A_{r}}{\left(100-A_{r}\right)}\right)-\hat{b}}{\hat{m}}\right)}
$$

where

$$
\begin{array}{cl}
{\left[\hat{x}_{l, 17 B E}\right] \quad} & \text { is the predicted sample 17BE concentration, } \\
& \text { in nanograms per liter; } \\
\exp & \text { is the base of the natural logarithm; } \\
\hat{b} & \text { is the intercept determined from linear } \\
& \text { regression in equation 13; } \\
\hat{m} \quad \text { is the slope determined from linear regression } \\
\text { in equation 13; and } \\
A_{r} \quad \text { is the observed relative percent absorbance of } \\
\text { sample, computed in equation } 1 .
\end{array}
$$

\section{Detailed ELISA Laboratory Procedures}

Several check standards were analyzed in each ELISA kit to assess the accuracy and precision of SMZ, SMX, and 17BE quantification within and between kits. These standard samples included at least one laboratory deionized water blank, a mid-range "kit control" check standard from Abraxis, and laboratory-generated low-range and high-range check standards (table 4). The inclusion of laboratory-generated check standards provided information about the method performance across all ELISA kits used for each chemical. Summaries of all quality-assurance sample determinations for each chemical are presented in figure 4 and table 5 .

The laboratory-generated low-range and high-range check standards were derived from high-concentration, 1 gram per liter $(\mathrm{g} / \mathrm{L})$, standard solutions at the USGS Organic Geochemistry Research Laboratory in Lawrence, Kansas. The 1 -g/L standard solutions were made by weighing 10 to 25 milligrams (mg) of each chemical on a microbalance and dissolving it into 10 to $25 \mathrm{~mL}$ of methanol, respectively (Michael Meyer, U.S. Geological Survey, oral commun., December 2008). An aliquot of each $1-\mathrm{g} / \mathrm{L}$ standard solution was then diluted with methanol to a concentration of 1 milligram per liter $(\mathrm{mg} / \mathrm{L})$. Aliquots of the 1-mg/L standard solution of each of chemical (SMZ, SMX, and 17BE) were then diluted with organic-free blank water to the appropriate check standard concentrations (as listed in table 4). All methanol stock solutions were stored in glass amber bottles wrapped in aluminum foil at -17 degrees Celsius $\left({ }^{\circ} \mathrm{C}\right)$. The low-level and high-level standards made in the laboratory were stored in glass amber bottles wrapped in aluminum foil. The mid-range control standard was stored in the manufacturer's packaging. All of the check standards were stored at approximately $4^{\circ} \mathrm{C}$.

A citric acid buffer solution acidic solvent, 50-percent methanol and 50-percent $0.3-$ molar (M) citric acid at $\mathrm{pH} 6$ by volume, was added to the dried, homogenized plant-tissue and soil samples to extract SMZ, SMX, and 17BE from the solid matrices. The $0.3 \mathrm{M}$ citric acid solution was made by dissolving anhydrous citric acid powder (99.5-percent minimum purity, GFS Chemicals, Incorporated, Powell, Ohio, item 649) in 1 liter (L) of orgranic-free blank water purchased from the U.S. Geological Survey National Water Quality Laboratory. The $\mathrm{pH}$ of the citric acid solution was raised to 
6 (plus or minus 0.05 standard units) through the addition of sodium hydroxide $(\mathrm{NaOH})$ pellets (Fisher Scientific part S318, 97.0-percent minimum purity). One liter of methanol (Fisher Scientific part A456, optima liquid chromatography/mass spectrometry [LC/MS] grade, 99.9-percent minimum purity) was then added to the citric acid solution, which was stirred until used for extraction.

Forty milliliters of citric acid buffer, heated to $35^{\circ} \mathrm{C}$, was pipetted into each volatile organic analysis (VOA) vial that contained dried soil or plant tissue. The samples were mixed on a vortex mixer for 30 seconds and then placed in a $40{ }^{\circ} \mathrm{C}$ water bath for 1 hour. The samples were then vortexed for 30 seconds and slowly rotated end-over-end for 1 hour. The vortexing, heating, and rotating steps were then repeated a second time. The extraction slurry was then poured from the VOA vial into a plastic centrifuge tube and centrifuged at 3,800 rotations per minute (rpm) for 10 minutes. The supernatant was pipetted into a plastic syringe and filtered through a 0.45 -micron Durapore ${ }^{\mathrm{TM}}$ polyvinylidene fluoride membrane into a new, clean 40-mL VOA vial. The filtered samples were then placed in a Zymark TurboVap LVTM, heated to $40^{\circ} \mathrm{C}$, and evaporated under nitrogen gas to remove the methanol from the final filtered extract. The total volume of extract solution $\left(V_{e}\right)$ was calculated according to the following equation:

$$
V_{e}=V_{e, e v}+\left(\left(V_{e, p l}-V_{e, p e v}\right) \times \frac{V_{e, e v}}{V_{e, p e v}}\right)
$$

where

$$
\begin{aligned}
& V_{e, e v} \quad \text { is the volume of extract solution in the VOA } \\
& V_{e, p l} \quad \text { is the volume of extract solution in the plastic } \\
& \text { extraction vial, in milliliters; and } \\
& V_{e, p e v} \quad \text { is the volume of extract solution in the VOA } \\
& \text { vial before evaporation, in milliliters. }
\end{aligned}
$$

The first term $\left(V_{e, e v}\right)$ in equation 15 accounts for the solution volume in the VOA vial after evaporation, the solution from which a concentration was determined with ELISA. The second term in this equation, $\left(\left(V_{e, p l}-V_{e, p e v}\right) \times \frac{V_{e, e v}}{V_{e, p e v}}\right)$, accounts for the solution volume (and chemical mass) lost in the transfer from the plastic extraction vial to the final glass vial. Because the volume was lost before evaporation, the difference is multiplied by the ratio of post-evaporation to pre-evaporation volume to get the volume in terms of post-evaporation. Changes in the extract volume of each sample caused by spike addition, transfers between vials, and evaporation were documented by measuring changes in mass and converting the mass loss or gain to volume, as described below. Each solution volume in equations 3,4 , and 15 was computed with measurements of mass and density according to the following equation:

$$
V_{l}=\frac{m_{l}}{\rho_{l}}
$$

where

$$
\begin{array}{cl}
V_{l} & \text { is the volume of liquid sample } l, \text { in milliliters; } \\
m_{l} & \text { is the mass of liquid sample } l \text {, in grams; and } \\
\rho_{l} & \text { is the mean density of liquid sample } l \text {, in } \\
\text { grams per milliliter. }
\end{array}
$$

The mass of solution in vials was measured at each transfer and evaporation step. The mean solution density $\left(\rho_{l}\right)$ was determined for two solution types - the 50:50 methanol:citric acid buffer solution and the post-evaporation extract solution. The mean density of each solution was determined from measurements of mass of 10 aliquots of known volume. The same two mean density values were used in equations 3,4 , and 15 for every extract sample. The filtered extract solution was stored at $-17^{\circ} \mathrm{C}$ until analysis for SMZ, SMX, and 17BE with ELISA kits could be completed.

Soil-water and groundwater samples were not diluted or extracted before analysis. Aliquots from plant- and soil-extract solutions were diluted $1: 2,1: 10,1: 20,1: 50$, or $1: 100$ so that matrix interference was minimized and detections were within the SMZ and SMX kit ranges. Aliquots from plant-extract and soil-extract solutions were diluted 1:500 before 17BE ELISA analysis. Diluent provided with each Abraxis kit was used to dilute the samples. 


\section{Appendix 4. Concentration Data}

The concentration data for sulfamethazine (SMZ), sulfamethoxazole (SMX), 17-beta-estradiol (17BE), and bromide measured in samples collected at Cedar Creek Ecosystem Science Reserve (CCESR) are available in a Microsoft Excel spreadsheet (.xlsx format) at http://pubs.usgs.gov/ sir/2013/5202/downloads/Tables4-1 to 4-5.xlsx. There are five worksheets within this file. The concentrations of SMZ, SMX, and 17BE in plant-tissue, soil, soil-water, and groundwater samples analyzed with enzyme-linked immunosorbent assay (ELISA) kits are in table 4-1. The concentrations of SMZ, SMX, and 17BE in field, filter, and laboratory blank samples associated with sample processing that were analyzed with ELISA kits are in table 4-2.

The individual data values for internal lab assessments of ELISA kit performance, including Abraxis-supplied calibration standards, laboratory-generated check standards, Abraxissupplied check standards, laboratory-generated spikes, and laboratory-generated blanks (deionized water, organic-free water, and citric acid extract buffer) that were analyzed with each kit run are not included in table 4-2; however, these internal lab quality-assurance data are summarized along with the field and sample processing quality-assurance data in figures 4 and 5 and tables 5, 6, and 7 .

The concentrations of bromide tracer in soil-water and groundwater samples analyzed at the U.S. Geological Survey National Water Quality Laboratory using laboratory code 3166 (Fishman, 1993) or analyzed with a bromide ion-specific electrode are in table 4-3. The concentrations of bromide tracer in soil-water and groundwater field and replicate samples analyzed at U.S. Geological Survey National Water Quality Laboratory using laboratory code 3166 (Fishman, 1993) or analyzed with a bromide ion-specific electrode are in table 4-4. The concentrations of bromide tracer in blank and spike samples analyzed at U.S. Geological Survey National Water Quality Laboratory using laboratory code 3166 (Fishman, 1993) or analyzed with a bromide ion-specific electrode are in table 4-5. 
Publishing support provided by the: Rolla Publishing Service Center

For more information concerning this publication, contact: Director, USGS Minnesota Water Science Center 2280 Woodale Drive

Mounds View, Minnesota 55112

(763) 783-3100

Or visit the Minnesota Water Science Center Web site at: http://mn.water.usgs.gov/ 

